\title{
APPLICATION OF GEOPHYSICAL METHODS TO THE DELINEATION OF PALEOCHANNELS AND MISSING CONFINING UNITS ABOVE THE CASTLE HAYNE AQUIFER AT U.S. MARINE CORPS AIR STATION, CHERRY POINT, NORTH CAROLINA
}

By Charles C. Daniel, III, Richard D. Miller, and Beth M. Wrege

\section{U.S. GEOLOGICAL SURVEY}

Water-Resources Investigations Report 95-4252

Prepared in cooperation with

DEPARTMENT OF THE NAVY, U.S. MARINE CORPS

Raleigh, North Carolina

1996 


\section{U.S. DEPARTMENT OF THE INTERIOR}

\section{BRUCE BABBITT, Secretary}

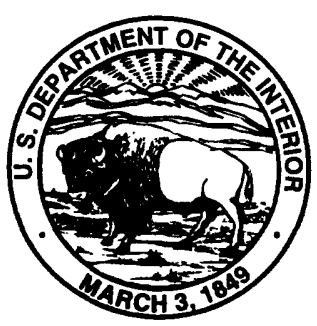

U.S. GEOLOGICAL SURVEY

Gordon P. Eaton, Director

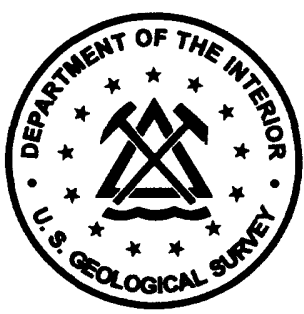

Any use of trade, product, or firm names in this report is for descriptive purposes only and do not constitute endorsement by the U.S. Government.

For additional information write to:

District Chief

U.S. Geological Survey 3916 Sunset Ridge Road

Raleigh, NC 27607
Copies of this report can

be purchased from:

U.S. Geological Survey

Earth Science Information Center

Open-File Reports Section

Box 25286, MS 517

Denver Federal Center

Denver, CO 80225 


\section{CONTENTS}

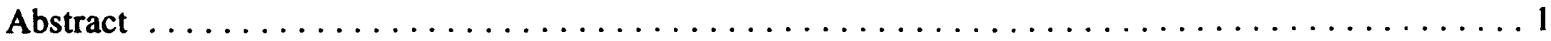

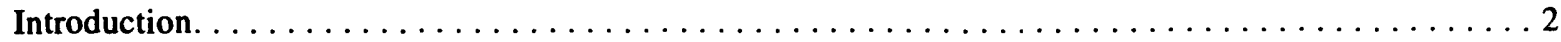

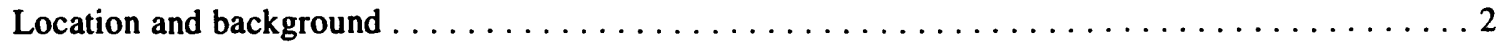

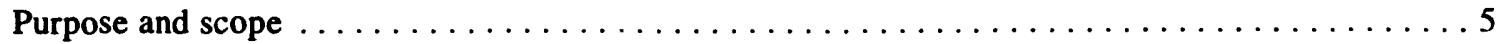

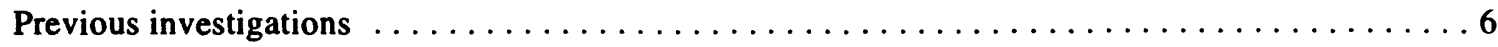

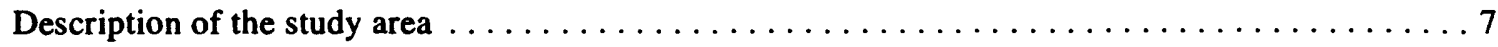

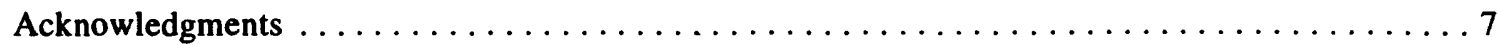

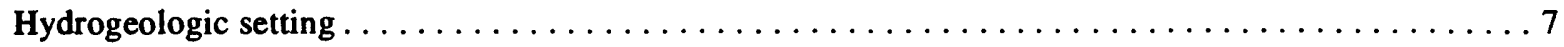

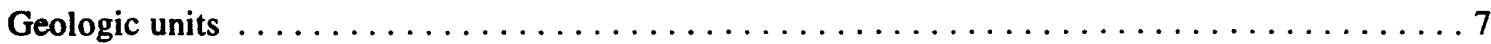

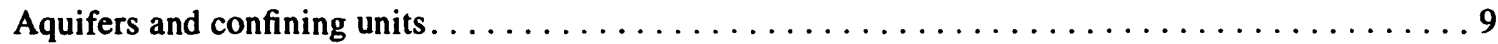

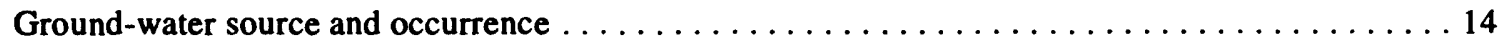

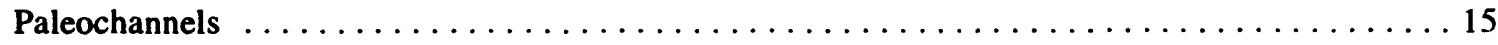

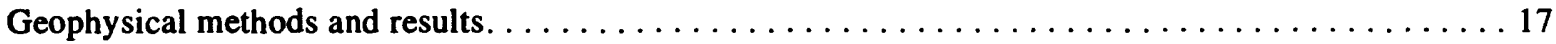

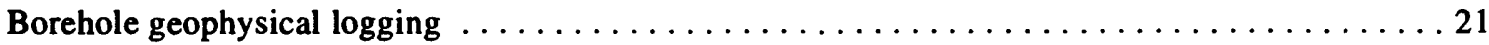

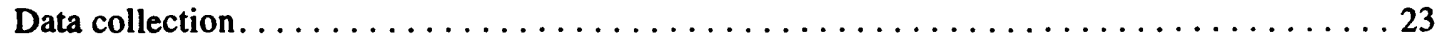

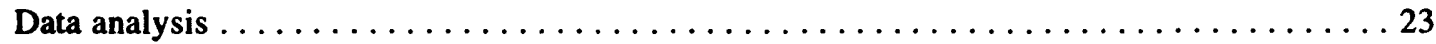

Results............................ 23

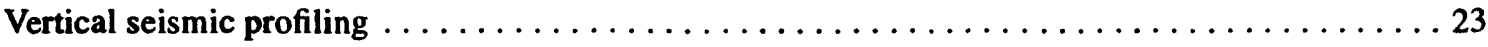

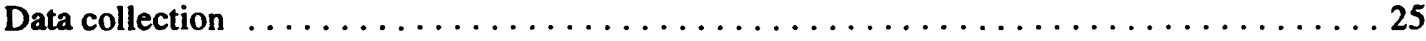

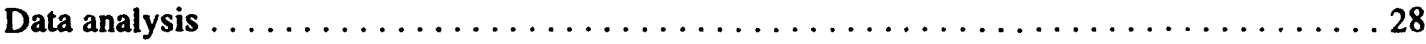

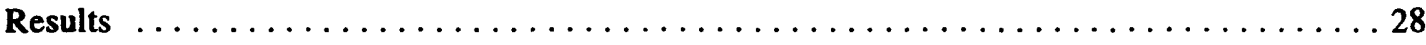

High-resolution land seismic-reflection profiling $\ldots \ldots \ldots \ldots \ldots \ldots \ldots \ldots \ldots \ldots \ldots \ldots \ldots$

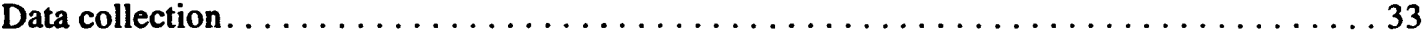

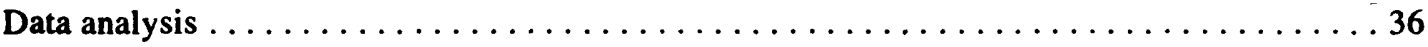

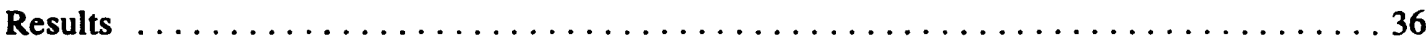

High-resolution marine seismic-reflection profiling $\ldots \ldots \ldots \ldots \ldots \ldots \ldots \ldots \ldots \ldots \ldots \ldots \ldots \ldots$

Data collection. . . . . . . . . . . . . . . . 40

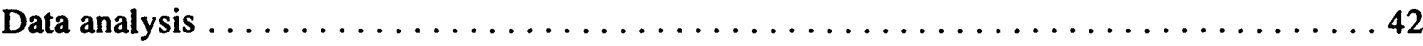

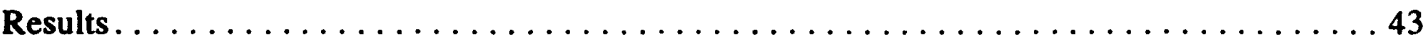

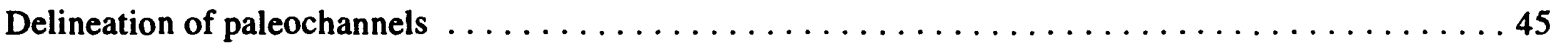

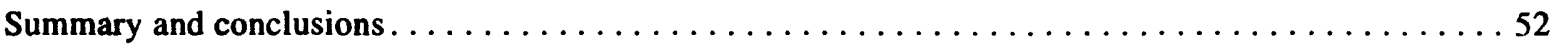

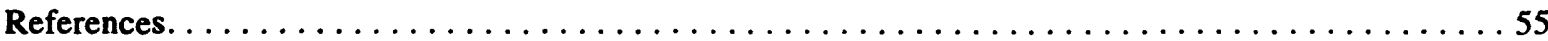




\section{FIGURES}

Figure 1. Map showing location of the North Carolina Coastal Plain and generalized geologic section of the Coastal Plain through the Cherry Point Marine Corps Air Station . . . . . . . 3

2. Map showing regional setting of the Air Station and location of hydrogeologic sections

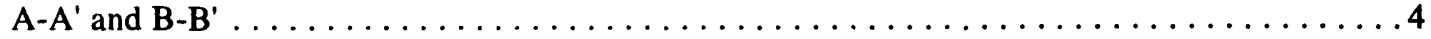

3. Generalized relation between geologic and hydrogeologic units beneath Cherry Point Marine Corps Air Station . . . . . . . . . . . . . . . . . . .

4. Hydrogeologic section A-A' at Cherry Point Marine Corps Air Station $\ldots \ldots \ldots \ldots \ldots \ldots \ldots$

5. Hydrogeologic section B-B' at Cherry Point Marine Corps Air Station $\ldots \ldots \ldots \ldots \ldots \ldots \ldots$

6. Block diagrams showing steps in the creation of a paleochannel in sedimentary deposits

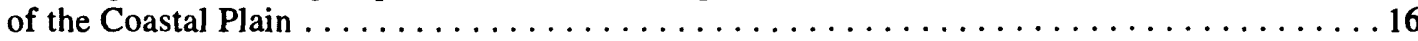

7. Map showing locations of known buried channels (paleochannels) in northern Onslow Bay in relation to the Neuse River and Cherry Point Marine Corps Air Station area . . . . . . . 18

8. Map showing locations of selected wells and seismic-reflection lines, Cherry Point Marine Corps Air Station . . . . . . . . . . . . . . . . . . . . . . . 19

9-12. Borehole geophysical logs for:

9. Stratigraphic test well 1--(A) natural gamma radiation,(B) acoustic velocity, and

(C) single-point resistance and spontaneous potential 58

10. Stratigraphic test well 2--(A) natural gamma radiation, (B) acoustic velocity, $(C)$ single-point resistance and spontaneous potential, (D) guard $\log$ (focused resistivity), (E) caliper, and (F) temperature.

11. Stratigraphic test well 3--(A) natural gamma radiation, (B) acoustic velocity, (C) single-point resistance and spontaneous potential, (D) guard log (focused resistivity), and (E) caliper . . . . . . . . . . . . . . . . . . . . . . . 69

12. Stratigraphic test well 4--(A) natural gamma radiation, and (B) single-point resistance and spontaneous potential. .

13. Schematic showing layout of source, seismograph, and receivers for conducting vertical seismic profiling in a borehole. Direct and reflected ray paths from three subsurface layer

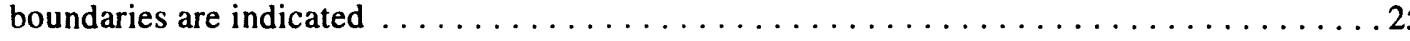

14. Comparison of a vertical seismic profile to a common-depth-point profile--(A) a vertical seismic profile (VSP) seismogram recorded with receivers spaced $5 \mathrm{ft}$ apart in the borehole of Strat-2, (B) the processed VSP that results from time shifting and stacking the raw seismogram record, and $(C)$ short $C D P$ seismic-reflection profile $A-3 \ldots \ldots \ldots 26$

15. Comparison of natural gamma-radiation logs and vertical seismic profile (VSP) stacks from

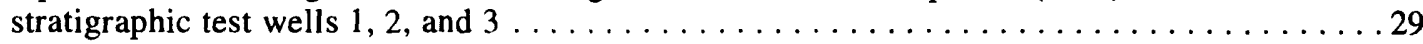

16. Reflection from one subsurface layer boundary. The angle of incidence of the downgoing ray

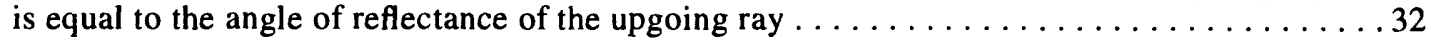




\section{FIGURES--Continued}

17. Reflection from three subsurface layer boundaries. The angle of incidence at the layer boundaries is different for each ray, but the reflection points are vertically equivalent. . . . . 32

18. The concept of common-depth point. Note that ray paths from two different shotpoints $\left(S_{1}\right.$ and $\left.S_{2}\right)$ reflect from a common point in the subsurface $\ldots \ldots \ldots \ldots \ldots \ldots$

19. Schematic showing a conceptual land seismic-reflection profile relating to real-world,

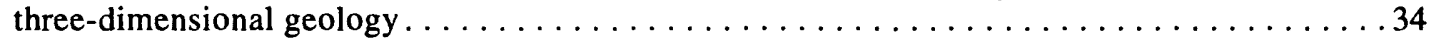

20. Generalized configuration of equipment and ray paths from acoustic source to hydrophones for single-channel marine seismic-reflection profiling $\ldots \ldots \ldots \ldots \ldots \ldots \ldots \ldots \ldots \ldots \ldots \ldots \ldots \ldots$

21. Map showing location of marine seismic-reflection profiles in the Neuse River north of

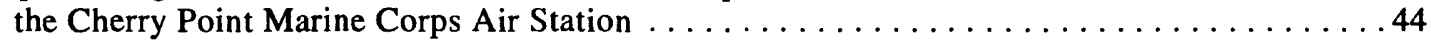

22. Composite marine seismic-reflection profile A-S along the south shore of the Neuse River north of Cherry Point Marine Corps Air Station. The composite profile has been divided into 18 sections at match points.

23. Map showing locations of suspected paleochannels beneath Cherry Point Marine Corps Air Station. . . . . . . . . . . . . . . . . . . . . . . . . . 46

24. Marine seismic-reflection profile of superimposed paleochannels beneath the Neuse River north of the Air Station--(A) seismic-reflection record, and (B) diagrammatic interpretation for profile.

25. Land seismic-reflection profile A-7--(A) seismic-reflection record, and (B) diagrammatic interpretation for profile.

26-28. Hydrogeologic sections along:

26. Roosevelt and Cunningham Boulevards between water-supply well 14 and stratigraphic

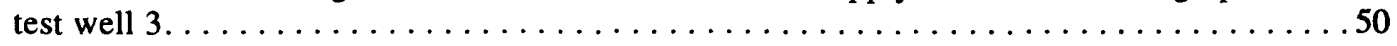

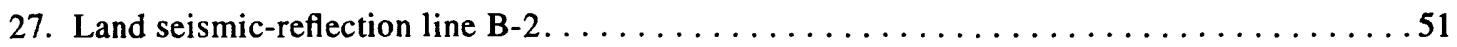

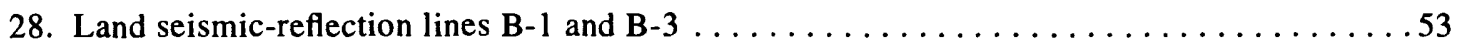

\section{TABLES}

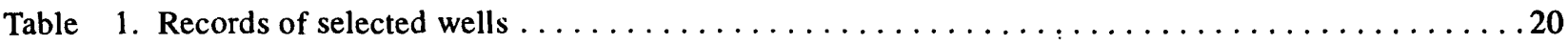

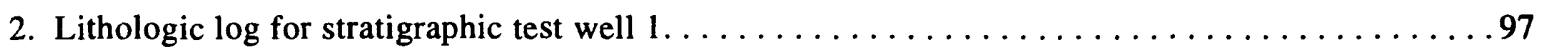

3. Lithologic $\log$ for stratigraphic test well $2 \ldots \ldots \ldots \ldots \ldots \ldots \ldots \ldots \ldots \ldots \ldots \ldots \ldots \ldots \ldots \ldots \ldots \ldots \ldots$

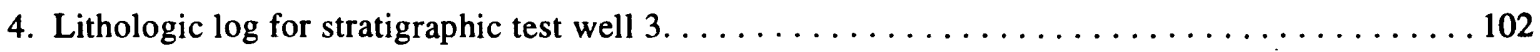

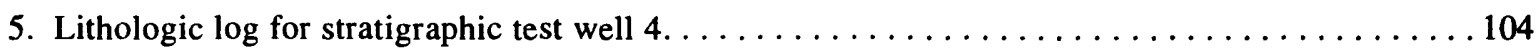

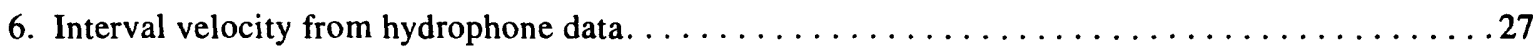

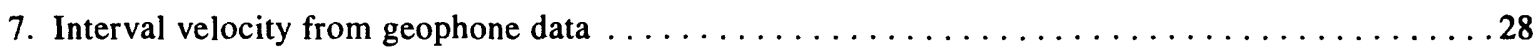

8. Two-way acoustic travel time at 5-foot intervals of depth between land surface and the

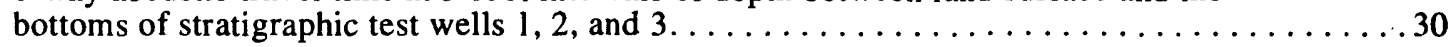

9. Reflection coefficients $(\mathrm{R})$ of typical geologic boundaries $\ldots \ldots \ldots \ldots \ldots \ldots \ldots \ldots \ldots \ldots$ 


\title{
APPLICATION OF GEOPHYSICAL METHODS TO THE DELINEATION OF PALEOCHANNELS AND MISSING CONFINING UNITS ABOVE THE CASTLE HAYNE AQUIFER AT U.S. MARINE CORPS AIR STATION, CHERRY POINT, NORTH CAROLINA
}

\author{
By Charles C. Daniel, III', Richard D. Miller², and Beth M. Wrege'
}

\section{Abstract}

The U.S. Marine Corps Air Station, Cherry Point, North Carolina, is located in southeastern Craven County in the Coastal Plain physiographic province. The Air Station is underlain by four freshwater-bearing aquifers--the surficial, Yorktown, and upper and lower Castle Hayne. These aquifers are composed primarily of sand and sandy limestone to a depth of about 500 feet below land surface. The sediments are saturated with saline water below this depth.

The upper and lower Castle Hayne aquifers serve as the principal supply of freshwater for the Air Station. The upper Castle Hayne aquifer is composed of sands and sandy shell beds of the Pungo River Formation and limestone of the River Bend Formation. The lower Castle Hayne aquifer is composed of limestones, sandy limestones, and sands of the Castle Hayne Limestone. The aquifers are separated by clay confining units except where these units are absent or discontinuous.

Ground-water contamination has been found in the southern part of the Air Station where pumping from supply wells has created a potential for downward movement of contaminated ground water from the surficial and Yorktown aquifers into the Castle Hayne aquifer. The potential for movement of water from the surficial aquifer downward to the water-supply aquifer is greatest in areas where clay confining units are missing. Missing confining units could indicate the presence of paleochannels. If paleochannels filled with permeable material exist beneath the Air Station, these features could act as conduits for ground-water flow or movement of contaminants between the surficial and Castle Hayne aquifers.

Continuous single-channel marine seismicreflection profiling was conducted to collect data for use in describing the structural and depositional setting of hydrogeologic units overlying the upper Castle Hayne aquifer. Soft, gassy, bottom sediment prevented collection of usable data in Slocum and Hancock Creeks on the west and east sides of the Air Station, respectively. Approximately 6.5 miles of seismic data were collected in the Neuse River north of the Air Station. A paleochannel structure nearly 1.2 miles wide and extending nearly 100 feet below sea level was found immediately north of the Air Station. This structure is thought to continue south beneath the Air Station.

Shallow high-resolution land seismicreflection techniques were used at the Air Station to delineate structures and correlate stratigraphy between the limestone of the River Bend Formation (about 180 feet below land surface) and the Yorktown confining unit (about 35 feet below land surface). Three different methods were used to acoustically image and correlate the subsurface geology to existing geologic, hydrogeologic, and geophysical data. The first method employed a series of thirteen 240-foot long 24-fold commondepth-point lines to optimize acquisition parameters and equipment selection and to acquire essential information about the acoustic properties of the upper 250 feet of sediment, both inside and outside the projected trace of a paleochannel.

\footnotetext{
'U.S. Geological Survey

${ }^{2}$ Kansas Geological Survey
} 
Guided by the 13 common-depth-point lines, four stratigraphic test wells were drilled to acquire lithologic and borehole geophysical data. Walkaway vertical seismic profiles were acquired in three of the wells. Finally, three 12 -fold common-depth-point seismic-reflection profiles with line lengths of 7,100 linear feet, 4,800 linear feet, and 4,760 linear feet were designed and run to target channel features inferred from drilling and the single-channel marine seismic-reflection survey. The land seismic-reflection techniques provided images of alternating sand and clay sequences with average thicknesses on the order of 20 to 30 feet. The land seismic data have a dominant frequency of about $200 \mathrm{Hertz}$, providing a minimum vertical bed resolution of about 6 feet.

An extremely complex series of erosional and depositional features can be interpreted on the common-depth-point seismic-reflection profiles. The northeastern margin of a large paleochannel that underlies the southern part of the Air Station was identified on two common-depth-point profiles. This feature strikes northwest to southeast and, based on data from test wells, cuts through the Yorktown and upper Castle Hayne aquifer confining units. Paleochannels and suspected stratigraphic breaks were identified at other locations, including beneath Access Road, Slocum Road, and the gravel road from Cunningham Boulevard to the south end of Delta taxiway.

Shallow seismic-reflection techniques were successful in delineating stratigraphic units and bedding geometries important to the definition of the hydrogeologic framework of unconsolidated sediments less than 180 feet deep at the Air Station. Paleochannels of Quaternary and Tertiary age were found at several locations. Marine seismic-reflection techniques were effective in delineating a large paleochannel complex consisting of at least two superimposed paleochannels. Land seismic-reflection techniques proved effective for the horizontal extrapolation of geologic features from well to well and identification of additional paleochannels.

\section{INTRODUCTION}

The water supply of the U.S. Marine Corps Air Station (MCAS) at Cherry Point, North Carolina, has been derived from the Castle Hayne aquifer since the Air Station opened in 1941. The quality of water in the Castle Hayne aquifer can be threatened with contamination by brackish water and(or) by wastes that have been disposed of or spilled at many sites on the Air Station (Lloyd and Daniel, 1988). Contamination from surface sources can occur with relative ease in areas where confining units above the Castle Hayne aquifer are thin or absent. Missing confining units could indicate the presence of paleochannels. If paleochannels filled with permeable material exist beneath the Air Station, these features could act as conduits for ground-water flow or movement of contaminants between the surficial and Castle Hayne aquifers.

\section{Location and Background}

The MCAS at Cherry Point is located in southeastern Craven County in the Coastal Plain physiographic province of North Carolina (fig. 1). The Air Station covers an area of about $19 \mathrm{mi}^{2}$ (square miles) just north of the town of Havelock and is bounded by the Neuse River estuary on the north, Hancock Creek on the east, North Carolina Highway 101 on the south, and an irregular north-south boundary located about $0.75 \mathrm{mi}$ (mile) west of Slocum Creek on the west (fig. 2).

In April 1986, the U.S. Geological Survey (USGS), in cooperation with the U.S. Marine Corps (USMC), began a series of ground-water resources investigations at the Air Station in response to increasing water-supply needs reported by the Air Station and the potential for contamination of the water-supply aquifer (Castle Hayne aquifer) by waste materials that were disposed of or spilled at numerous sites on the Air Station. Many of these sites are near wells that tap the Castle Hayne aquifer and supply potable water to the Air Station.

The Air Station relies solely on ground water for water supply and at present (1995) uses between 2.5 and $4.5 \mathrm{Mgal} / \mathrm{d}$ (million gallons per day). Since it opened in 1941, the Air Station's water supply has been derived from about 20 wells that range in depth from 195 to $330 \mathrm{ft}$ (feet). Each well is equipped to pump 

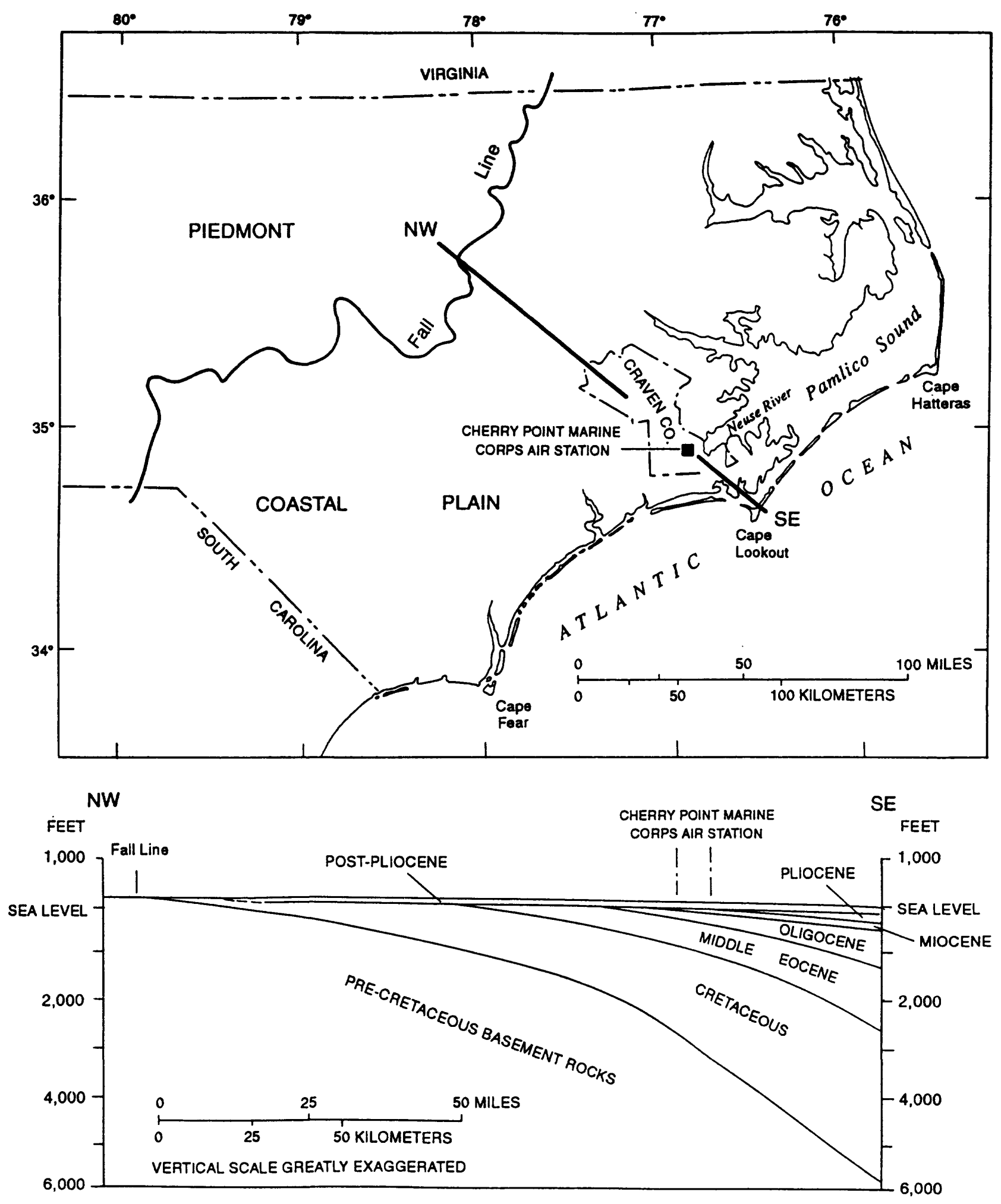

Figure 1. Location of the North Carolina Coastal Plain and generalized geologic section of the Coastal Plain through the Cherry Point Marine Corps Air Station. 


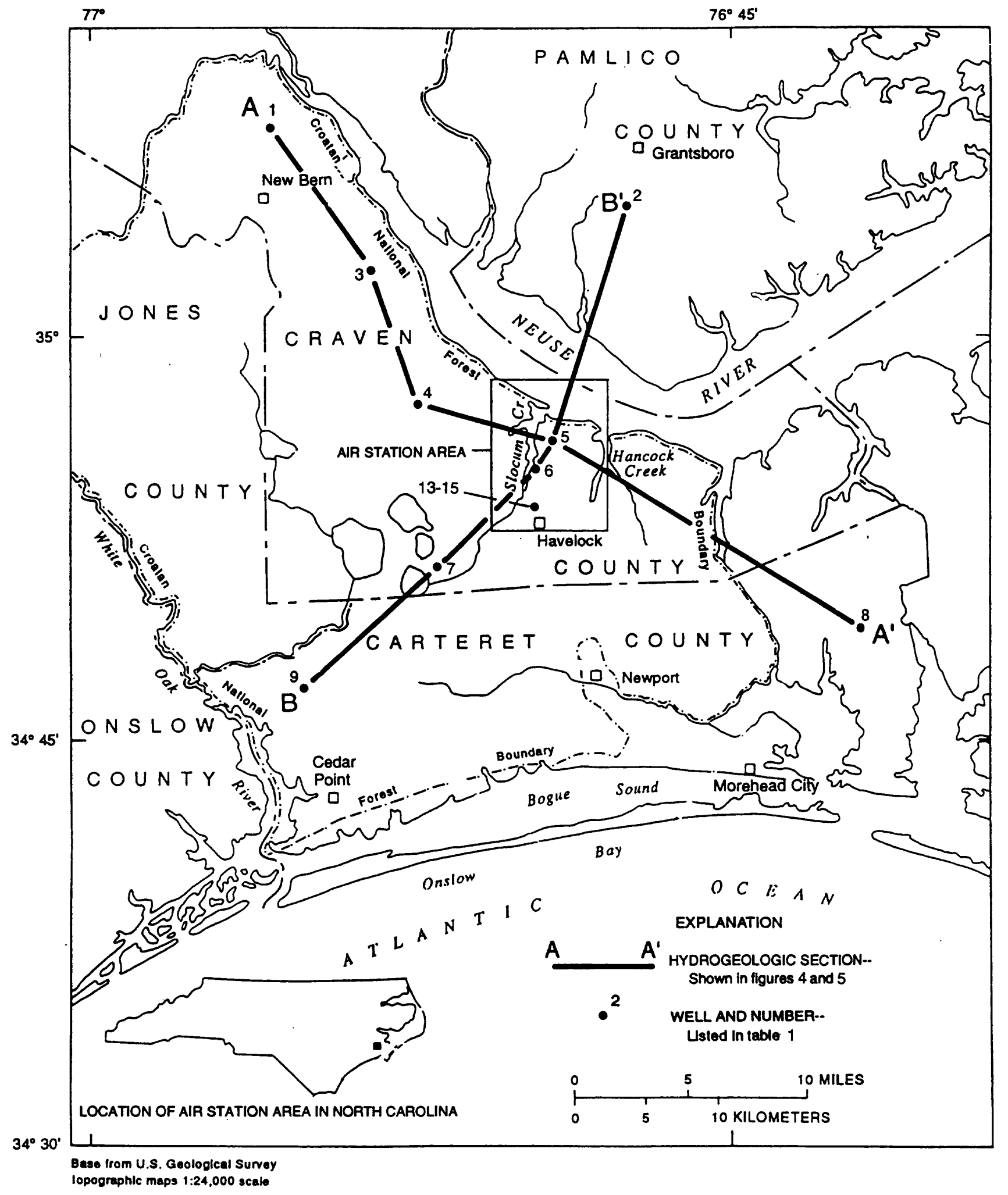

Figure 2. Regional setting of the Air Station and location of hydrogeologic sections $A-A^{\prime}$ and B-B' (adapted from Eimers and others, 1994). 
about $200 \mathrm{gal} / \mathrm{min}$ (gallons per minute), and the number of wells being used varies from less than half to all available as water needs fluctuate at the Air Station. In addition, a number of other wells supply water for nonpotable uses, including irrigation, fire control, and industrial cooling. The supply wells tap the Castle Hayne aquifer which is composed of an upper sand unit in contact with a thick carbonate sequence composed of porous limestone, sandy limestone, and lesser thicknesses of silty limestone, sand, and discontinuous clays. The aquifer can be divided into upper and lower units based on a silty, sandy clay layer within the carbonate sequence. Most wells tap the upper Castle Hayne aquifer, although several tap the lower Castle Hayne aquifer (Eimers and others, 1994).

Considerable amounts of residential and industrial wastes have been disposed of at numerous landfill sites on the Air Station. These wastes include hazardous wastes from aircraft refitting and manufacturing operations at the Air Station. Spills and leaks of waste and fuel also have occurred at several sites. The landfill sites, some of which were in use for over 40 years, lack natural or synthetic seepage barriers. Consequently, ground water is contaminated around many of the sites (NUS Corp., 1985, 1986, and 1987; Lloyd and Daniel, 1988; Murray and Keoughan, 1990) and hazardous chemicals have contaminated ground water at some Air Station water-supply wells (Lloyd and Daniel, 1988). By 1991, two wells had been shut down because of contamination. Since 1991, several new wells have been drilled to replace the abandoned wells and to meet increased demand.

Withdrawals from the water-supply wells have lowered the potentiometric surface of the Castle Hayne aquifer so that it is lower than the water table in the surficial aquifer and the potentiometric surface in the Yorktown aquifer over a larger area than existed in 1941 prior to withdrawals of large quantities of ground water. Thus, a potential now exists for the downward movement of contaminated water from the surficial and Yorktown aquifers to the deeper aquifers, including the Castle Hayne aquifer, the source of water for the supply wells.

Beneath much of the Air Station, the surficial, Yorktown, and Castle Hayne aquifers are separated by thick clay confining units. In some areas a third, discontinuous clay unit occurs within the surficial aquifer. The combined thickness of these clay units can be more than $70 \mathrm{ft}$, and they can effectively retard the movement of contaminants from the surficial aquifer downward into the Castle Hayne aquifer. However, beneath the southern part of the Air Station these units are discontinuous or missing. Erosion along a former river or stream channel (paleochannel) is a possible explanation for these missing units, and subsequent deposition of permeable sediment has filled the suspected paleochannel. Given a sufficient amount of pumpage from the Castle Hayne aquifer, ground water and any soluble contaminants could be induced to flow downward through the permeable sediment filling gaps in these confining units. The two wells that were abandoned because of contamination by organic compounds are located in this area.

Paleochannels cutting sediments the same age or younger than the Castle Hayne have been identified at several locations in eastern North Carolina (Riggs and O'Connor, 1974; Hine and Riggs, 1986; Cardinell and others, 1990). Therefore, a paleochannel beneath the Air Station is a distinct possibility. Because contamination of the Castle Hayne aquifer could occur rapidly in areas where confining units are absent, knowledge of these areas is critical for development of response plans to deal with spills or other incidents that could result in ground-water contamination. Therefore, the objectives of this study were to (1) use seismicreflection profiling techniques to delineate the location and geometry of the suspected paleochannel believed to underlie most of the industrial area located at the southern end of the Air Station, and (2) confirm results of the seismic-reflection profiling by drilling stratigraphic test wells along the seismic profile lines.

\section{Purpose and Scope}

The purpose of this report is to describe the results and present data for the paleochannel delineation study. The report describes, insofar as the present data base allows, (1) the hydrogeologic setting (the distribution of aquifers and confining units), (2) methods employed to evaluate the lateral extent and continuity of these units, and (3) areas where the aquifers and confining units have been dissected by erosion and downcutting of ancient stream channels (paleochannels).

The descriptions and interpretations that follow are primarily from a study of data obtained from land seismic-reflection profiling, high-resolution marine seismic-reflection profiling, available lithologic and 
borehole geophysical logs from deep water-supply wells and shallower water-quality monitoring wells, and lithologic logs, borehole-geophysical logs, and vertical seismic profiles from three of four new stratigraphic test wells drilled as part of this study. Field work for the study was conducted between August 1994 and March 1995. Emphasis was placed on the southern half of the Air Station where confining units are known to be thin or absent, although selected areas in the northern half of the Air Station were investigated because existing data for this large area are sparse or not currently available.

\section{Previous Investigations}

Several reports contain information about the hydrogeologic framework, the water levels, and the quality of ground water at the Air Station. The reports that were most helpful during the preparation of this report are briefly reviewed below.

Reports by LeGrand (1960), Floyd (1969), and Floyd and Long (1970) include information on the characteristics and quality of water from supply wells at the Air Station and describe the general geology and ground-water resources of the Craven County area. Kimrey $(1964,1965)$ and Miller (1982) describe the characteristics of the Miocene Pungo River Formation, which constitutes an important part of the hydrogeologic framework at the Air Station. Brown and others (1972) describe the geology and permeability distribution of the sedimentary rocks of the North Carolina coastal area and thus, those that occur beneath the Air Station as part of a regional study of the Atlantic Coastal Plain from North Carolina to New York.

The lithology and extent of various geologic formations that make up the Coastal Plain aquifers are discussed by Winner and Coble (1989) in their Regional Aquifer Systems Analysis (RASA) report of the hydrogeologic framework of the North Carolina Coastal Plain. They provide an extensive review of regional and local hydrogeologic investigations in the North Carolina Coastal Plain. Giese and others (1991) present results of the ground-water flow modeling performed in this RASA project.

Mixon and Pilkey (1976) present a generalized map showing the configuration of the base of Quaternary deposits in the study area. This map suggests the presence of a Neuse River paleochannel at the Air Station, a potentially critical feature of the hydrogeologic framework of the area. Hine and Riggs (1986) discuss the Cenozoic history of the region and present maps showing the distribution and thickness of Miocene deposits. Of critical importance are seismicreflection profiles collected in Onslow Bay between Cape Lookout and Cape Fear that illustrate numerous Quaternary stream channels that are cut into the inner continental shelf. Maps of buried channels in northern Onslow Bay indicate most Quaternary streams in the area between the Newport River and White Oak River flowed in a southerly or southeasterly direction. Some of the Quaternary deposits within the channel sequences are more than $60 \mathrm{ft}$ thick.

Lloyd and Daniel (1988) present a preliminary hydrogeologic setting, the distribution of hydraulic head within and between the aquifers, and the quality of water from 21 supply wells at the Air Station. Emphasis is on the western half of the Air Station where the greatest number of water-supply wells and historical waste-disposal and spill sites are located. They recognized that the confining units between the surficial, Yorktown, and Castle Hayne aquifers are thin and(or) discontinuous beneath the southern part of the Air Station and that contamination of supply wells in this area was probably related to downward movement of contaminants from the surficial aquifer through ' more permeable sediments above the Castle Hayne aquifer.

Murray and Daniel (1990) present hydrogeologic and water-quality data collected from four well clusters within the area of the wastewatertreatment plant and adjacent polishing lagoons. The data include lithologic descriptions, geophysical logs, water levels, laboratory tests for hydraulic conductivity, grain-size analysis, and results of waterquality analyses.

Murray and Keoughan (1990) present data collected from four monitoring-well clusters constructed near waste-disposal sites in the southwestern part of the Air Station. Hydrogeologic data collected at the four well-cluster sites included the distribution of hydraulic head within the Yorktown aquifer, and temporal and spatial differences in hydraulic head between the surficial, Yorktown, and Castle Hayne aquifers. Water-quality data collected from the surficial and Yorktown aquifers also are presented. The southernmost of the four well clusters described in this report extended the known area of thin or absent confining units reported by Lloyd and Daniel (1988). 
Eimers and others (1994) discuss the hydrogeologic framework beneath the Air Station and surrounding area, the hydraulic properties of the aquifers and confining units, the change of potentiometric surfaces in the aquifers since the Air Station opened in 1941, and the simulation of groundwater flow beneath the Air Station with a recently developed three-dimensional ground-water flow model. An analysis was made to evaluate the sensitivity of the model to the absence of the Yorktown and Pungo River confining units in a $1-\mathrm{mi}^{2}$ area in the southern part of the Air Station. There was no change in the water table, but there were minor increases in potentiometric heads in other units above the Castle Hayne. No head changes were evident throughout the 1- $\mathrm{mi}^{2}$ area in the upper Castle Hayne, lower Castle Hayne, or the Beaufort aquifers. The results of these simulations may change considerably if the area of missing confining units is found to be more extensive than previously thought.

The hydrogeologic framework at the Air Station, previously defined by Lloyd and Daniel (1988), was redefined by Keoughan (1988) and Murray and Keoughan (1990) based on more detailed lithologic analyses of cored material collected at four well-cluster sites and from other existing well data. The hydrogeologic framework used by Eimers and others (1994) for development of a quasi threedimensional finite-difference ground-water flow model of the Air Station was modified from the regional framework developed by Winner and Coble (1989) based upon the more detailed information provided by Lloyd and Daniel (1988), Keoughan (1988), and Murray and Keoughan (1990).

\section{Description of the Study Area}

The study area is the MCAS, Cherry Point, located north of the town of Havelock, North Carolina (fig. 2). The study area is in Craven County, in the Tidewater region of the Coastal Plain physiographic province (Fenneman, 1938), an area where large streams and tributaries are affected by oceanic tides (Stuckey, 1965). The topography is nearly flat on the interstream uplands and land-surface altitudes at the Air Station range from sea level to about $25 \mathrm{ft}$ above sea level. Shorelines are typically marked by bluffs that are dissected by steep-sided ravines.
The Air Station encompasses an area of approximately $19 \mathrm{mi}^{2}$. During the marine seismic surveys, the study area extended beyond the boundaries of the Air Station to include the Neuse River north of the Air Station.

\section{Acknowledgments}

The authors wish to thank the MCAS personnel for their cooperation and assistance during this study. The authors are particularly indebted to R. Doug Nelson, Renee Henderson, and George Radford from the Environmental Affairs Department who assisted with planning and logistical support during the data collection activities of this study. Special recognition is given to Will Wallen of Facilities Support Contracts Department who coordinated utility clearances and site access for drilling four stratigraphic test wells and land seismic profiling along nearly four miles of line.

\section{HYDROGEOLOGIC SETTING}

\section{Geologic Units}

The Air Station is located on an eastwardthickening wedge of Coastal Plain sediments (fig. 1) characterized by interbedded sands, clays, calcareous clays, shell beds, sandstone, and limestone deposited in marine or near-shore environments ranging in age from Cretaceous to Holocene (Brown and others, 1972; Winner and Coble, 1989). These sediments are part of the Coastal Plain rocks of North Carolina that, in aggregate, form a wedge-shaped mass that thickens from a feather-edge at the Fall Line (the western boundary of the Coastal Plain Province) to as much as $10,000 \mathrm{ft}$ at the coast (Brown and others, 1972, pl. 5; Winner and Coble, 1989). The Coastal Plain deposits are underlain by pre-Cretaceous igneous and metamorphic rocks (Daniels and Leo, 1985) similar to those exposed at land surface in the Piedmont Province west of the Fall Line.

The sedimentary deposits that underlie the Air Station are divided according to their age and lithology into a number of geologic units. These units are further divided according to their hydrogeologic characteristics into hydrogeologic units. The names and relations of these geologic and hydrogeologic units to one another is shown in figure 3 . 


\begin{tabular}{|c|c|c|c|}
\hline \multicolumn{3}{|c|}{ Geologic units } & \multirow{2}{*}{$\begin{array}{l}\text { Hydrogeologic units } \\
\text { Aquifer and confining unit } \\
\end{array}$} \\
\hline System & Series & Formation & \\
\hline \multirow{3}{*}{ Quaternary } & Holocene & Undifferentiated & \multirow{2}{*}{ Surficial aquifer } \\
\hline & \multirow{2}{*}{ Pleistocene } & Flanner Beach & \\
\hline & & James City & \multirow{2}{*}{$\begin{array}{c}\text { Yorktown confining unit } \\
\text { Yorktown aquifer }\end{array}$} \\
\hline \multirow{9}{*}{ Tertiary } & \multirow{2}{*}{ Pliocene } & \multirow{2}{*}{ Yorktown } & \\
\hline & & & \multirow[t]{2}{*}{ Pungo River confining unit } \\
\hline & \multirow[t]{2}{*}{ Miocene } & \multirow[t]{2}{*}{ Pungo River } & \\
\hline & & & \multirow{2}{*}{ Upper Castle Hayne aquifer } \\
\hline & \multirow{2}{*}{ Oligocene } & \multirow{2}{*}{ River Bend } & \\
\hline & & & \multirow{2}{*}{$\begin{array}{c}\text { Lower Castle Hayne confining unit } \\
\text { Lower Castle Hayne aquifer }\end{array}$} \\
\hline & \multirow[t]{2}{*}{ Eocene } & \multirow[t]{2}{*}{$\begin{array}{l}\text { Castle Hayne } \\
\text { Limestone }\end{array}$} & \\
\hline & & & \multirow[t]{2}{*}{ Beaufort confining unit } \\
\hline & Paleocene & Beaufort & \\
\hline \multirow{4}{*}{ Cretaceous } & \multirow{4}{*}{$\begin{array}{c}\text { Upper } \\
\text { Cretaceous }\end{array}$} & Peedee & $\begin{array}{c}\text { Peedee confining unit } \\
\text { Peedee aquifer }\end{array}$ \\
\hline & & $\begin{array}{l}\text { Black Creek and } \\
\text { Middendorf }\end{array}$ & $\begin{array}{l}\text { Black Creek confining unit } \\
\text { Black Creek aquifer }\end{array}$ \\
\hline & & & $\begin{array}{l}\text { Upper Cape Fear confining unit } \\
\text { Upper Cape Fear aquifer }\end{array}$ \\
\hline & & -аре геја & $\begin{array}{l}\text { Lower Cape Fear confining unit } \\
\text { Lower Cape Fear aquifer }\end{array}$ \\
\hline & & ceous crystalline & oasement rocks \\
\hline
\end{tabular}

Figure 3. Generalized relation between geologic and hydrogeologic units beneath Cherry Point Marine Air Station (modified from Murray and Keoughan, 1990; Eimers and others, 1994). 


\section{Aquifers and Confining Units}

The hydrogeologic units constitute a sequence of mappable hydrologic entities called aquifers and confining units. An aquifer may be composed of a formation, a group of formations, or part of a formation that contains a preponderance of saturated permeable material (sand and limestone in the Air Station area) that can yield significant quantities of water to wells. An aquifer may be composed of interconnected, saturated materials of different age.

In general, aquifers are adjacent to confining units, which are mostly composed of material that has low permeability (clay, or silty clay in the Air Station area). Confining units do not yield significant quantities of water to wells and they, too, may be composed of materials of different age.

The general regional distribution of aquifers and confining units in a northwest-southeast hydrogeologic section drawn through the Air Station from Craven County to Carteret County is shown in figure 4. Section A-A' is constructed approximately parallel to the dip of the Coastal Plain sediments. This section shows the general thickening of sediments to the southeast, as well as an increase in the number of individual beds in that direction. The dip of the hydrogeologic units beneath the Air Station increases with depth and ranges from about 5 to $35 \mathrm{ft} / \mathrm{mi}$ (feet per mile).

Hydrogeologic section B-B' (fig. 5) was constructed approximately at a right angle to section A$A^{\prime}$ to parallel the regional strike of the sediments; section $\mathrm{B}-\mathrm{B}^{\prime}$ intersects section $\mathrm{A}-\mathrm{A}^{\prime}$ at the Air Station (fig. 2). This section extends in a southwest-northeast direction from Carteret County to Pamlico County. The regional continuity of hydrogeologic units in the strike direction is shown on this section.

Four aquifers and three confining units separating them are saturated or partly saturated with freshwater (figs. 4 and 5). A test well drilled on the Air Station indicates that the freshwater/saline-water boundary beneath the Air Station is between 575 and $700 \mathrm{ft}$ below sea level, which locates the boundary within the Castle Hayne aquifer (Eimers and others, 1994, fig. 6). For purposes of this report, saline water is defined as water with chloride concentrations equal to or greater than $250 \mathrm{mg} / \mathrm{L}$ (milligrams per liter). (A chloride concentration in water of $250 \mathrm{mg} / \mathrm{L}$ is used by the U.S. Environmental Protection Agency (1984) to define the secondary limit of chloride concentration for drinking water.)
The framework presented by Eimers and others (1994) is currently the most comprehensive for the Air Station and vicinity and provides a hydrogeologic frame of reference for the discussion of paleochannels presented in this report. The subdivision of geologic and hydrogeologic units in figure 3 is a refinement of the subdivision presented by Eimers and others (1994) based on the work of Murray and Keoughan (1990) and findings from this study.

Boundaries of the model developed by Eimers and others (1994) are located about $15 \mathrm{mi}$ from the Air Station boundaries and enclose an area of about 686 $\mathrm{mi}^{2}$. Extension of the model boundaries beyond the Air Station was done for several reasons, including reducing potential errors in simulations that can often be traced to model boundary conditions. Another reason was to make the hydrogeologic framework of the Air Station model consistent with the previously developed regional framework. Of equal importance is the fact that there are several deep wells outside the Air Station boundaries that can be used for correlation of geologic and hydrogeologic units beneath the entire Air Station. However, studies by Lloyd and Daniel (1988) and Murray and Keoughan (1990) indicate some of the aquifers and confining units found beneath large areas of the Coastal Plain are missing or partially missing beneath the Air Station. The most extensive area so far identified lies beneath the southern part of the Air Station where the Yorktown and Pungo River confining units are missing. Another confining unit (the upper Castle Hayne confining unit) consists predominantly of sand, shells, and shell fragments beneath the southern and central part of the Air Station and probably offers little confinement to the underlying upper Castle Hayne aquifer. This change in hydrologic character probably can be attributed to a lateral facies change. The extent of this sandy facies of the upper Castle Hayne confining unit is not known. Current knowledge is limited to the central area (north to south) of the Air Station where a number of wells have been drilled into the underlying limestone and lithologic and geophysical logs of the wells have been obtained. Few wells have been drilled in the extreme western and eastern parts of the Air Station, and even fewer wells have been drilled outside the Air Station boundaries.

A detailed description of the aquifers and confining units, particularly thcse occurring in the upper $500 \mathrm{ft}$ beneath the Air Station, is possible because of the data available from numerous wells drilled there in the past. Data from these wells were 


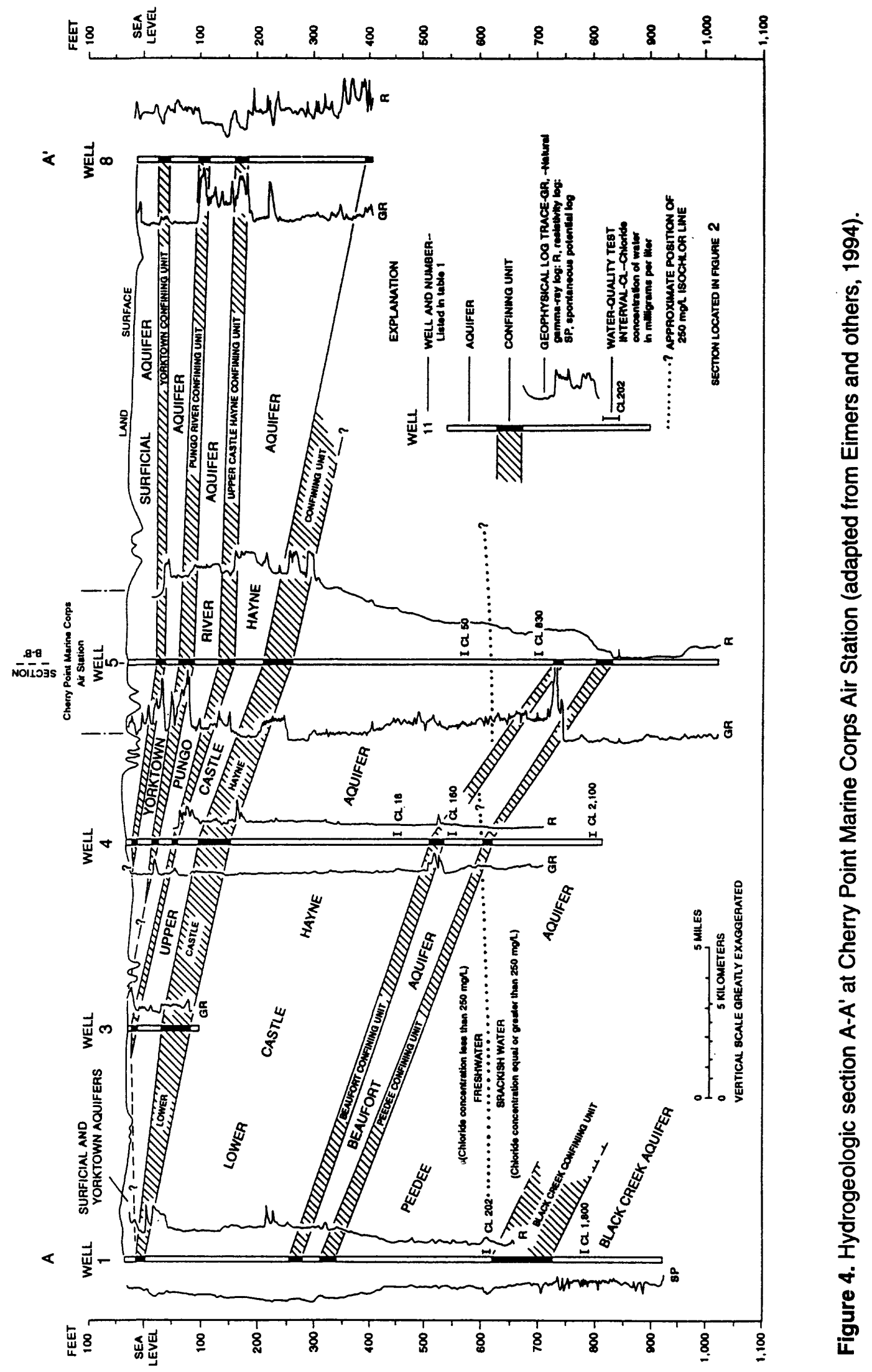




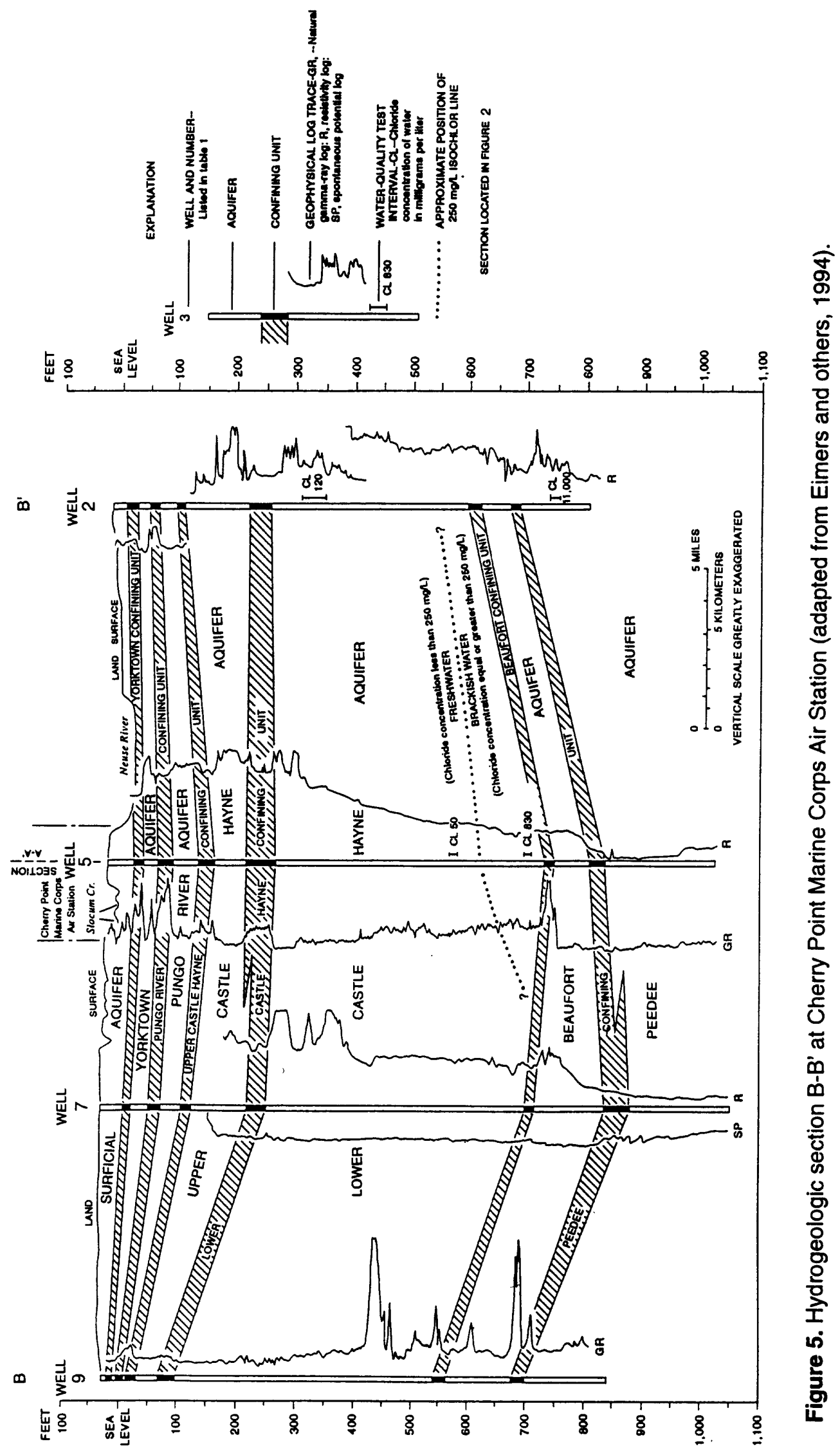


correlated during previous studies to construct a hydrogeologic framework of aquifers, confining units, and attendant information about potentiometric surfaces and the distribution of freshwater and brackish water within the aquifers and confining units. Although the Pungo River aquifer and upper Castle Hayne confining unit apparently function hydrologically as part of the upper Castle Hayne aquifer beneath much of the Air Station, the characteristics of this aquifer and confining unit are described separately from those of the upper Castle Hayne aquifer to maintain consistency with the regional framework. A description of this framework follows.

The surficial aquifer is the uppermost aquifer of the study area and is exposed at land surface and in streambeds throughout the Air Station (figs. 4 and 5). This aquifer consists of unconsolidated and interfingering beds of fine sand, silt, clay, shell and peat beds, and scattered deposits of coarser-grained material as part of relic beach ridges and alluvium. The surficial aquifer is estimated to contain 70- to 80percent sand. Discontinuous beds of clay, sandy clay, and silt form local confining units within the surficial aquifer (Lloyd and Daniel, 1988, plate 1; Eimers and others, 1994, figs. 8 and 9). These beds range from less than 5 to more than $15 \mathrm{ft}$ thick in the southern part of the Air Station. The sediments are of shallow marine and near-marine origin of Pleistocene to Holocene age. Discounting the relic beach ridges and recent alluvium, the sediments of the surficial aquifer are considered by Murray and Keoughan (1990) to be the Flanner Beach Formation of middle Pleistocene age as defined by Mixon and Pilkey (1976) (fig. 3).

The observed thickness of the surficial aquifer ranges from 31 to $68 \mathrm{ft}$. The aquifer is thinnest and could be absent where it is cut into by the Neuse River and its tributaries (fig. 5). The greatest thickness of the surficial aquifer occurs in the southern part of the Air Station where the unit is more than $50 \mathrm{ft}$ thick. In at least one area in the southern part of the Air Station, the surficial aquifer is in direct contact with the Yorktown aquifer; the locally merged sands of the surficial aquifer and the upper unit of the Yorktown aquifer could account for the thickness exceeding $60 \mathrm{ft}$. The surficial aquifer immediately overlies the Yorktown confining unit, except in those areas where the confining unit is missing.

The Yorktown confining unit is composed of clay and sandy clay with locally discontinuous, thin beds of fine sand, silty sand, or shells. The Yorktown confining unit is not exposed at land surface on the Air Station, but the Neuse River channel may be incised into it in this vicinity (Winner and Coble, 1989, plate 18). The confining unit thickens to the southeast across the Air Station; where it is present, the observed thickness of the confining unit ranges from 5 to $34 \mathrm{ft}$ thick (Eimers and others, 1994, fig. 12). The Yorktown confining unit is missing in at least one area beneath the southern part of the Air Station. Eimers and others (1994, p. 17) considered the Yorktown confining unit to be the uppermost sediments of the Yorktown Formation of Pliocene age (Ward and Blackwelder, 1980). However, findings from this study suggest that the Yorktown confining unit primarily rests on an erosional surface (unconformity) and is distinct from the underlying Yorktown aquifer. These findings are consistent with interpretations by Keoughan (1988) and Murray and Keoughan (1990) who assigned the Yorktown confining unit to the James City Formation of early Pleistocene age (Dubar and Solliday, 1963). For purposes of this report, the Yorktown confining unit is considered Pleistocene in age (fig. 3).

The Yorktown aquifer underlies the Yorktown confining unit throughout much of the study area. The Yorktown aquifer consists of unconsolidated fine sand, silty and clayey sand, and clay; shell beds also occur in the unit and indicate a marine depositional environment. Winner and Coble (1989, plate 19) estimated the Yorktown aquifer to contain 70- to 80 -percent sand in the vicinity of the Air Station. However, based on lithologic and textural properties from drillers' logs and cores from wells at the Air Station, clay and silt content can be highly variable within the Yorktown aquifer.

The altitude at the top of the Yorktown aquifer ranges from less than 35 to more than 50 feet below sea level (Eimers and others, 1994, fig. 11) and dips southeast at about $4.5 \mathrm{ft} / \mathrm{mi}$. The average altitude is 43 $\mathrm{ft}$ below sea level, based on observed values at the Air Station (Eimers and others, 1994, table 2). The greatest thickness of the Yorktown aquifer occurs in the southern and eastern parts of the Air Station where the unit is more than $50 \mathrm{ft}$ thick. The average thickness is about $35 \mathrm{ft}$ at the Air Station. The Yorktown aquifer immediately overlies the Pungo River confining unit except in the southern part of the Air Station where this confining unit is missing and the Yorktown aquifer is in direct contact with the Pungo River aquifer. 
The Pungo River confining unit overlies the Pungo River aquifer and is composed of contiguous sandy clays of the lowermost Yorktown Formation and the upper clay (including clay containing some phosphatic sand) and sandy silt beds of the Pungo River Formation of middle Miocene age (Kimrey, $1964 ; 1965)$. The confining unit is thickest beneath the runway area of the Air Station; the observed confiningunit thickness ranges from 7 to $33 \mathrm{ft}$ (Eimers and others, 1994, fig. 14, table 2).

The Pungo River confining unit is inferred to be missing in at least one place at the south end of the Air Station, possibly because of erosion, nondeposition of clay, or the presence of a paleochannel. There may be other places at the Air Station where the Pungo River confining unit is missing, and test drilling and geophysical exploration will be required to determine these locations. Except where this confining unit is missing, the Pungo River confining unit immediately overlies the Pungo River aquifer.

The Pungo River aquifer consists of fine- to medium-grained sand with some local beds of silt, clay, and phosphatic sand. Eimers and others (1994) estimated that the Pungo River aquifer contains about 70-percent sand in the southern part of the Air Station, based on analyses of geophysical logs. Winner and Coble (1989) estimated that the Pungo River aquifer contains 80- to 90-percent sand at the Air Station. Thin beds (less than $1 \mathrm{ft}$ thick) of chert and chert-cemented sand have been encountered in several wells. These beds are sufficiently indurated that a roller cone bit is required to drill through them. A few beds of coarse sand also occur in the unit. Shells and shell fragments are scarce.

The altitude at the top of the Pungo River aquifer ranges from less than 85 to more than $128 \mathrm{ft}$ below sea level; the unit dips east-southeast at about $10 \mathrm{ft} / \mathrm{mi}$. The average altitude at the top of the aquifer is about 97 ft below sea level (Eimers and others, 1994, fig. 13 and table 2). At the Air Station, the thickest part of the aquifer occurs in the southern part of the Air Station where the unit is $70 \mathrm{ft}$ thick. The Pungo River aquifer immediately overlies the upper Castle Hayne confining unit.

Throughout much of the extent of the Castle Hayne aquifer in eastern North Carolina, the aquifer is considered a single hydrogeologic unit. However, because of the presence of a zone of lower permeability in the Castle Hayne aquifer in the vicinity of the Air Station, Eimers and others (1994) divided the aquifer into upper and lower units to better simulate the flow of ground water through the system.

Regionally, the upper Castle Hayne confining unit consists of interbedded clays, sandy clays, silts, sands, and phosphatic and nonphosphatic limestones that occur in the basal unit of the Pungo River Formation. Locally, however, beneath the Air Station this confining unit consists of sand, silty sand, and abundant shells and shell fragments. Thin beds of sand also are present. In the Air Station area, the observed thickness of the confining unit ranges from 12 to $45 \mathrm{ft}$, and is thickest in the central and northeastern part of the Air Station (Eimers and others, 1994, fig. 16; table 2). Beneath the Air Station, this unit offers little confinement to the underlying River Bend Formation (a voidic limestone), and functions hydrologically as part of the upper Castle Hayne aquifer.

The upper Castle Hayne aquifer is present everywhere beneath the Air Station. Regionally, the upper Castle Hayne aquifer is composed primarily of the porous limestones, sandy limestones, and discontinuous beds of medium to fine sand that constitute the River Bend Formation. Thin, discontinuous beds of clay also can be present. The altitude of the top of the River Bend Formation ranges from less than 155 to nearly $200 \mathrm{ft}$ below sea level, and the formation dips southeast under the Air Station at about $15 \mathrm{ft} / \mathrm{mi}$. On the Air Station, this formation ranges from about $30 \mathrm{ft}$ thick on the west to about $85 \mathrm{ft}$ thick on the east side (Eimers and others, 1994, fig. 15; table 2).

The lower Castle Hayne confining unit overlies the lower Castle Hayne aquifer and is composed of clay, sandy clay, and sand. The observed thickness of the confining unit ranges from about 15 to $50 \mathrm{ft}$; the confining unit is slightly thicker in the northern part of the Air Station (Eimers and others, 1994, fig. 18; table 2).

The lower Castle Hayne aquifer is composed primarily of the limestone, sandy limestone, calcareous sand, and clay beds of the Castle Hayne Limestone of Eocene age. Thin, discontinuous layers of consolidated limestone also are present. The aquifer grades to progressively finer-grained sediments with depth; fine sand mixed with silt and clay dominate the lower two-thirds of the unit (figs. 4 and 5). The altitude of the top of the lower Castle Hayne aquifer ranges from less than $220 \mathrm{ft}$ to more than $320 \mathrm{ft}$ below sea level and dips southeast under the Air Station at about $16 \mathrm{ft} / \mathrm{mi}$ (Eimers and others, 1994, fig. 17 and table 2). 
The thickness of the lower Castle Hayne aquifer ranges from about 465 to $500 \mathrm{ft}$, based on data from four wells that penetrate the unit at the Air Station (Eimers and others, 1994, table 2). Brackish water occurs in the lower Castle Hayne aquifer at a depth of about $625 \mathrm{ft}$ below sea level at the Air Station.

Other aquifers and confining units underlie the Castle Hayne aquifer at the Air Station (fig. 3); however, these aquifers contain brackish water and are not used for water supplies. The Castle Hayne aquifer is the principal water supply for many domestic, municipal, and industrial users in eastern North Carolina, including the Air Station and nearby town of Havelock (Lloyd and Daniel, 1988). The hydrogeologic units of interest in this study are the aquifers and particularly the confining units that collectively overlie the Castle Hayne aquifer. The absence of any of these confining units increases the susceptibility of the Castle Hayne aquifer to contamination from the land surface.

The hydrogeologic unit previously described as the Castle Hayne aquifer by Lloyd and Daniel (1988) included the middle and lower units of the Pungo River Formation of Miocene age, the River Bend Formation of Oligocene age, and the Castle Hayne Limestone of middle Eocene age (Ward and others, 1978).

Throughout much of the North Carolina Coastal Plain, a confining unit lies at the base of the Pungo River Formation and above the River Bend Formation and Castle Hayne Limestone (Winner and Coble, 1989). However, lithologic and geophysical logs indicate that this confining unit offers little confinement in the vicinity of Cherry Point. Therefore, the Castle Hayne aquifer beneath the Air Station includes the lower beds of the Pungo River Formation and the underlying River Bend Formation and Castle Hayne Limestone. In effect, the Pungo River confining unit functions as the upper Castle Hayne confining unit in the vicinity of the Air Station. Beneath the Air Station, the Castle Hayne aquifer extends from a depth of approximately 120 to at least $750 \mathrm{ft}$ below land surface.

\section{Ground-Water Source and Occurrence}

All of the sedimentary deposits from the top of the basement rocks to about $15 \mathrm{ft}$ below land surface (the approximate maximum depth to the water table at the Air Station) are saturated with ground water (Lloyd and Daniel, 1988). The water occurs in and moves through the void spaces within the sedimentary deposits. At the Air Station, approximately $3,000 \mathrm{ft}$ of sedimentary deposits overlie crystalline basement rocks (fig. 1).

The ground water that occurs between land surface and about $600 \mathrm{ft}$ below land surface is freshwater containing chloride concentrations less than $250 \mathrm{mg} / \mathrm{L}$. The chloride concentrations increase with increasing depth and may be as much as $19,000 \mathrm{mg} / \mathrm{L}$ (seawater concentration) near the bottom of the sedimentary deposits beneath the Air Station. The source of the freshwater is precipitation; seawater occurs naturally in marine sediments as a consequence of their deposition.

The ground water in the zone of saturation occurs under confined and unconfined conditions. It occurs under unconfined conditions only in shallow aquifers, such as the surficial aquifer where there are no confining units between the water table and land surface. Under these conditions, the ground water is at atmospheric pressure at the water table; the water table is free to rise and fall and its altitude can be determined from water levels measured in shallow wells that tap the aquifer at or just below the water table. Ground water occurs under confined conditions in deeper aquifers that are confined above and below by layers of low-permeability material like clay. Under these conditions, the water level in a tightly cased, nonpumping well will stand above the top of the aquifer; this water level defines a point on the potentiometric surface of a confined, or artesian, aquifer. The movement of water through the groundwater system, such as that at the Air Station, is described by Heath (1983, p. 4) as follows:

\footnotetext{
"Water enters the ground-water system in recharge areas and moves through them, as dictated by the hydraulic gradients and hydraulic conductivities, to discharge areas... In the humid part of the country, recharge occurs in all interstream areas--that is, in all areas except along streams and their adjoining flood plains. The streams and flood plains are, under most conditions, discharge areas."
}

In the North Carolina Coastal Plain, recharge to unconfined aquifers is derived from infiltration of rainfall in interstream areas. Estimates of recharge to unconfined parts of the Coastal Plain aquifers range between 5 and 21 in (inches) yearly (Heath, 1980). Heath (1975) estimated that recharge to confined 
aquifers in the Albemarle-Pamlico sound area is derived from downward leakage through overlying units and is about $0.5 \mathrm{in} / \mathrm{yr}$ (inch per year). Winner and Simmons (1977) estimated recharge to the Castle Hayne aquifer in Beaufort, Craven, and Pitt Counties to be about $0.8 \mathrm{in} / \mathrm{yr}$.

Most ground water is naturally discharged from unconfined Coastal Plain aquifers by seepage into streams, swamps, and lakes. Ground water also is discharged by evapotranspiration from soil zones. Discharge from confined aquifers is by upward leakage through overlying units to stream valleys, estuaries, and the ocean. Under nonstressed (nonpumping) conditions, the long-term average discharge from the aquifers equals the long-term average recharge. The bulk of ground-water discharge, other than that lost to riparian evapotranspiration, provides the base flow of perennial streams.

According to Giese and others (1991), the regional water budget can be summarized as follows. About $12 \mathrm{in} / \mathrm{yr}$ of the mean annual precipitation (about $50 \mathrm{in} / \mathrm{yr}$ ) infiltrates to the water table; about $5 \mathrm{in} / \mathrm{yr}$ travels by overland flow to surface-water bodies, and about $33 \mathrm{in} / \mathrm{yr}$ is returned to the atmosphere by evapotranspiration. Most of the ground water (about $11 \mathrm{in} / \mathrm{yr}$ ) in the surficial aquifer discharges to surfacewater bodies. Only about 0.5 to $1.0 \mathrm{in} / \mathrm{yr}$ of total precipitation travels below the first confining unit.

\section{Paleochannels}

A paleochannel is the remnant of a stream or river channel cut into older rock and filled by sediments of younger overlying rock--in short, a buried river channel (Gary and others, 1974). Paleochannels have been identified beneath the Coastal Plain of Eastern North Carolina in a number of studies (Riggs and O'Connor, 1974; Mixon and Pilkey, 1976; Daniel, 1981; Hine and Riggs, 1986). A paleochannel beneath the southern part of the Air Station has been proposed as a possible explanation for missing confining units identified from lithologic and geophysical logs of supply wells and test wells drilled in that area (Murray and Keoughan, 1990; Eimers and others, 1994).

The work by Hine and Riggs (1986) provides considerable insight into understanding the morphology, stratigraphic relations, and regional drainage patterns that may be associated with paleochannels at the Air Station. Using seismicreflection techniques coupled with lithologic and paleontological analyses of sediment cores taken by vibracore, Hine and Riggs (1986) mapped the Tertiary and Quaternary stratigraphy of Onslow Bay. In northern Onslow Bay, late Tertiary (Oligocene, Miocene, Pliocene) stratigraphic units outcrop on the ocean floor where they have been exposed by submarine erosion. In some areas these units are only slightly buried by blanket sands. Seismic profiles indicate that these units dip generally to the east. Data from wells onshore also indicate that these units extend along strike in the subsurface north of Onslow Bay. Fifteen miles north of Onslow Bay, these units are found beneath the Air Station. Depositional and erosional sequences identified beneath Onslow Bay are probably very similar to conditions in the vicinity of the Air Station.

The seismic and paleontological data presented by Hine and Riggs (1986) provide evidence of a complex sequence of Cenozoic erosional and depositional events attributed to multiple Cenozoic sea-level fluctuations. As many as $\mathbf{1 8}$ depositional sequences have been identified within the composite Miocene section of Onslow Bay (Hine and Riggs, 1986). Other units exhibit similar complexity. Because most of the sea-level fluctuations were highamplitude events (greater than $300 \mathrm{ft}$ ), the shoreline migrated laterally across large areas of the ancestral Coastal Plain and produced major changes in physical processes and depositional environments.

Consequently, the Cenozoic stratigraphy of the area is not only characterized by numerous erosional surfaces, but also highly-variable lithologies with complex relations in lateral and vertical facies.

The block diagrams in figure 6 illustrate the process of paleochannel formation in a coastal environment such as eastern North Carolina. During periods of little or no sea-level change, streams and rivers developed mature drainage patterns and broad flood plains. During periods of shoreline advancement, streams and rivers migrated out onto the newly exposed Coastal Plain surface. As sea level declined, incision of river channels occurred inland of the shoreline, and prograde deposition of the sediment removed by channel incision and subaerial erosion occurred at the river mouths. During periods of sea level rise and shoreline retreat, surficial deposits were reworked or eroded, and former river channels were infilled by sediment. Some rivers may have resembled modern estuaries where sediment is accumulating and 



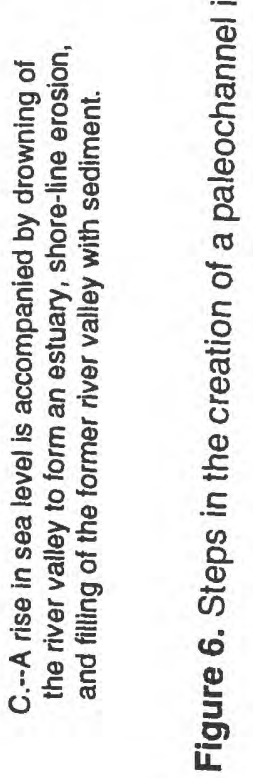


sea-level rise and landward advance of the shoreline continually modifies the morphology of these drowned river valleys. When sea level recedes, the former sea floor is exposed revealing a surface of low relief, and the process of erosion and development of drainage systems begins again.

Numerous buried channels of Quaternary age have been identified in northern Onslow Bay (Hine and Snyder, 1985). Many of these are incised into the underlying Tertiary units. In northern Onslow Bay, the thickest Quaternary sediments are contained within the buried channel sequences (Hine and Riggs, 1986).

Many of these channels are oriented in a north to south or north-northwest to south-southeast direction and occur at progressively greater depths south of the current shoreline (fig. 7). Along the shoreface, some of the Quaternary channels are still overlain by flat-lying Quaternary sediments that have not been removed by erosion along the retreating shoreface (Hine and Riggs, 1986, fig. 49). North of Onslow Bay these Quaternary sediments extend to the vicinity of the Air Station and beyond. They are exposed in the bluffs along the Neuse River where they appear to be laterally extensive and relatively flat lying, although there is some evidence of a slight east or southeast dip.

Based on information provided by Hine and Snyder (1985) and Hine and Riggs (1986), it is likely that any Quaternary paleochannels found in the vicinity of Cherry Point are associated with the paleochannels found beneath Onslow Bay and represent part of a regional drainage system flowing generally from north to south across this area of the Quaternary Coastal Plain. It is also likely that any Quaternary paleochannels at the Air Station will be infilled and overlain by younger Quaternary sediments.

The presence of numerous erosional, or truncation, surfaces within the Miocene Pungo River Formation, as well as in other Tertiary units, indicates that conditions also would have been favorable for channel formation at times during the Tertiary when the region was subaerially exposed. Cut-and-fill structures probably associated with Tertiary paleochannels have been identified beneath Onslow Bay (Hine and Riggs, 1986). Thus, it is plausible that paleochannels of various ages could exist within the Quaternary and Tertiary units beneath the Air Station.

The role of paleochannels in the hydrogeology of the Air Station will depend on whether (1) channels are present, (2) channels have eroded through confining units above the Castle Hayne aquifer, and (3) fill in the paleochannels contains clay or other sediment layers that can function as confining units to replace those that have been breached. If the fill is more permeable than the confining units that have been breached, then movement of water between the surficial and Castle Hayne aquifers will be facilitated. The use of a variety of techniques, including land and marine seismic-reflection surveys, test drilling, collection of lithologic samples, and borehole geophysical logging, has helped identify geologic structures and lithologies beneath the Air Station.

\section{GEOPHYSICAL METHODS AND RESULTS}

During the course of this study, a variety of geophysical methods were employed in an effort to identify geologic structures, including paleochannels, beneath the Air Station. Methods included borehole geophysical logging of stratigraphic test wells, highresolution land and marine seismic-reflection profiling, and collection of vertical seismic profiles (VSP's) in stratigraphic test wells (fig. 8; table 1). Borehole geophysical logs can be used to identify different lithologies penetrated by wells and to facilitate construction of geologic sections through correlation of subsurface lithologic units. The VSP data are the basis for computing estimates of depths to reflectors from two-way travel times obtained during the land and marine seismic-reflection surveys. Land seismicreflection profiling can identify complex structures that are not likely to be identified from stratigraphic test wells. Detailed descriptions of data-collection methods, data, and interpretations for the VSP's and land seismic-reflection profiling are contained in a report by Miller and others (1995). Results of the work by Miller and others (1995) are briefly summarized in later sections of this report, along with hydrogeologic sections and interpretations based, in part, on this work. Because the Air Station is bordered on three sides by the Neuse River, Slocum Creek, and Hancock Creek, marine seismic-reflection profiling offered a rapid and relatively cost-effective method of producing continuous profiles characteristic of geologic units underlying a substantial part of the Air Station. The methods employed and results obtained during this study are described in more detail in the following sections. 


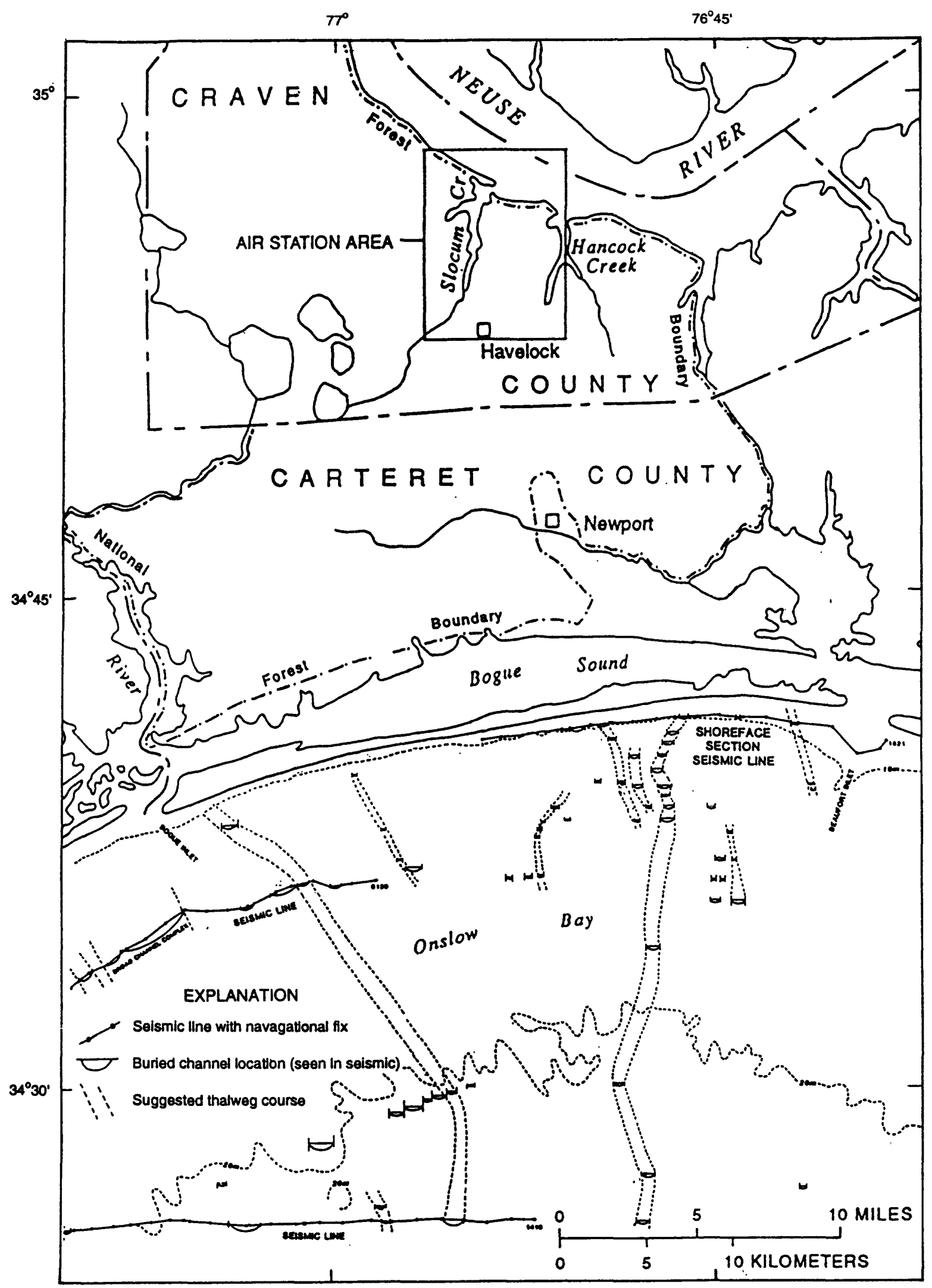

Figure 7. Locations of known buried channels (paleochannels) in northern Onslow Bay in relation to the Neuse River and Cherry Point Marine Corps Air Station area (modified from figure 2 of Hine and Snyder, 1985). 


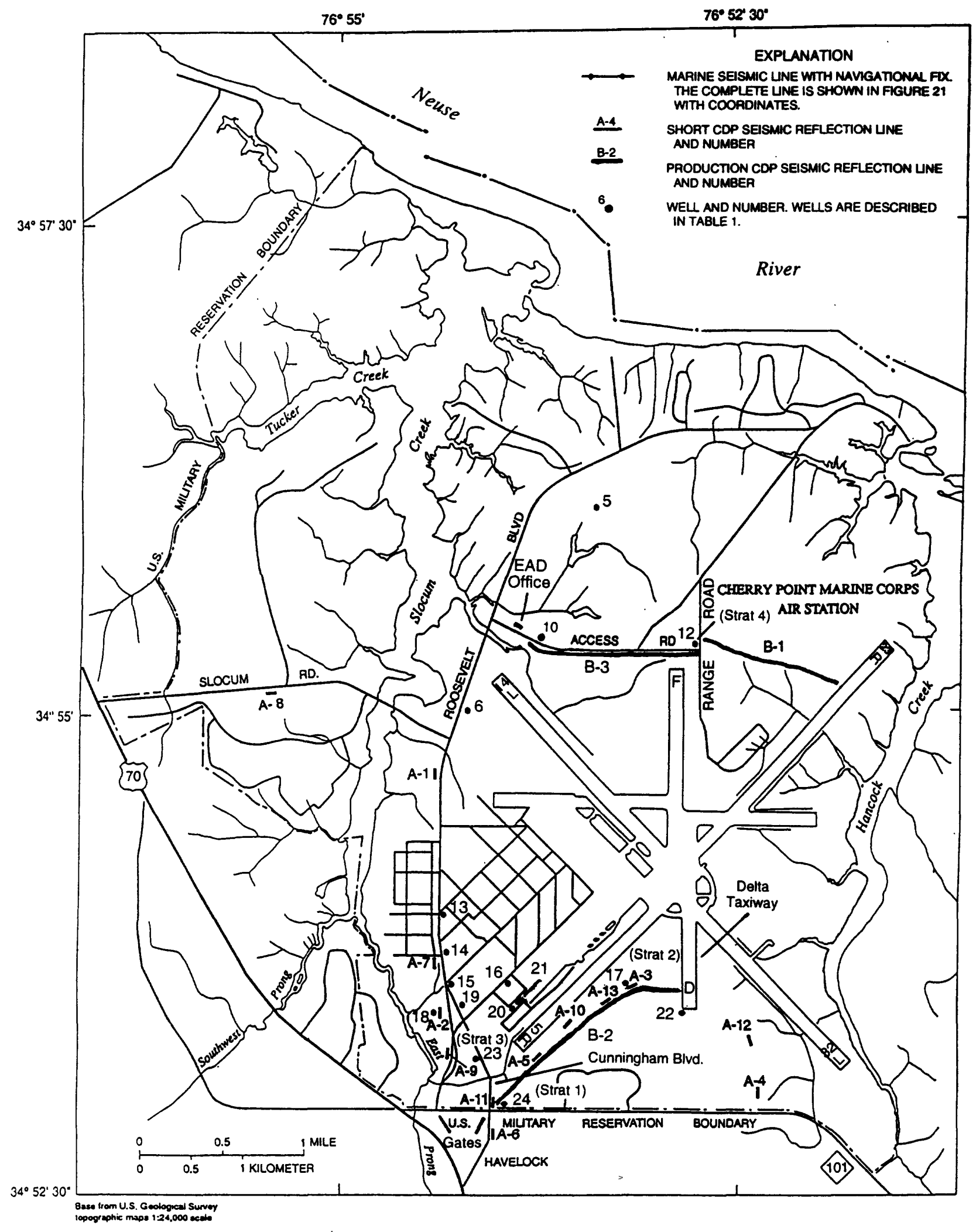

Figure 8. Location of selected wells and seismic-reflection lines, Cherry Point Marine Corps Air Station. 
고ำ 호을 os s.5.

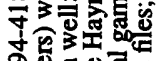

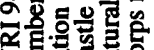
\% so

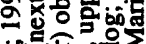

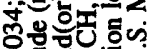
7 . oo aํ. 흘 s. o. 5.

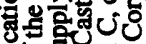

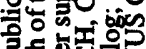

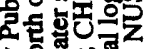

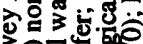

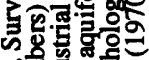
글 t). T.

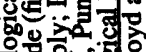

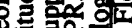
음 s.t.

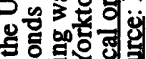
3.

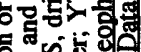
5.

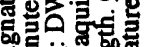
क⿹

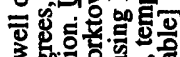

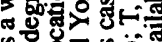

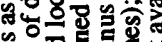

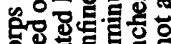
3. .

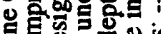

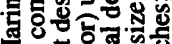

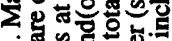
com s.

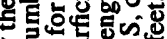
Aิ 8 .

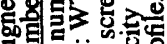
희 5.

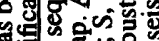

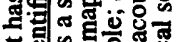
政

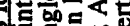
한을 을

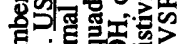
是 站的 跑 政 든

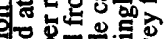

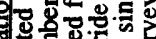

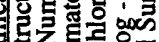
ए人 는 (5)

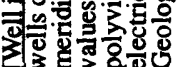

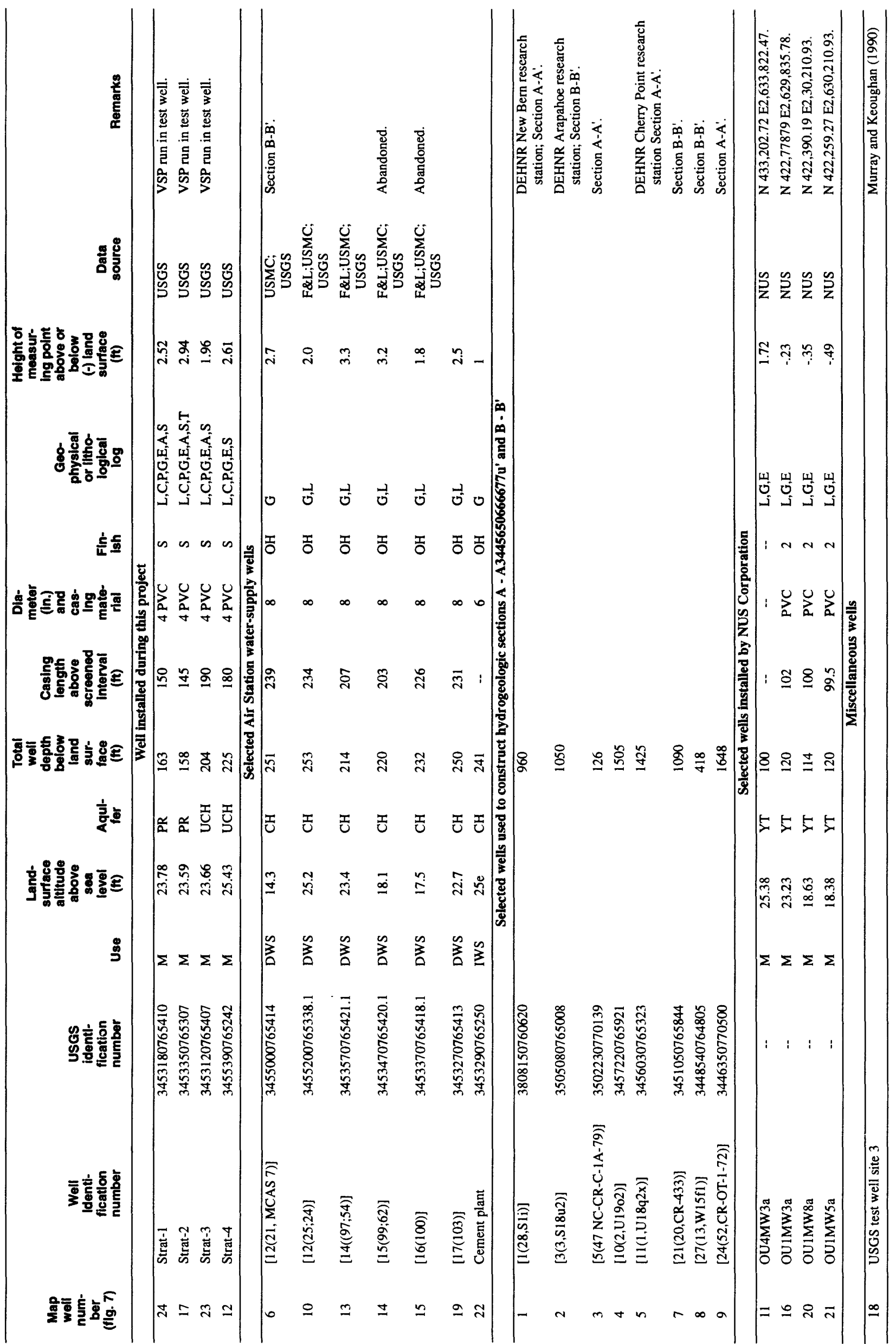


The timing and location of data-collection activities evolved during the course of the study as new data became available. The high-resolution land seismic-reflection profiling began in the southern part of the Air Station where previous work (Mixon and Pilkey, 1976; Lloyd and Daniel, 1988; Murray and Keoughan, 1990) suggested the possibility of a large paleochannel that cut through the Yorktown and Pungo River confining units. Although Mixon and Pilkey (1976) suggested that a Neuse River paleochannel crossed the Air Station in a northwest to southeast direction, the location and depth of this proposed channel did not exactly coincide with the depth and location of missing confining units at the south end of the Air Station. Other work (Hine and Snyder, 1985; Hine and Riggs, 1986) suggested that paleochannels of Pleistocene age might cross the area in directions ranging from northwest-southeast to north-south. Therefore, it was decided to run a number of short land seismic-reflection profiles in the vicinity of the known area of missing confining units in an effort to identify stratigraphic relations and extend the known area of missing confining units. A total of 13 short (approximately $240 \mathrm{ft}$ ) land seismic profiles were run in the southern part of the Air Station (fig. 8, lines A-1 to A-13). Once these profiles were run and preliminary analyses were made, stratigraphic test wells 1, 2, and 3 were drilled (fig. 8). Wells 1 and 3 were thought to be inside a large paleochannel; well 2 was considered outside of any paleochannel.

Shortly after field work on the 13 short land seismic-reflection profiles was completed, work on the marine seismic-reflection profiling began. Marine seismic lines were run in the Neuse River north of the Air Station (fig. 8), and in Slocum and Hancock Creeks. A large paleochannel complex was identified beneath the Neuse River immediately north of the Air Station. Based on the orientation and location of the marine seismic lines, it seemed likely that paleochannels identified in the profiles continued to the south beneath the Air Station. When information from the marine-seismic profiling was combined with information from previous studies, well logs from NUS Corporation, logs from the three new stratigraphic test wells, and data from the 13 short land-seismic profiles, it was hypothesized that a large paleochannel or paleochannel complex might extend across the Air Station in a north to south direction. This channel might extend south from the Neuse River, pass beneath the central part of the runway complex, beneath much of the NADEP and Facilities Maintenance area, and extend south of the Air Station beneath Havelock. This hypothesized channel orientation would be consistent with several paleochannels identified by Hine and Snyder (1985) beneath Onslow Bay (fig. 7).

In order to test the hypothesis of a large paleochannel oriented north to south beneath the Air Station, three long land seismic-reflection lines were run (fig. 8, lines B-1 to B-3). Lines B-1 and B-3 were laid out so as to completely cross the suspected paleochannel north of the runway complex. Line B-2 was laid out to cross the east flank of the paleochannel at the south end of the Air Station. This line would complement the extensive lithologic and geophysical data available from wells along Roosevelt Boulevard and other sites in the southwestern part of the Air Station. As part of this work, VSP's were run in stratigraphic test wells (Strat) 1, 2, and 3. The VSP data were needed to accurately estimate depths to reflectors from two-way travel times on the land and marine seismic profiles.

The long land seismic-reflection lines were linked to well data. Line B-2 began near the cement plant well (fig. 8, well 22) and crossed the sites of stratigraphic test wells 1 and 2 (fig. 8, wells 24 and 17 , respectively). The long land seismic-reflection line defined by lines B-1 and B-3 passed near a well drilled by NUS Corporation (fig. 8, well 11) and ended on the west near supply well 25 (fig. 8 , well 10). Because there were no well data available along line B-1 or near the east end of line B-3, stratigraphic test well 4 (fig. 8 , well 12) was drilled at the intersection of Access Road and Range Road to help link the two lines and provide data for stratigraphic interpretation of the seismic lines.

\section{Borehole Geophysical Logging}

Borehole geophysical logs were collected in each of the four new stratigraphic test wells (fig. 8; table 1). Logs were collected in the mud-filled test holes prior to installation of casing and completion of the wells. Because the logs were collected in the mudfilled holes, it was possible to collect a variety of logs that would not have been possible if the well had already been completed. The logs collected in the first three test wells were natural gamma ray, single-point resistance, focused resistivity (guard $\log$ ), spontaneous potential, acoustic velocity, caliper, and temperature. Logs collected in the fourth well were natural gamma- 
ray, single-point resistance, and spontaneous potential. The natural gamma ray, spontaneous potential, and resistance logs are perhaps the most useful for identifying lithologic units and for aiding in the interpretation and correlation of subsurface stratigraphy between wells.

The natural gamma-ray logs (sometimes called gamma logs) are records of the amount of naturally occurring gamma-ray radiation emitted by the sediments and are used to help distinguish between clayey confining material and more permeable sands. In general, clay emits more gamma radiation than does sand. The higher the gamma-ray radiation, the farther to the right is the log deflection. In sand-clay mixtures, the amount of deflection can provide a qualitative, or perhaps semi-quantitative, estimate of the amount of clay present. In the vicinity of the Air Station, apparent inconsistencies between the lithologic and gamma-ray logs are due to the presence of collophanite, a phosphate mineral found in the Yorktown and Pungo River Formations that occur beneath the Air Station (Lloyd and Daniel, 1988). This mineral emits a substantial amount of gamma radiation (Kimrey, 1965), and without corresponding lithologic logs, it is possible that phosphatic sand layers could be mistaken for clay layers on gamma-ray logs.

The single-point resistance log has been one of the most widely used in ground-water hydrology. Single-point resistance logs cannot be used for quantitative interpretations, but they are excellent for lithologic information. Single-point resistance systems measure the resistance, in ohms, between an electrode in the well and an electrode at land surface, or between two electrodes in the well. Interpretation is generally straightforward. Single-point resistance logs have a decided advantage over multielectrode logs because they do not exhibit reversals as a result of bedthickness effects; single-point resistance logs deflect in the proper direction in response to the resistivity of materials adjacent to the electrode, regardless of bed thickness; thus, they have a good vertical resolution.

Lithologies typically encountered in wells at the Air Station include limestone, sand, clay, and various mixtures of sand and clay. Locally, beds of shells, thin limestones, thin sands, and chert layers may be encountered within greater thicknesses of the other lithologies. In sediments saturated with fresh water, clays usually exhibit the least electrical resistance, limestones the greatest, and sands are intermediate. In sediments containing saline water, the resistance of all the lithologies are reduced. Partly due to the higher effective porosity of sand, the resistance of sand containing saline water is nearly as low as the resistance of clay. Limestones typically still have the highest resistance. The test wells drilled during this study all contain freshwater. Although saline water occurs beneath the Air Station in the lower Castle Hayne aquifer, none of the four test wells were drilled deeper than the upper Castle Hayne aquifer.

Spontaneous potential is one of the oldest logging techniques. It uses simple equipment to produce a $\log$ for which interpretation may be quite complex, particularly in freshwater aquifers. A spontaneous-potential log (sometimes called an SP or self-potential $\log$ ) is a record of potentials or voltages that develop at the contacts between shale or clay beds and a sand aquifer, where they are penetrated by a borehole. Spontaneous-potential measuring equipment consists of an electrode in the well connected through a voltmeter or comparatively sensitive recorder channel to a second electrode that is grounded at land surface. The spontaneous-potential electrode usually is incorporated in a probe that makes other types of logs simultaneously. Spontaneouspotential and conventional single-point resistance logs can be recorded simultaneously if a two-channel recorder is available. The same ground and down-hole electrodes are used for both logs. Spontaneous potential is a function of the chemical activities of fluids in the borehole and adjacent rocks, temperature, and type and quantity of clay present; it is not directly related to porosity and permeability. It is still standard in most logging operations to plot the resistivity and spontaneous potential logs on the same chart, with the spontaneous-potential log on the left track.

The chief limitation of spontaneous-potential logs in ground-water studies is the considerable range of salinity differences between borehole fluid and formation fluid in freshwater environments. If the borehole fluid is fresher than the native interstitial water, a negative spontaneous potential occurs opposite sand beds, which is the so-called standard response typical of oil wells. Under these salinity conditions, the spontaneous potential and single-point resistance logs will appear as mirror images when plotted on the same chart. If the salinities are reversed, the spontaneous-potential response also is reversed, producing a positive spontaneous potential opposite sand beds. Thus, the range of response possibilities is 
very large and includes zero spontaneous potential when the salinity of the borehole and interstitial fluids are the same. When the drilling mud is fresher than the formation water, the spontaneous-potential log will be similar to the gamma-ray log; under these conditions, the two types of logs can be used interchangeably for stratigraphic correlation between wells for which either the gamma-ray or spontaneous-potential log is not available.

At the Air Station, electrical logs are available only for a few wells. However, where they are available, comparisons between the electrical logs and gamma-ray logs suggest that misinterpretation of phosphatic sands as clay units is not a serious problem. This is also substantiated by information from lithologic cores and samples of cuttings. Therefore, gamma-ray logs made in existing wells at the Air Station can be used with reasonable confidence to identify sand and clay units. The water-supply wells at the Air Station are among the deepest wells there, and they provide access to the lowest parts of the freshwater system. However, many of these wells are as old as the Air Station itself, and lithologic and geophysical data are scarce or lacking for these wells. Because geophysical logs, in particular gamma-ray logs, of these wells can provide valuable information about the hydrogeology of freshwater aquifers and confining units beneath the Air Station, many of the water-supply wells at the Air Station were logged by Lloyd and Daniel (1988) during 1986-87. Electrical logs could not be run inside the metal casing of the water-supply wells, and the gamma-ray logs provide the best information about lithologies penetrated by these wells.

\section{Data Collection}

Each of the four new stratigraphic test wells was logged in the mud-filled borehole prior to installation of casing and subsequent completion of the well. Test wells 1,2 , and 3 were logged on !!:ovember 16,15, and 22, 1994, respectively, using the U.S. Geological Survey's Southeastern Region logging equipment and personnel. Test well 4 was logged on March 30, 1995 using the U.S. Geological Survey's North Carolina District logging equipment and personnel. Borehole geophysical data generally included single-point resistance, spontaneous potential, and gamma-ray logs. Guard resistivity logs and acoustic velocity were collected when the appropriate tools were available.
One or more of these logs was generated for each newly installed well. Borehole geophysical logs for the four new stratigraphic test wells drilled during this study are shown at the back of this report (figs. 9-12).

\section{Data Analysis}

Borehole geophysical log signatures of the aquifers and confining units were identified from drillers' logs, well cuttings, and lithologic descriptions (tables 2-5, at the back of report). More permeable and electrically resistive zones within the formations are defined as aquifers; extensive, finer-grained, more clay-rich, less permeable zones are defined as confining units.

Lithologic and borehole geophysical data from the newly installed wells were combined with existing data and evaluated for possible use with seismicreflection data in constructing maps and geologic sections to define the underlying structure of the Cherry Point study area. Together, these data allowed hydrogeologic sections to be drawn that more accurately depict subsurface conditions along the lines of section. Locations of newly installed wells, selected existing wells, and seismic-reflection lines used to create hydrogeologic sections are shown in figure 8 .

\section{Results}

The borehole geophysical logs (figs. 9-12), particularly the natural gamma-ray logs, were useful for correlating stratigraphy between the wells, whether lithologic data were available or not. These logs, in combination with the land seismic-reflection profiles, were used to create the hydrogeologic sections presented later in this report.

\section{Vertical Seismic Profiling}

Vertical seismic profiles (VSP's) are a highly effective way of correlating the two-way travel time seismic-reflection section with depth. VSP's have become an integral part of most petroleum exploration but have not been fully utilized for near-surface seismic surveys. The vertical seismic-profiling technique is seldom used alone, but rather is used to provide better interpretation of seismic-reflection data. Acquisition of VSP's commonly requires a string of hydrophones, 3-component geophones, or 3 -component accelerometers in a borehole, and a surface seismic source located within a few seismic wavelengths of the borehole. VSP's allow accurate 
determination of one-way travel time to various geologic units and analysis of attenuation and acoustic impedances which are needed for construction of synthetic seismograms. The synthetic seismograms are then used for comparison with seismic-reflection data to identify specific geologic formations and to refine depth estimates of those formations. References on vertical seismic profiling include Gal'perin (1974), Hardage (1983), and Balch and Lee (1984).

Vertical seismic profiling provides detailed information about reflected wavelet characteristics and travel-time approximations for a specific target interval or depth range through surface-to-borehole or borehole-to-surface acoustic measurements. (Sheriff and Geldart, 1982). The perpendicular orientation of source stations and receiver stations allows for dramatic enhancement of up-coming reflected waves without interference from down-going direct waves, tube waves, source noise, or shallow refracted waves (fig. 13). Interference from ground roll also is not present in a vertical downhole receiver configuration. After time corrections and stacking, VSP profiles possess extremely high signal-to-noise ratios. The borehole acquisitions and high signal-to-noise ratios provide for accurate correlation of stacked vertically incident reflections on CDP (common-depth point) stacked seismic profiles. The collection and processing of CDP seismic-reflection data are discussed in the next section of this report.

A VSP involves the acquisition of data with a fixed source and multiple receiver offsets (fig. 13). The wide range of azimuths this acquisition process provides allows for sufficient redundancy in stacked traces to directly correlate synthetic seismograms and CDP stacked sections. Offset VSP's require the source to be detonated at various offsets radially out from the borehole. Each shot location is recorded with either a single receiver incrementally moved through a particular interval in the borehole or with a multireceiver downhole tool. VSP's differ from velocity check shot surveys in that VSP's are designed for the recording and study of the complete waveform as well as all subsequent arrivals after the first break of incident energy. VSP's also differ from acoustic velocity logs in the configuration of source and receiver. Acoustic velocity logs generally have both the source and receiver in the borehole at the same time with a fixed separation. The VSP differs from both the surface seismic-reflection method and acoustic logging in the orthogonal orientation of source locations to receiver locations. This "right angle" profiling method allows for unique cancellation of all direct arriving waves and enhancement of any wave reflected from interfaces deeper than the receiver(s).

A single VSP seismogram recorded with multiple receiver locations and a single shot location will possess a variety of coherent linear arrivals (fig. 14-A). Unlike seismograms from surface surveys, reflection arrivals are linear. In cases with several reflecting interfaces, the arrival of down-going direct waves can easily be separated from up-going reflected waves. The intersection point of the up-going reflection with the borehole represents the depth to the reflector at the borehole. From the VSP the average velocity to depth can be determined from the arrival time of the direct wave. Vertical profiles may be time shifted by the direct wave arrival time to produce reduced vertical profiles that emphasize reflections.

The VSP seismogram for Strat-2 was time shifted and stacked (fig. 14-B) and is compared to CDP profile A-3 in figure 14-C. Well Strat-2 is located at the midpoint of CDP profile A-3. Reflections from interfaces between lithologic units identified in Strat-2 (table 3 ) are apparent in the VSP and can be correlated with reflections in profile A-3. The base of the Pungo River confining unit (clay) at a depth of 122 to $124 \mathrm{ft}$ below land surface is apparent at a two-way travel time of 50 to 54 milliseconds. The top of the River Bend Formation (limestone) at a depth of $175 \mathrm{ft}$ is a prominent reflector at a two-way travel time of 66 to 70 milliseconds. Similar comparisons were made between VSP's and CDP profiles at other locations on the Air Station to aid interpretation of the CDP profiles.

It is often apparent on VSP profiles that a number of interpretable reflections are present in intervals where the gamma log seems to suggest subtle changes in lithology, but the geologist logs quite conclusively suggest material changes. This is not uncommon considering that the natural gamma log is acquired by a radiation-sensing tool, and many sedimentary materials of the type indicated to be present on the geologist log may not initiate a response on a natural gamma log. The VSP's also allow highly accurate average velocities to be determined and approximations of interval velocities to be derived from them. Average velocities are a method to correlate time to depth independent of the source wavelet or acoustic-imaging methods. For example, they were a help in correlating time to depth on the marine seismic survey discussed in a later section of this report. 


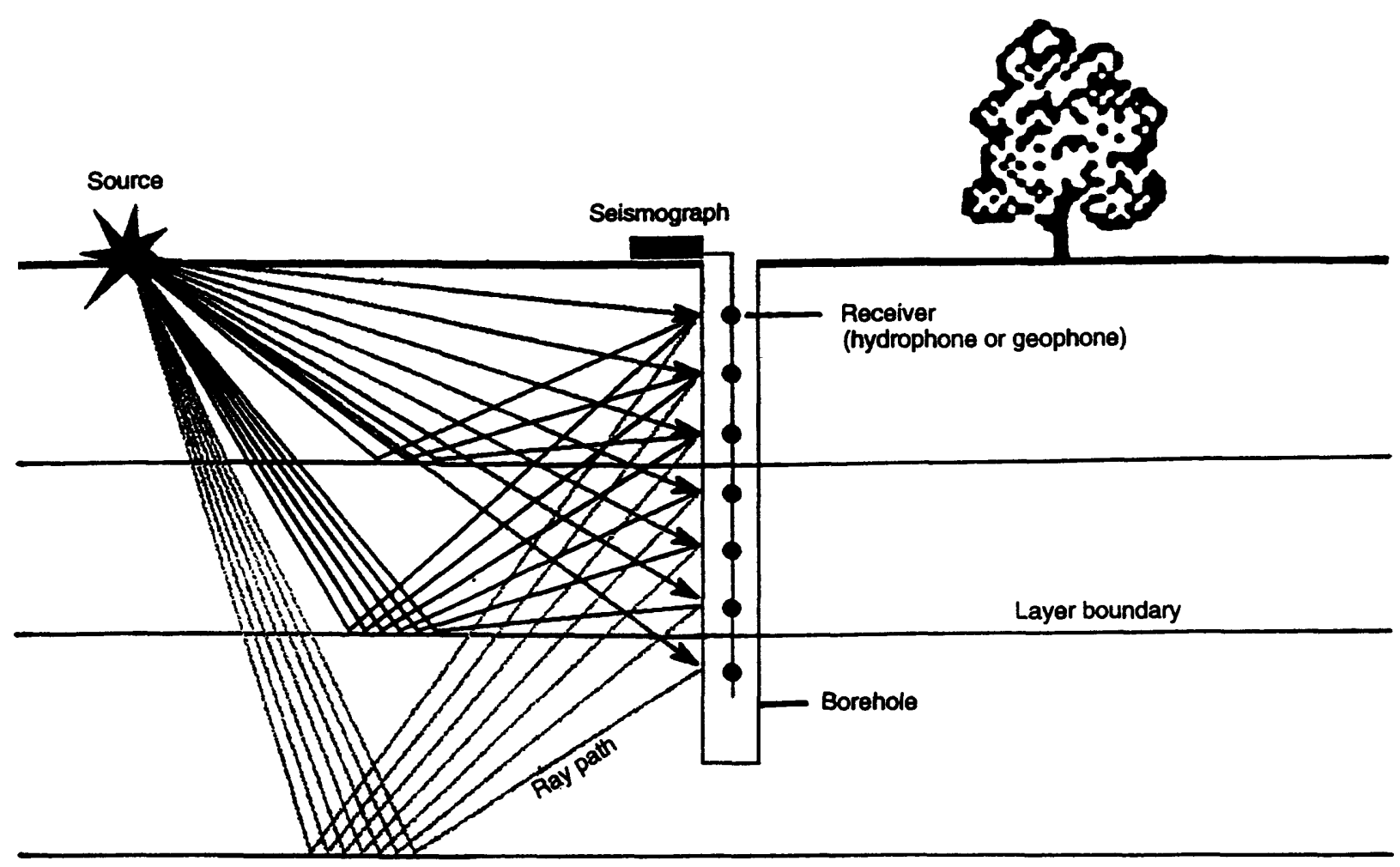

Figure 13. Schematic showing layout of source, seismograph, and receivers for conducting vertical seismic profiling in a borehole. Direct and reflected ray paths from three subsurface layer boundaries are indicated.

\section{Data Collection}

Two walkaway VSP's (one acquired with a hydrophone and the other with a holelock geophone) were recorded at each of three stratigraphic test wells--Strat-1, Strat-2, and Strat-3 (fig. 8; table 1). The locations selected for the installation of the three stratigraphic test wells were in part determined through analysis of the thirteen short CDP profiles distributed around the southern half of the Air Station. The correlation of reflectors as determined by tool depth, geologic logs, geophysical logs, and reflections recorded on VSP files with reflections on CDP stacked sections was excellent. The differences in source wavelet and attenuation are responsible for the subtle differences in the reflection wavelet character observed between the VSP profiles and CDP stacked sections.

The two different sensing tools, a holelock geophone and a hydrophone, allowed sampling of the boreholes every $5 \mathrm{ft}$ vertically while the source was walked away from the borehole. Source offsets ranged from $10 \mathrm{ft}$ to as far as $140 \mathrm{ft}$ at $10-\mathrm{ft}$ intervals. Two profiles were recorded in each hole to allow interval velocities in the saturated as well as the unsaturated zones to be determined (tables 6 and 7). To insure the several hundred shots recorded at each location would not suffer from appreciable deterioration in time zero or wavelet characteristics, a 12-lb (pound) sledge hammer was used to stack three to five shots per downhole location. Surface geophones recorded data simultaneously with each downhole receiver, allowing visual inspection of shot station to shot station as well as shot-to-shot time break and wavelet consistency. Hydrophone recording stations began approximately $10 \mathrm{ft}$ below static water level, whereas the holelock geophone recording was undertaken only in the air-filled portion of the hole. To increase overlap between hydrophone and geophone data, a portion of the water was removed from the borehole, using a packer and air-lift system. Surface source stations were evenly spaced about $10 \mathrm{ft}$ apart extending radially away from the borehole. Downhole receiver stations were consistent for all offsets and receivers and were separated by $5 \mathrm{ft}$. Hydrophone surveys started approximately $10 \mathrm{ft}$ below the piezometric surface and extended the entire length of the open borehole. The holelock geophone survey began at least $20 \mathrm{ft}$ below the piezometric surface, moving upward to the ground surface. The resulting VSP walkaway profiles allow for the interpretation of both upgoing reflections and direct travel times. Interval velocity and average velocity for each station were determined for each borehole based on first arrival interpretations of the hydrophone data. After processing the VSP data, direct time-to-depth and waveform correlation of reflections on CDP stacked sections are possible. 


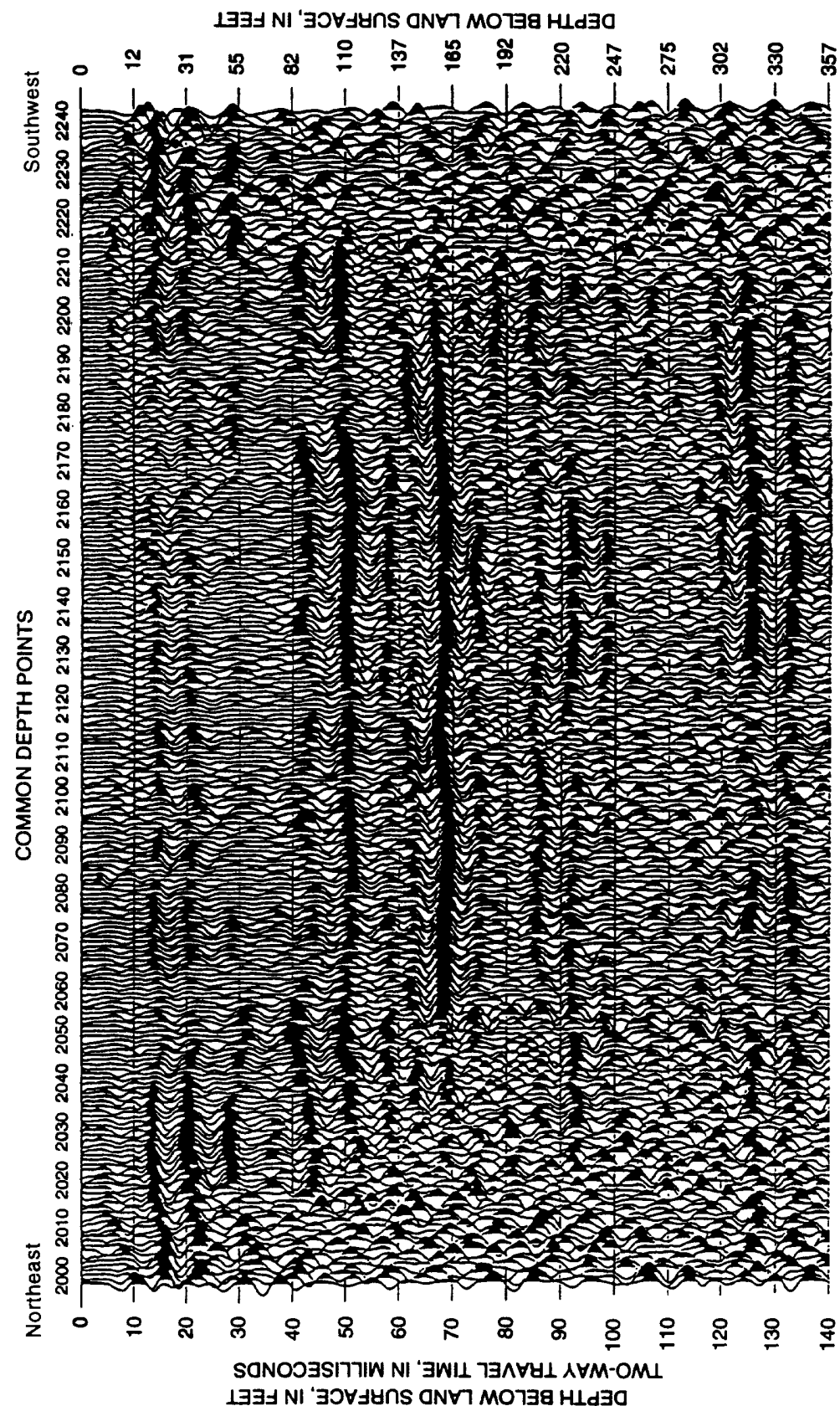

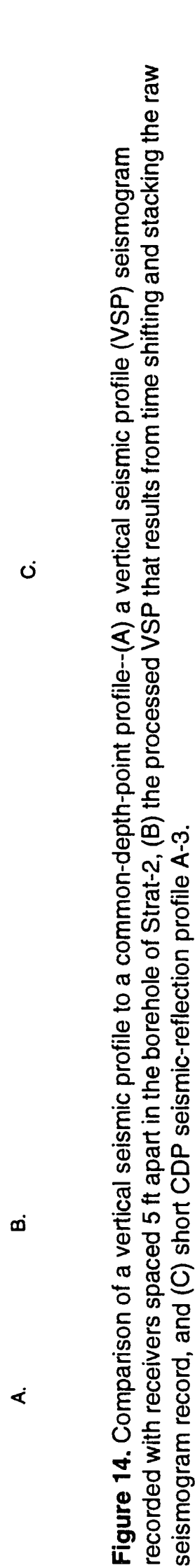


Table 6. Interval velocity from hydrophone data ${ }^{1}$

[Vertical seismic profiles (VSP) VSP 1, VSP 2, and VSP 3 were run in stratigraphic test wells Strat-1, Strat-2, and Strat-3, respectively. $\mathrm{ft}$, feet; ft/s, feet per second]

\begin{tabular}{|c|c|c|c|c|c|}
\hline \multicolumn{2}{|c|}{ VSP 1} & \multicolumn{2}{|c|}{ VSP 2} & \multicolumn{2}{|c|}{ VSP 3} \\
\hline $\begin{array}{l}\text { Depth } \\
\text { (ft) }\end{array}$ & $\begin{array}{c}\text { Interval } \\
\text { velocity } \\
(\mathrm{ft} / \mathrm{s})\end{array}$ & $\begin{array}{l}\text { Depth } \\
\text { (ft) }\end{array}$ & $\begin{array}{c}\text { Interval } \\
\text { velocity } \\
\text { (ft/s) }\end{array}$ & $\begin{array}{l}\text { Depth } \\
\text { (ft) }\end{array}$ & $\begin{array}{c}\text { Interval } \\
\text { velocity } \\
(\mathrm{ft} / \mathrm{s})\end{array}$ \\
\hline 0 to 25.0 & $2,734.525$ & 0 to 15.0 & $2,577.2$ & 0 to 25.0 & $2,354.475$ \\
\hline 25.0 to 30.0 & $3,587.875$ & 15.0 to 20.0 & $3,598.9$ & 25.0 to 30.0 & $3,360.725$ \\
\hline 30.0 to 35.0 & $5,203.8$ & 20.0 to 25.0 & $3,964.375$ & 30.0 to 35.0 & $3,958.675$ \\
\hline 35.0 to 40.0 & $4,458.95$ & 25.0 to 30.0 & $4,526.35$ & 35.0 to 40.0 & $4,069.675$ \\
\hline 40.0 to 45.0 & $6,131.6$ & 30.0 to 35.0 & $5,043.075$ & 40.0 to 45.0 & $4,981.95$ \\
\hline 45.0 to 50.0 & $4,946.65$ & 35.0 to 40.0 & $4,593.475$ & 45.0 to 50.0 & $5,695.575$ \\
\hline 50.0 to 55.0 & $6,359.05$ & 40.0 to 45.0 & $5,172.575$ & 50.0 to 55.0 & $6,313.625$ \\
\hline 55.0 to 60.0 & $5,735.75$ & 45.0 to 50.0 & $4,574.075$ & 55.0 to 60.0 & $4,685.3$ \\
\hline 60.0 to 65.0 & $5,262.475$ & 50.0 to 55.0 & $5,233.575$ & 60.0 to 65.0 & $4,939.95$ \\
\hline 65.0 to 70.0 & $4,913.175$ & 55.0 to 60.0 & $5,199.525$ & 65.0 to 70.0 & $5,074.975$ \\
\hline 70.0 to 75.0 & $5,879.125$ & 60.0 to 65.0 & $5,296.75$ & 70.0 to 75.0 & $6,212.425$ \\
\hline 75.0 to 80.0 & $6,826.375$ & 65.0 to 70.0 & $6,038.85$ & 75.0 to 80.0 & $5,065.425$ \\
\hline 80.0 to 85.0 & $5,613.95$ & 70.0 to 75.0 & $5,463.125$ & 80.0 to 85.0 & $5,833.25$ \\
\hline 85.0 to 90.0 & $5,862.775$ & 75.0 to 80.0 & $5,354.85$ & 85.0 to 90.0 & $4,950.625$ \\
\hline 90.0 to 95.0 & $7,457.725$ & 80.0 to 85.0 & $6,884.65$ & 90.0 to 95.0 & $6,610.8$ \\
\hline 95.0 to 100.0 & $4,855.25$ & 85.0 to 90.0 & $5,950.15$ & 95.0 to 100.0 & $6,085.5$ \\
\hline 100.0 to 105.0 & $5,358.8$ & 90.0 to 95.0 & $6,487.55$ & 100.0 to 105.0 & $5,178.8$ \\
\hline 105.0 to 110.0 & $6,557.45$ & 95.0 to 100.0 & 4,630 & 105.0 to 110.0 & $8,426.55$ \\
\hline 110.0 to 115.0 & $9,706.6$ & 100.0 to 105.0 & $4,763.675$ & 110.0 to 115.0 & $6,439.2$ \\
\hline 115.0 to 120.0 & $5,824.875$ & 105.0 to 110.0 & $4,939.875$ & 115.0 to 120.0 & $8,900.45$ \\
\hline 120.0 to 125.0 & 6,188 & 110.0 to 115.0 & $6,025.4$ & 120.0 to 125.0 & $5,581.9$ \\
\hline 125.0 to 130.0 & $5,546.45$ & 115.0 to 120.0 & $6,164.85$ & 125.0 to 130.0 & $5,211.1$ \\
\hline 130.0 to 135.0 & $7,988.325$ & 120.0 to 125.0 & $5,990.5$ & 130.0 to 135.0 & $6,026.675$ \\
\hline 135.0 to 140.0 & $7,368.075$ & 125.0 to 130.0 & $6,102.1$ & 135.0 to 140.0 & $7,800.375$ \\
\hline 140.0 to 145.0 & $8,509.025$ & 130.0 to 135.0 & $5,779.375$ & 140.0 to 145.0 & $6,015.225$ \\
\hline 145.0 to 150.0 & $7,273.75$ & 135.0 to 140.0 & $6,104.025$ & 145.0 to 150.0 & $5,574.375$ \\
\hline 150.0 to 155.0 & $5,731.5$ & 140.0 to 145.0 & $6,861.675$ & 150.0 to 155.0 & $5,967.5$ \\
\hline \multirow[t]{9}{*}{155.0 to 160.0} & $7,869.55$ & 145.0 to 150.0 & $7,484.95$ & 155.0 to 160.0 & $8,704.975$ \\
\hline & & 150.0 to 155.0 & $6,048.925$ & 160.0 to 165.0 & $6,171.65$ \\
\hline & & & & 165.0 to 170.0 & $7,643.775$ \\
\hline & & & & 170.0 to 175.0 & $7,207.675$ \\
\hline & & & & 175.0 to 180.0 & $9,802.05$ \\
\hline & & & & 180.0 to 185.0 & $5,024.175$ \\
\hline & & & & 185.0 to 190.0 & $9,346.95$ \\
\hline & & & & 190.0 to 195.0 & $8,219.8$ \\
\hline & & & & 195.0 to 200.0 & $5,954.875$ \\
\hline
\end{tabular}

1 The relative error in the interval velocity may be as high as 15 percent; for example, the interval velocity from 0 to $25 \mathrm{ft}$ in VSP 1 is $2,734.525 \mathrm{ft} / \mathrm{s}$, which should be interpreted as $2,734.525 \mathrm{ft} / \mathrm{s}$ plus or minus $410 \mathrm{ft} / \mathrm{s}$. 
Table 7. Interval velocity from geophone data ${ }^{1}$

[Vertical seismic profiles (VSP) VSP 1, VSP 2, and VSP 3 were run in stratigraphic test wells Strat-1, Strat-2, and Strat-3, respectively. ft, feet; $\mathrm{ft} / \mathrm{s}$, feet per second]

\begin{tabular}{|c|c|c|c|c|c|}
\hline \multicolumn{2}{|c|}{ VSP 1} & \multicolumn{2}{|c|}{ VSP 2} & \multicolumn{2}{|c|}{ VSP 3} \\
\hline $\begin{array}{l}\text { Depth } \\
\text { (ft) }\end{array}$ & $\begin{array}{l}\text { Interval } \\
\text { velocity } \\
\text { (ft/s) }\end{array}$ & $\begin{array}{l}\text { Depth } \\
\text { (ft) }\end{array}$ & $\begin{array}{c}\text { Interval } \\
\text { velocity } \\
\text { (ft/s) }\end{array}$ & $\begin{array}{l}\text { Depth } \\
\text { (ft) }\end{array}$ & $\begin{array}{l}\text { Interval } \\
\text { velocity } \\
\text { (ft/s) }\end{array}$ \\
\hline 0 to 5.0 & $2,576.9$ & 0 to 5.0 & $2,546.1$ & 0 to 5.0 & $2,393.5$ \\
\hline 5.0 to 10.0 & $2,534.4$ & 5.0 to 10.0 & 2,670 & 5.0 to 10.0 & $2,498.9$ \\
\hline 10.0 to 15.0 & $2,685.5$ & 10.0 to 15.0 & $2,851.35$ & 10.0 to 15.0 & $2,786.5$ \\
\hline 15.0 to 20.0 & $2,936.6$ & 15.0 to 20.0 & $3,529.55$ & 15.0 to 20.0 & $3,036.4$ \\
\hline \multirow[t]{4}{*}{20.0 to 30.0} & $2,994.9$ & 20.0 to 25.0 & $4,009.3$ & 20.0 to 25.0 & $3,693.6$ \\
\hline & & 25.0 to 30.0 & $3,901.55$ & 25.0 to 30.0 & $3,653.45$ \\
\hline & & 30.0 to 35.0 & $4,531.05$ & 30.0 to 35.0 & $4,569.7$ \\
\hline & & & & 35.0 to 40.0 & $5,207.5$ \\
\hline
\end{tabular}

1 The relative error in the interval velocity may be as high as 15 percent; for example, the interval velocity from 0 to $5 \mathrm{ft}$ in VSP 1 is $2,576.9 \mathrm{ft} / \mathrm{s}$, which should be interpreted as $2,576.9 \mathrm{ft} / \mathrm{s}$ plus or minus $386 \mathrm{ft} / \mathrm{s}$.

\section{Data Analysis}

The VSP data are processed to enhance correlation of geologic contacts determined in wells with reflections interpreted on CDP stacked sections. The processing of VSP data is very straightforward. In this case, the single-channel data are sorted into common source locations (which in appearance and for most practical purposes are equivalent to multichannel data) where the upcoming reflections are extracted through slope filtering. After a static correction is made for nonvertical travel path, the data are corridor stacked. Corridor stacking is simply a summing process of all vertically incident corrected traces with a common source location. Final working display of VSP data resembles synthetic seismograms allowing direct overlay of the vertically incident VSP with a CDP stacked section. Incorporating the time-to-depth relations, determined by first arrival analysis of unprocessed VSP data, with the overlay of the processed VSP data with the CDP stacked section permits high confidence correlation of reflections on CDP data with reflectors identified in the borehole.

\section{Results}

The walkaway VSP's were designed to allow accurate designation of two-way travel time from the ground surface to reflectors of interest and to provide a wiggle trace representation of the reflectivity sequencing of the wells (fig. 15). The wiggle trace display allows accurate correlation of reflection wavelets with discrete acoustic boundaries and with lithologic boundaries interpreted from lithologic as well as borehole geophysical logs (fig. 15). Sampling with two tools (a hydrophone and a holelock geophone) was necessary to provide a continuous velocity profile from the ground surface to total depth of each borehole. Sufficient overlap (redundancy in measurements at or near the water table surface) between the two tools was provided to insure accurate values in the transition zone. Because of a lack of saturation above the water table, and therefore poor casing to borehole coupling, the holelock geophone data were not as high in quality as data from hydrophones. Average velocity curves were determined from the interval velocity data given in tables 6 and 7. The average velocity data were used to estimate two-way acoustic travel times at different depths (table 8) so that depths to reflectors on the seismic profiles can be determined.

The primary focus of the uphole survey was to acquire average velocity and a VSP for each borehole. Therefore, the data set is not optimum for interval velocity. With the 1/4-ms (millisecond) sampling interval used to acquire these data, the interval velocity between any two stations possesses an error range of about 25 percent. 


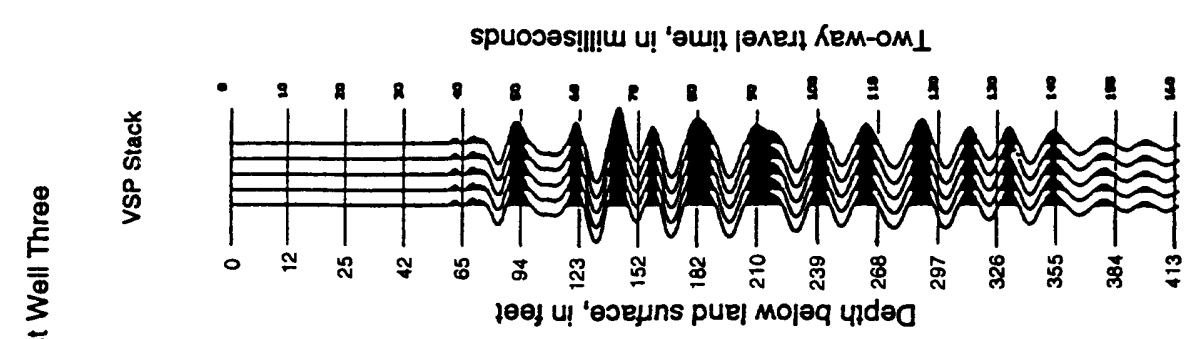

$\dot{\infty}$

๖

苛

品

을

元

깅요

- के

$\cong$.

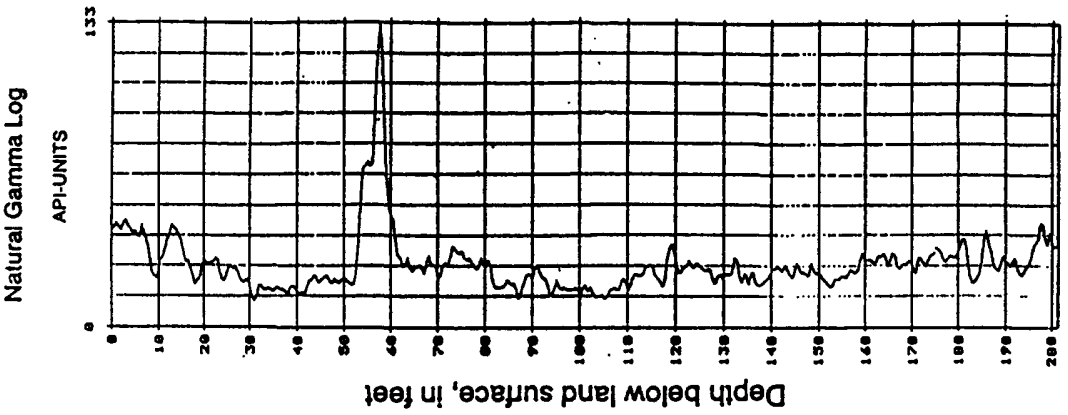

क्ष

3 우은

屯

문

응

진

응

진 은

동ㅇㅇ

응응

음

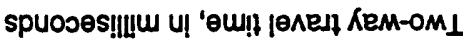

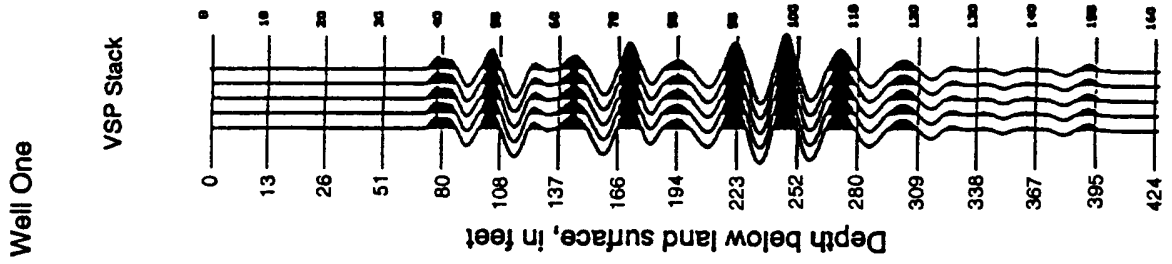

过

要

(ิ)

心 응

$\sum \underset{\sigma}{0}$

은 등

응

.0

的施

边 응

历ำ

는 읃드

事

은 등

के :

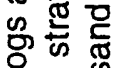

을

들 屯

jeə] u! 'өoejuns pue| Mo|eq yideO

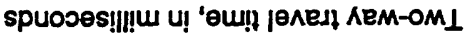

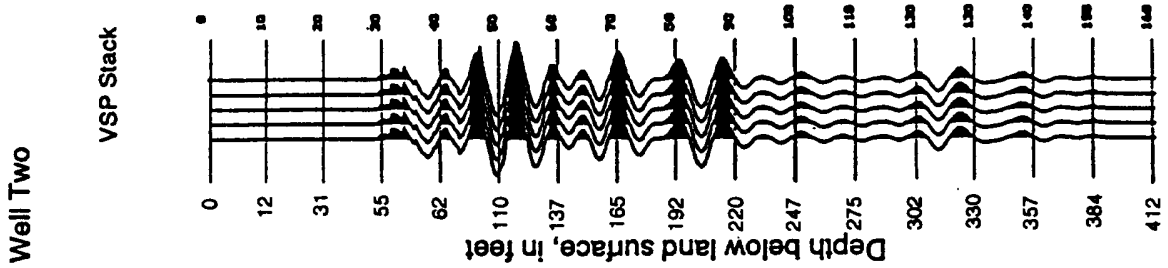

픙

ญ

宁芒至

동호

잉도

응 홍

তٓ

吾过

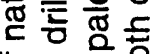

ㄴㅇㅇ웡

ㄷํㅇำ

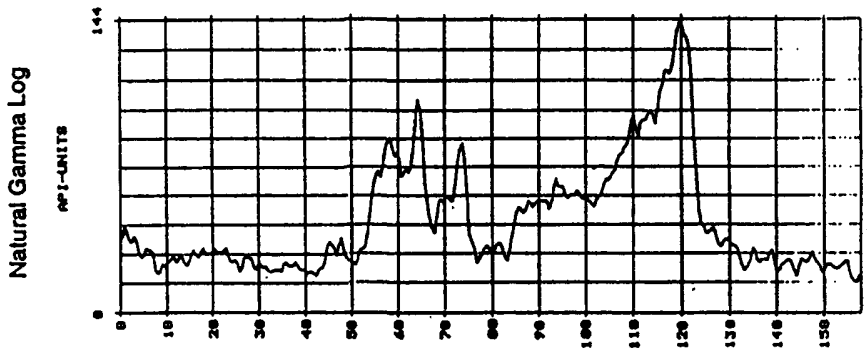

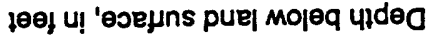

유

을 등 은

응흘웡

เ

․ㅡ 음

ฏ

宁征 둥

뉸 
Table 8. Two-way acoustic travel time at 5-foot intervals of depth between land surface and the bottoms of stratigraphic test wells 1 , 2 , and 3

[VSP, vertical seismic profile; $\mathrm{ft}$, feet; $\mathrm{ms}$, milliseconds]

\begin{tabular}{|c|c|c|c|}
\hline \multirow[b]{2}{*}{ Depth (ft) } & \multicolumn{3}{|c|}{ Two-way travel time (ms) } \\
\hline & VSP 1 & VSP 2 & VSP 3 \\
\hline 5 & 3.8 & 3.9 & 4.2 \\
\hline 10 & 7.8 & 7.7 & 8.2 \\
\hline 15 & 11.6 & 11.6 & 12.1 \\
\hline 20 & 14.9 & 14.7 & 15.7 \\
\hline 25 & 18.2 & 17.3 & 20.2 \\
\hline 30 & 21.3 & 19.6 & 23.2 \\
\hline 35 & 23.4 & 21.6 & 26.0 \\
\hline 40 & 25.7 & 23.9 & 28.5 \\
\hline 45 & 27.5 & 26.0 & 31.7 \\
\hline 50 & 29.6 & 28.2 & 33.7 \\
\hline 55 & 31.2 & 30.2 & 35.4 \\
\hline 60 & 33.0 & 32.1 & 37.7 \\
\hline 65 & 34.9 & 34.0 & 39.9 \\
\hline 70 & 37.0 & 35.7 & 42.0 \\
\hline 75 & 38.8 & 37.6 & 43.7 \\
\hline 80 & 40.3 & 39.5 & 45.7 \\
\hline 85 & 42.1 & 41.0 & 47.6 \\
\hline 90 & 43.9 & 42.7 & 49.6 \\
\hline 95 & 45.3 & 44.3 & 51.2 \\
\hline 100 & 47.4 & 46.4 & 53.0 \\
\hline 105 & 49.3 & 48.6 & 55.0 \\
\hline 110 & 50.9 & 50.7 & 56.2 \\
\hline 115 & 52.3 & 52.4 & 57.9 \\
\hline 120 & 54.1 & 54.2 & 59.2 \\
\hline 125 & 55.9 & 55.9 & 61.1 \\
\hline 130 & 57.8 & 57.6 & 63.1 \\
\hline 135 & 59.3 & 59.4 & 64.8 \\
\hline 140 & 61.4 & 61.0 & 66.2 \\
\hline 145 & 62.6 & 62.5 & 67.9 \\
\hline 150 & 64.2 & 64.0 & 69.8 \\
\hline 155 & 66.0 & 65.7 & 71.7 \\
\hline 160 & 67.3 & & 72.9 \\
\hline 165 & & & 74.0 \\
\hline 170 & & & 76.1 \\
\hline 175 & & & 77.6 \\
\hline 180 & & & 78.9 \\
\hline 185 & & & 81.0 \\
\hline 190 & & & 82.5 \\
\hline 195 & & & 84.2 \\
\hline 200 & & & 86.1 \\
\hline
\end{tabular}




\section{High-Resolution Land Seismic-Reflection Profiling}

Shallow, high-resolution land seismic-reflection techniques possess the resolution potential necessary to delineate paleochannels as well as correlate stratigraphy from well to well across the Air Station. Shallow land surveys have been successfully employed elsewhere to image a shallow bedrock surface (less than $300 \mathrm{ft}$ deep) as well as overlying unconsolidated sequences (Miller and others, 1986; Birkelo and others, 1987; Jongerius and Helbig, 1988; Miller and others, 1989; Pullan and Hunter, 1990; Goforth and Hayward, 1992). However, for the purpose of accurately correlating two-way travel times to reflections on CDP stacked sections with geologic contacts encountered in boreholes, the effectiveness and importance of collecting VSP's during shallow surveys (less than $300 \mathrm{ft}$ deep) has only recently begun to become apparent (Schieck and Pullan, 1995). Incorporation of VSP's, borehole geophysical logs, and lithologic logs with marine and land seismic-profile data provide the most accurate and horizontally continuous representation of the stratigraphy at this site.

Seismic-reflection surveys routinely involve three basic parts: acquisition, processing, and interpretation of seismic data. The basic instrument for seismic studies is a seismograph, which is analogous to a stereo system that can record as well as play acoustic recordings. A seismograph has variable controls for amplifying and selectively enhancing recorded sound frequencies. Selection of the frequencies to be enhanced and the amplifier gain necessary to maximize the relevant recorded information depends on the depth and size of the underground geologic features of interest and the acoustic properties of the earth material. As a general rule, low frequencies are used for exploration at great depth, and high frequencies are used at shallow depth. A seismograph that can record and enhance high frequency sound waves is necessary to detect small geologic features. The use of high frequency seismic waves [greater than $80 \mathrm{~Hz}(\mathrm{Hertz})$ ] in reflection seismology is known as "high resolution" seismic exploration (Sheriff, 1991).

Receivers for detecting reflected acoustic signals in the ground are called geophones. These are very specialized microphones similar in principle to those used in voice recording. Selection of the appropriate geophone for a particular survey is based on the dominant frequency and amplitude of the signal.

The simplest case of seismic reflection is a single layer over an infinitely thick medium such as bedrock and the boundary between the two provides an acoustical discontinuity (fig. 16). A source of seismic waves emits energy into the ground, commonly by explosion, mass drop, or projectile impact. Energy is radiated spherically away from the source. An arbitrarily large number of ray paths can be traced out from the seismic energy source. However, one particular ray path originating at the source will direct energy to a subsurface layer, reflect from that subsurface layer and return as an echo to the geophone at the surface first, following Fermat's principle of least travel time.

In the real world, there are commonly several layers beneath the earth's surface that are within reach of the seismic-reflection technique (fig. 17). Note that figure 17 is a simplification because ray paths are in general not straight lines, but are deflected at velocity discontinuities (boundaries between layers) according to Snell's law. For multiple layers the angle of incidence between rays and layers is different for each layer, but the reflecting points are vertically equivalent. The fact that several layers often contribute to seismograms tends to make the seismic data more complex because reflections from greater depths arrive at later times than shallow reflections. Complexity often also is increased by the presence of seismic energy that has bounced one or more times between layers in the subsurface (multiple reflections).

Source and receiver locations can be placed so that path $S_{1}-R_{2}$ reflects from the same location in the subsurface as path $S_{2}-R_{1}$ (fig. 18). The subsurface point that is in common for both source and receiver pairs is variously called a common reflection point (CRP) (Mayne, 1962), a CDP, or a common midpoint (CMP), depending on the preference of the author.

The power of the CDP method is in the redundancy in sampling of a particular subsurface location. By gathering traces in a computer according to CMP, traces with the same CMP can be added to enhance the reflection signal. Before this addition can take place, however, the data must be corrected for differences in traveltime for the reflected waves caused by the differences in source-to-geophone distance. The degree of redundancy or multiplicity of data at a particular point is known as "CDP fold." A 24-channel seismograph, for example, is typically used to gather 12-fold CDP data. From a theoretical standpoint, signalto-noise ratio of reflections improves proportionally to the square root of the CDP fold.

The purpose of acquiring and processing seismicreflection data in a CDP format is to enhance reflections at the expense of everything else. There are a variety of filtering, display and static correction techniques that can be employed to improve the quality of the reflections. The fundamentals of CDP processing are discussed by Waters (1987), Yilmaz (1987), and Robinson and Trietel (1980). 


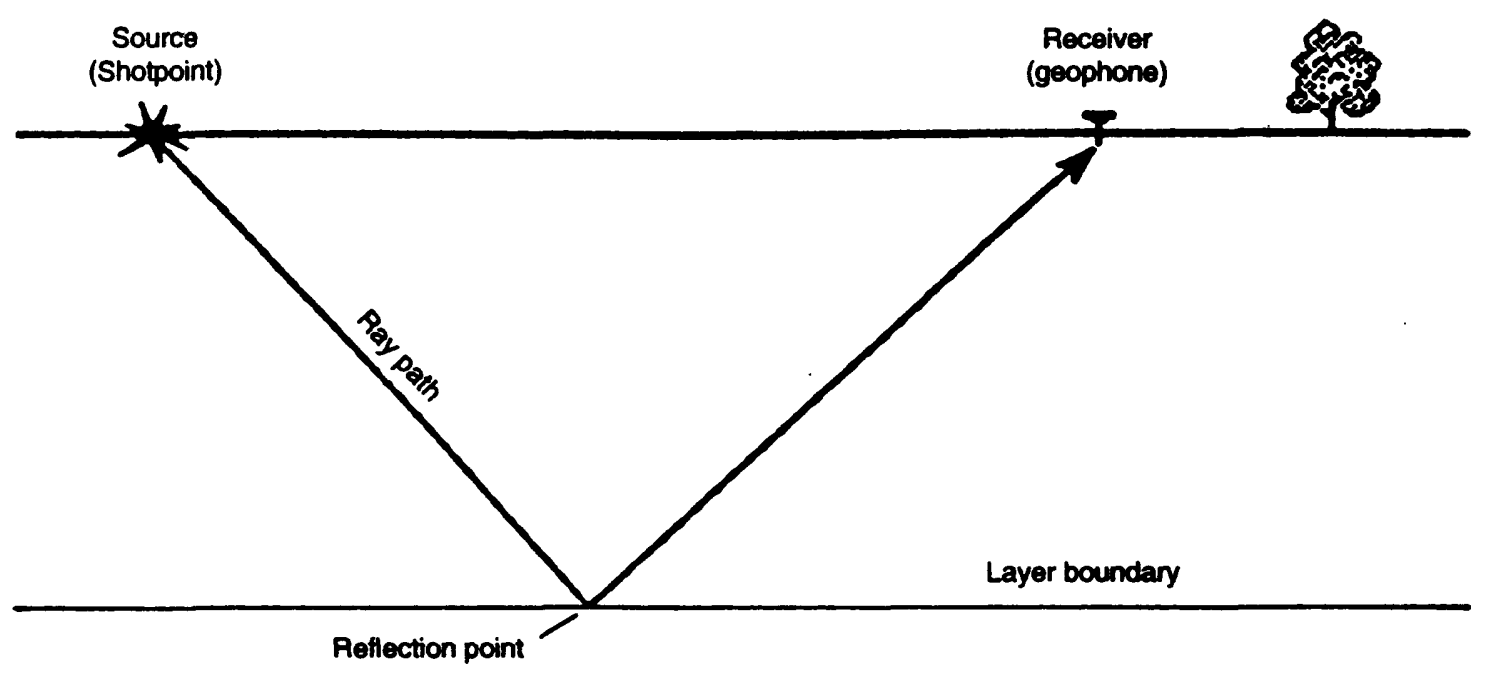

Figure 16. Reflection from one subsurface layer boundary. The angle of incidence of the downgoing ray is equal to the angle of reflectance of the upgoing ray.

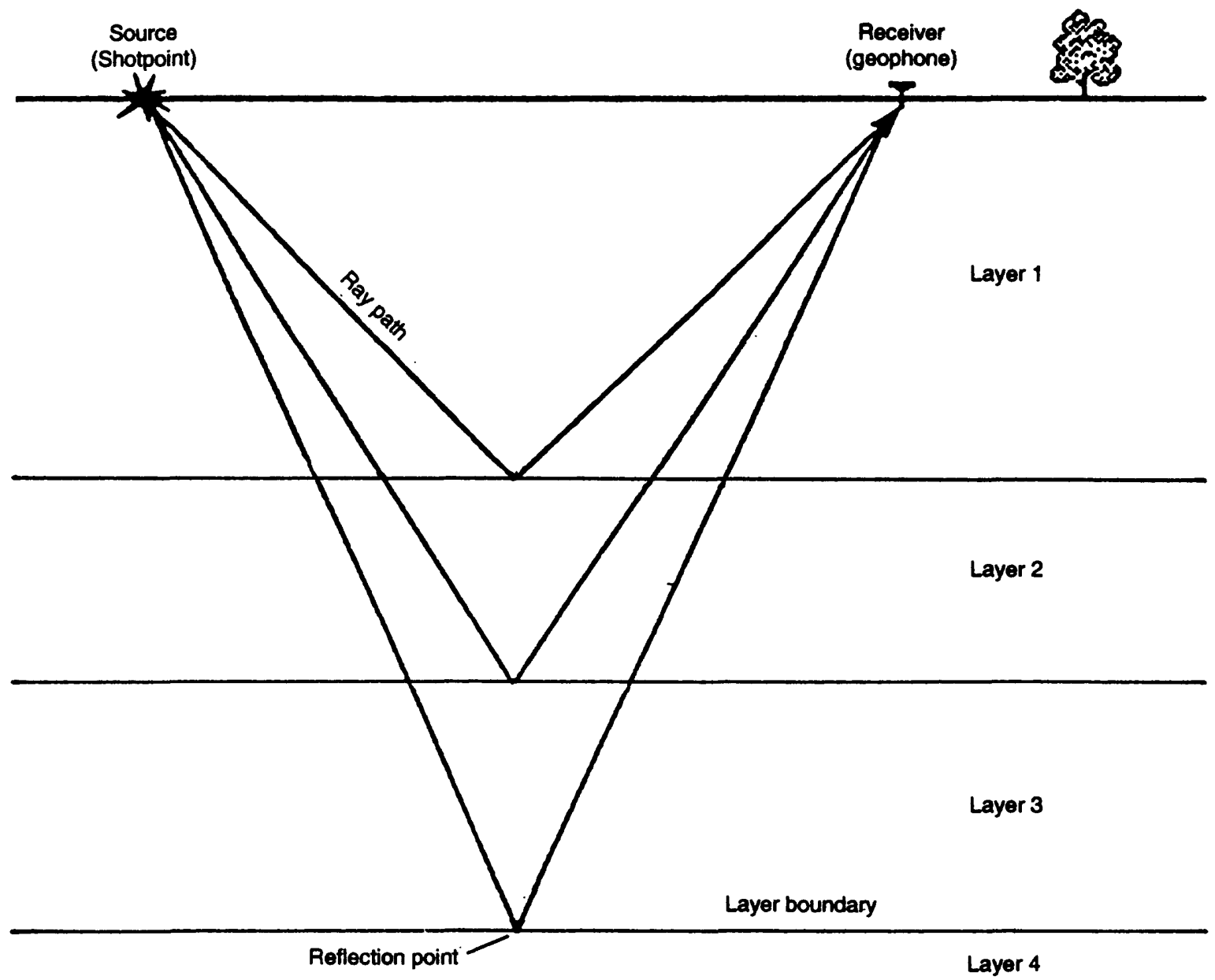

Figure 17. Reflection from three subsurface layer boundaries. The angle of incidence at the layer boundaries is different for each ray, but the reflection points are vertically equivalent. 


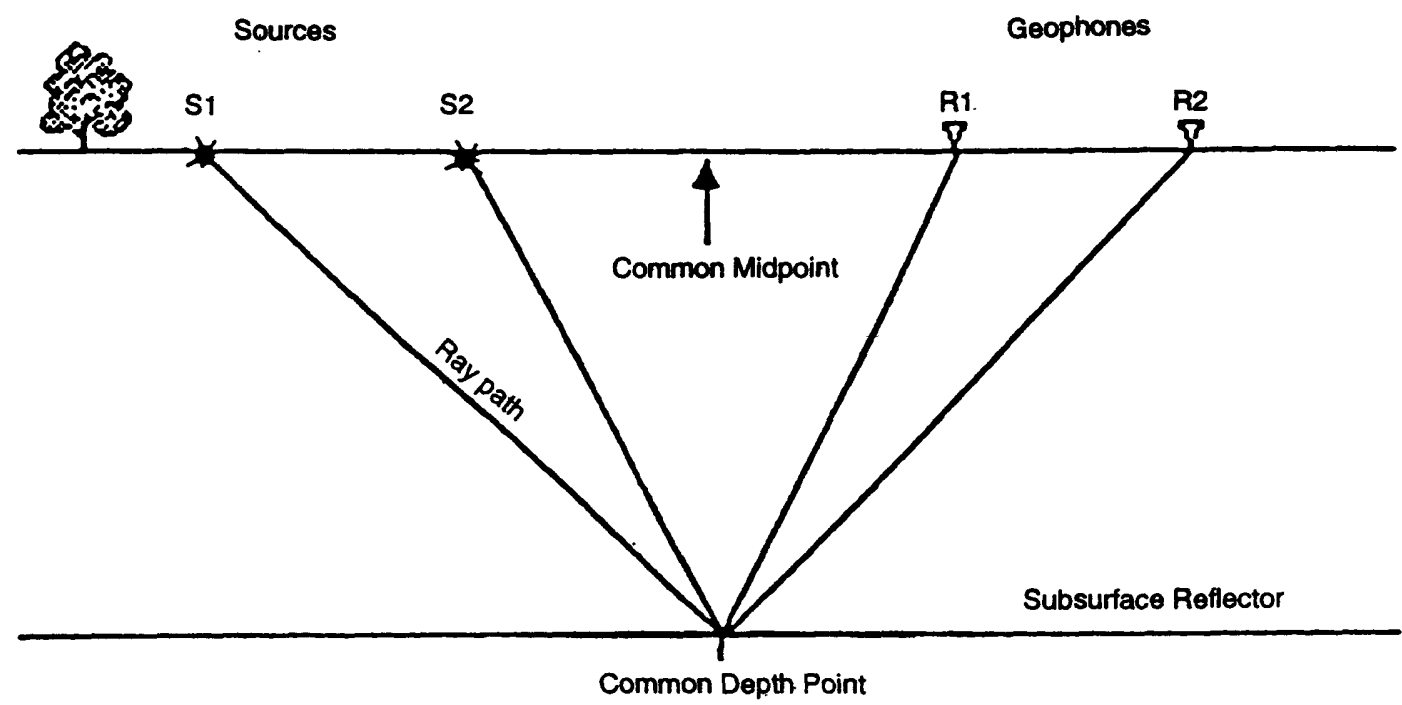

Figure 18. The concept of common-depth-point. Note that ray paths from two different shotpoints $\left(S_{1}\right.$ and $\left.S_{2}\right)$ reflect from a common point in the subsurface.

Seismic-reflection data are almost always displayed relative to two-way travel time, which can be converted in a general sense to depth if velocity is known. The accuracy of the conversion of a time seismic-reflection section to a depth geologic cross section depends on how well the average velocity from the surface to each reflector is known. The wiggles on a reflection seismogram represent amplitude of an echo that arrived at the geophone at a particular time. That time, when multiplied by the average seismic velocity within the earth, equates to twice depth. If the travel time of an acoustic pulse from the surface to a variety of depths in the subsurface can be determined from borehole geophones, conversion of time to depth can be very accurate. Vertical seismic profiling in boreholes is one means of acquiring acoustic traveltime data to make these conversions.

The seismic-reflection method is generally used to determine the spatial configuration of underground geological interfaces. Displaying all the CDP stacked traces consistent with their spatial locations results in a time-reflection cross section of a portion of the earth (fig. 19). The peaks of the seismic reflections (wiggles or wiggle trace) are generally blackened to assist in interpretation. The schematic example (fig. 19) is a very simple version of typical near-surface geology that depicts a buried clay lens in a river valley. Resolving a fixed-size target becomes more difficult with increasing depth below the ground surface, but the physical principles remain the same.

\section{Data Collection}

This land seismic-reflection program required two site visits, one during September 19-26, 1994, and another during January 26-February 6, 1995 (Miller and others, 1995). The site visit in September 1994 included the acquisition of 13 short CDP lines (totaling. 1,971 shotpoints) (fig. 8), walkaway noise tests (including $31 \mathrm{P}$-wave and $15 \mathrm{~S}$-wave spreads), and two velocity check shot surveys (19 offset versus depth records). The walkaway noise tests and velocity check shot surveys were undertaken at two sites--one outside the interpreted trace of the paleochannel (line A-1) and one inside the paleochannel (line A-2) (fig. 8). In accordance with the best information available at the time, the thirteen short CDP lines were deployed liberally around the southern and southwestern parts of the Air Station in hopes of discriminating the reflection signature of sediments within the proposed paleochannel from those outside. Data acquired during the first visit assisted in the selection of locations for the three stratigraphic test wells which, in conjunction with the marine seismic-reflection survey, were instrumental in line selection and planning data acquisition and equipment design for the three long CDP profiles (totaling 2,065 shotpoints) and the VSP traces (combining a total of 1,445 offset versus depth 


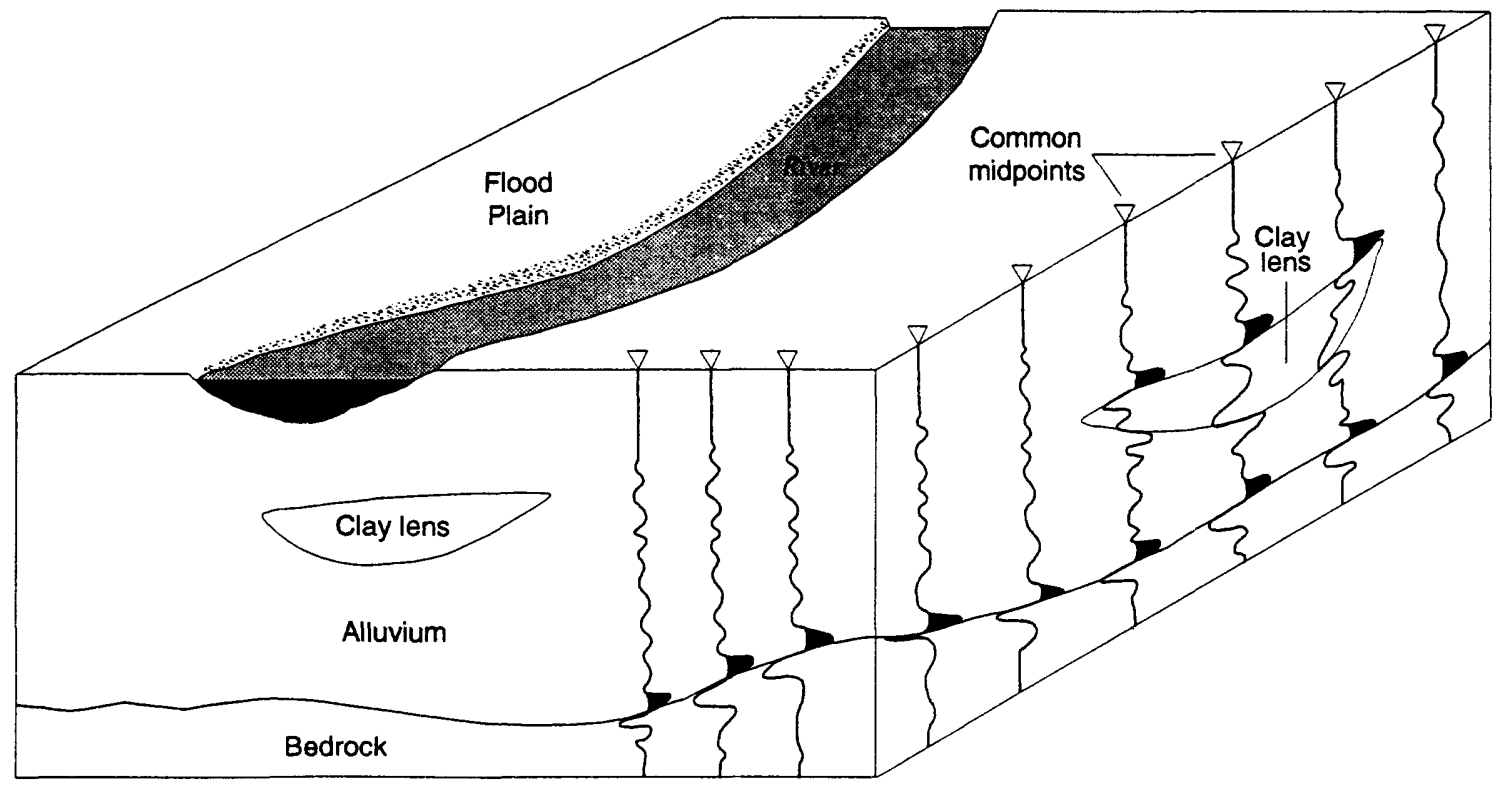

Figure 19. Schematic showing a conceptual land seismic-reflection profile relating to real-world, threedimensional geology. The geology is interpreted from coherent blackened peaks on the seismic section. Seismic data are processed to emulate what they would look like if the shotpoints and geophones were located at the same point (common midpoint) on the earth's surface (adapted from Steeples and Miller, 1990). 
records) collected during the second visit. The intersection of the CDP survey lines with the stratigraphic test wells (sites of VSP profiles) dramatically enhanced both the accuracy and confidence in correlating reflections with reflectors.

Several different types of acoustic surveying methods and techniques were employed to image geologic contacts (and other acoustic interfaces) at depths between 30 and $300 \mathrm{ft}$ as accurately as possible. The thirteen 24-fold, 240-ft CDP lines were acquired in such a way as to utilize both the redundancy of the CDP method (Mayne, 1962) and efficiency of single-point data. The three VSP's (collected in stratigraphic test wells 1-3) were acquired primarily to allow accurate time-to-depth conversion of reflections interpreted on the stacked sections; the presence of key reflections also allows full-wave form correlation to the CDP stacked-reflection wavelets. The three 12 -fold seismic-reflection profiles with line lengths of 7,100 linear $\mathrm{ft}$ (line B-2), 4,800 linear $\mathrm{ft}$ (line B-3), and 4,760 linear $\mathrm{ft}$ (line B-1) (fig. 8) were acquired in a roll-along fashion to delineate channels inferred from other data as efficiently as possible. The integration of the various acoustic methods with the borehole-derived geology greatly enhanced the continuity of the subsurface image.

During the September 1994 trip, data were recorded with a diverse set of equipment to insure that the optimum equipment configuration was selected for the long production lines. All data acquired for this portion of the study were recorded on a 48-channel Geometrics 2401X seismograph. This seismograph amplifies, filters (analog), digitizes the analog signal into a 15-bit word, and stores the digital information in a demultiplexed format. Analog filters have an 18-dB (decibel)/octave roll-off from the selected $-3 \mathrm{~dB}$ points. A 1/5-ms sampling interval resulted in a 200-ms record with a 2,500-Hz Nyquist frequency. The 13 short CDP sections were acquired with a $1,000-\mathrm{Hz}$ high-cut and a 200-Hz low-cut analog filter. The analog low-cut filter was necessary to properly shape the spectrum, allowing maximum resolution possible for signals generated at this site (Steeples, 1990). The very sitedependent nature of acoustic source characteristics (Miller and others, 1994) prompted comparison of three types of compressional wave sources, including the 30.06-caliber downhole rifle (projectile), the 12-gauge auger gun (downhole explosive), and both 12-lb and 20-lb sledge hammers (weight drop). Based on the signal-to-noise ratio, resolution potential (bandwidth, dominant frequency, and corner frequency), and power spectrum, the 30.06-caliber downhole rifle was chosen as the optimum source for this study. Single $100-\mathrm{Hz}$ and triple $40-\mathrm{Hz}$ geophones were compared and evaluated, and the single $100-\mathrm{Hz}$ geophone was selected for the study.

Guided by the results of walkaway testing and the uphole check shot survey, the initial 13 compressional wave CDP data sets were recorded using a 120-station fixed spread, a station spacing of 2 $\mathrm{ft}$, and the 30.06-caliber downhole source moved through the spread on the half intervals. The results from this initial visit proved invaluable to the overall quality, economics, and consistency of data collected during the second visit.

The three 12-fold CDP production profiles and the three VSP's were acquired during the January 1995 visit. Parameters and equipment were optimized based on the processed and analyzed results of the September trip. The seismograph used to record data from this trip was a 48-channel Geometrics StrataView. The StrataView amplifies and digitizes the analog signal into a 21-bit word, and stores the information in a demultiplexed format. The significant increase in dynamic range eliminated the need for a severe analog low-cut filter. Spectral analysis of data recorded with each seismograph confirmed that the effective bandwidth and upper-corner frequency of the reflection data after digital filtering was not adversely affected by not recording with the analog low-cut on the StrataView. Analysis of reflection data recorded on the first trip supported maintaining a sampling interval of $1 / 4 \mathrm{~ms}$ and a record length of $250 \mathrm{~ms}$ or greater. Field geometries were modified from the initial visit to maximize production without reducing the resolution potential of the CDP stacked sections. The 30.06caliber downhole rifle source and $100-\mathrm{Hz}$ geophones were deployed in an asymmetric split-spread sourcereceiver configuration with a nominal source-tonearest receiver distance of $10 \mathrm{ft}$ and farthest receiver offset of $150 \mathrm{ft}$. Receivers were spaced on 4-ft stations and shotpoints were spaced on 8-ft stations at the midpoint between receivers. The greater dynamicrange seismograph allowed for improved postacquisition flexibility with respect to spectral shaping. The StrataView also allowed for high speed QA/QC (quality assurance/quality control) as a result of the nearly real-time digital-filtering capabilities. Everything considered, the testing and stratigraphic analysis of the data acquired on the first trip greatly improved the scope of the seismic project, allowing for improved correlation to geology as well as an increase in signal-to-noise ratio, resolution potential, and the horizontal coverage per unit cost. 


\section{Data Analysis}

The seismic-reflection data from this study were processed on an Intel 80486-based microcomputer using Eavesdropper, a set of commercially available algorithms (Somanas and others, 1992). Display parameters were determined based on the scale of existing data sets, optimum exaggerations, and workable formats. During this study, the only operations or processes used were those that enhanced the signal-to-noise ratio and(or) resolution potential as determined by correlation of reflections with stratigraphic data from wells.

For most basic shallow high-resolution seismicreflection data, processing steps for CDP data are a simple scaling down of established petroleum industrybased processing techniques and methods (Yilmaz, 1987; Steeples and Miller, 1990). The processing flow was similar to that used for routine petroleum exploration. The main distinctions relate to the conservative use and application of correlation statics, the level of precision required during velocity and spectral analysis, and the accuracy of the muting operations. A very low (by conventional standards) allowable normal moveout (NMO) stretch, less than 20 percent, was extremely critical in minimizing contributions from the very shallow reflected energy at offsets significantly beyond the critical angle. Limiting wavelet stretch through muting maximizes resolution potential and minimizes distortion in the stacked wavelets (Miller, 1992). Variability in depth to the first refracting horizon was as much as $10 \mathrm{~ms}$ across a single CDP stacked section. This depth variability was very effectively compensated for with a form of refraction statics. Processing steps and processes used on these data were carefully executed with no prior assumptions regarding the seismic signature of the geologic section. Extreme care was taken to enhance, through processing only, what could be identified on raw data and not to create coherency on stacked sections where none was obvious on the field records.

\section{Results}

Locations of the 13 short CDP lines were carefully selected to determine the consistency in reflection characteristics, the depth to major reflectors, the distribution and geometries of all reflections, the signal-to-noise ratio at various places around the base, and extremes of resolution potential along planned long CDP profiles (fig. 8). Line-to-line correlation of coherent reflection arrivals with similar wavelet characteristics and within particular time windows can be accomplished with reasonably good success. However, there is no geophysical basis for suggesting continuity of reflectors based on apparent correlation of line-to-line reflections; in fact, in this Coastal Plain geologic setting, an assumption of that nature would likely result in misinterpretation of the hydrogeologic model. The short CDP lines that produced the best quality data were lines A-3, A-5, A-6, and A-8 (fig. 8). The dominant frequency of the best stacked reflections is around 180 to $200 \mathrm{~Hz}$. Considering the reflection characteristics of the four higher quality lines, the practical vertical resolution of long CDP profiles should be around 5 to $8 \mathrm{ft}$, and the horizontal resolution, based on the square root of the radius of the first Fresnel zone, should be about $20 \mathrm{ft}$ at $80 \mathrm{ft}$ of depth.

CDP line A-7 (fig. 8) possesses some of the most interesting reflection geometries. The reflectors between 20 and $75 \mathrm{~ms}$ are interpreted to show an erosional (cut-and-fill) feature with truncated bedding that could represent the edge of a paleochannel that is wider than imageable with this line. Time ties from line-to-line produce a reasonable correlation at opposite ends of the section and might imply that reflections are from the same units, until consideration is given to the gently dipping reflector (apparent dip to the south) that crosses the entire profile between $35 \mathrm{~ms}$ on the north end and $55 \mathrm{~ms}$ on the south end and truncates bedding both above and below this reflector. Thus, it is reasonable to suggest that the $45 \mathrm{~ms}$ reflector on the north end is older than the $45 \mathrm{~ms}$ reflector on the south end of the section. This section also contains an interesting example of a bed termination between CDP's 2,127 and 2,165 (between 254 and $330 \mathrm{ft}$ from the north end of the line). A feature that appears to be a northward-dipping reflector changes from $45 \mathrm{~ms}$ to $63 \mathrm{~ms}$ (approximately 95 to $145 \mathrm{ft}$ deep) across a distance of only $76 \mathrm{ft}--\mathrm{a}$ very steep slope for a coastal environment. This feature is apparently an artifact created by reflections from a bed termination (Fresnel effect) against the bottom of the paleochannel.

Reflection geometries suggest that the north end of the section is oriented toward the northern margin of an infilled channel sequence. The top of the limestone in the River Bend Formation is easily recognized in the interval between 75 and $80 \mathrm{~ms}$ (approximately $180 \mathrm{ft}$ deep). 
The three long CDP profiles represent the focus of the shallow land seismic-reflection effort to image a paleochannel proposed to extend south from the paleochannel identified beneath the Neuse River (fig. 8) to an area of missing confining units identified in widely spaced wells and boreholes at the southern end of the Air Station. Two of the CDP lines (B-1 and B-3) are north of the runway complex and are divided by Range Road (fig. 8). The coverage extends east along the south side of Access Road from near the EAD (Environmental Affairs Department) office to Range Road and from Range Road east along a gravel road to the northern end of runway 23 . The third and longest line (B-2) extends east from the south end of taxiway $\mathrm{D}$ (Delta taxiway) near the asphalt plant to stratigraphic test well 2, where the line turns to the southwest and follows a gravel road roughly parallel to runway 5 to a point near Cunningham Boulevard and approximately $150 \mathrm{ft}$ north of the offices at the Cunningham Boulevard gate (fig. 8). The lines were deployed to intersect the trace of the proposed paleochannel at as oblique an angle as possible. The lines were located in areas with minimal chances of human disturbance, maximum near-surface saturation, minimum cultural noise, and maximum information potential. Analysis of factors that contributed to the excellent data obtained on short CDP lines A-3, A-5, A-6, and A-8 were incorporated in order to optimize the line locations.

Analysis of interference phenomena, reflection geometries, and wavelet characteristics of CDP line B-1 (easternmost of the two northern lines, fig. 8) lacks any evidence that would indicate the presence of a major paleochannel between the limestone of the River Bend Formation and within about $30 \mathrm{ft}$ of the ground surface. The CDP stacked section possesses excellent coherence on three reflections above the Castle Hayne Limestone. Using a general velocity function derived from the three VSP's conducted on the southern end of the base (table 8), the shallowest reflection is from about 40 to $50 \mathrm{ft}$ ( 25 to $30 \mathrm{~ms}$ ) and is probably the Yorktown confining unit. The second coherent reflection is interpreted to be about 90 to $110 \mathrm{ft}$ deep ( 45 to $50 \mathrm{~ms}$ ) and is probably the Pungo River confining unit (which serves as the upper Castle Hayne aquifer confining unit beneath the Air Station). The next sequence of events is within the Miocene Pungo River portion of the section. Identification of this time section as Miocene assumes the entire section between the River Bend and the unconfined aquifer is present. Based on base-wide lithology, the Pungo River units should be present in the interval from about 100 to 180 $\mathrm{ft}$ deep. The portion of the section between the Pungo River confining unit and the limestone of the River Bend Formation ( 110 to $180 \mathrm{ft}$ ) appears to be riddled by scour and infill sequences with little or no section-wide consistency in bedding. Along the western half of line B-1, westward dipping sequences between about 110 . and $180 \mathrm{ft}$ below land surface are likely indicative of changes in stream channels, shorelines, and(or) local drainage. The top of the limestone of the River Bend Formation is continuous with only subtle topographic features. A reflection at about $95 \mathrm{~ms}$ equates to a reflector at about $240 \mathrm{ft}$ and is likely the boundary between the River Bend Formation and Castle Hayne Limestone. With the exception of the cut and fill features present between about 110 and $180 \mathrm{ft}$ of depth, the seismic-reflection section suggests only subtle thickness and possibly a few subtle stratigraphic changes across the entire $0.9-\mathrm{mi}$ section.

The approximately $0.9-\mathrm{mi}$ seismic profile acquired in the road ditch along the south side of Access Road (CDP line B-3, fig. 8) possesses a great deal of data variability as a result of near-surface conditions and reflector geometry changes. The most dramatic discontinuity on this line occurs around 2,950 $\mathrm{ft}$ west of Range Road near the EAD office. This dramatic change in reflection geometries and characteristics is suggestive of a major lithologic or structural change. In this case, it is most likely the abrupt change is related to a major channel feature. The eastern part of CDP line B-3 is acoustically similar to CDP line B-1; time also ties very well to CDP line B-1. A VSP in stratigraphic test well 4 (well 12, fig. 8) located at the intersection of Access Road and Range Road would provide a valuable link between the seismic profile and lithologies as determined from samples and geophysical logs. In the absence of a VSP for test well 4, correlating the western part of CDP line B-3 with the VSP from stratigraphic test well 2 indicates that the three prominent reflections interpreted as the Yorktown confining unit, Pungo River confining unit and the River Bend Limestone are present at nearly the same depths. Several subtle cutand-fill features can be interpreted within the Pungo River portion of the section. With the image of the subsurface provided by seismic lines B- 1 and B-3, it is not possible to determine which or if either part of line 
$\mathrm{B}-3$, as defined by the discontinuity near the EAD office, is within the trace of a paleochannel. It is apparent, based on the geophysical logs from watersupply well 24 and stratigraphic test well 4 (fig. 8; table 1), that the two thick clays (considered Yorktown and Pungo River confining units) in well 24 are thicker and the tops higher than the two thick clays identified in test well 4. The top of the presumed Yorktown confining unit is $10 \mathrm{ft}$ higher and the top of the presumed Pungo River confining unit is $18-20 \mathrm{ft}$ higher in well 24 . There is also a shallow clay between land surface and about $16 \mathrm{ft}$ in supply well 24 that is not indicated on the natural gamma log for test well 4.

The long seismic line B-2 intersects both stratigraphic test wells 1 and 2, allowing lithologic, borehole geophysical log, and VSP correlations to coherent reflections. Lithologic interpretations of test well 2 suggest the top of the Yorktown confining unit is present at a depth of about 45 to $55 \mathrm{ft}$, which correlates to a 25- to $30-\mathrm{ms}$ reflection. There is no obvious reflector in this interval. The next significant unit (at least in terms of the natural gamma logs) is the 100 to 120 -ft deep clay (45- to 50-ms reflection), which is thought to be the lower part of the Pungo River confining unit. Based on the assumption that this borehole is within a complete part of the geologic section, the portion of the time section between the Pungo River confining unit (approximately $45 \mathrm{~ms}$ ) and the River Bend Formation (approximately $80 \mathrm{~ms}$ ) is of Miocene age. Within the time section between about 50 and $80 \mathrm{~ms}$ are a complex set of horizontally varying small channel sequences. The very consistent and relatively flat-lying River Bend Formation is interpreted at about $80 \mathrm{~ms}(180 \mathrm{ft})$, and equally flat and uniform is the $95-\mathrm{ms}$ ( $240 \mathrm{ft}$ ) unconformity that separates the River Bend Formation (upper Castle Hayne aquifer) from the Castle Hayne Limestone (lower Castle Hayne aquifer).

Similar to CDP line B-3, there is an abrupt discontinuity in reflectors about $2,500 \mathrm{ft}$ northeast of stratigraphic test well 1 . It is interesting to note that there are similarities between the discontinuity on this line, CDP line B-3, and the short CDP line A-7. It is not unreasonable to suggest that these discontinuities in the two clay layers could be either related or at least representative of a similar geologic process or sequence. The dramatic change in reflection characteristics and general geometries apparent across the discontinuity on line B-2 could represent the most important hydrogeologic feature along this line.
Within the Miocene (Pungo River) part of the section, the geometries of the cut-and-fill features and overall channel fill sequences are consistent with features and geometries within the Miocene section on marine seismic profiles collected just off-shore in Onslow Bay (Hine and Riggs, 1986). The deeper of these channels is cut into the shell and sand layer (155 to $180 \mathrm{ft}$ ) at the base of the Pungo River Formation, and may even cut through this layer into the top of the River Bend Formation.

Several features along this section (B-2) are of particular interest and could have some bearing on the hydrologic properties of the section above the Castle Hayne Limestone. However, it appears that the River Bend has not been subjected to sufficient scouring to have breached the isolation between the River Bend Formation and Castle Hayne Limestone (upper and lower Castle Hayne aquifers) provided by the lower Castle Hayne confining unit.

On the other hand, the apparent erosional truncation of the Pungo River confining unit (identified in stratigraphic test well 2 between depths of 80 and $120 \mathrm{ft}$ ) at several locations along line B-2 is strong evidence of the dangers of well-to-well correlations in this setting. If stratigraphic test well 2 were to have been drilled $600 \mathrm{ft}$ east or $2,100 \mathrm{ft}$ southwest of its current location, a completely different picture of the trace of the proposed paleochannel might well have been implied from well data alone. The 110-ft clay seems to thicken just before erosional truncation at CDP 510 by a channel that, based on the lack of internal reflections, may be analogous to the channel proposed to be present at stratigraphic test well 3. The channel feature interpreted from the CDP stacked section to be present between CDP's 470 and 630 (between 480 and $1120 \mathrm{ft}$ southwest of stratigraphic test well 2) is likely full of a single type of material and, in this particular case, it is very possible this would be identified as a series of sands with minor discontinuous clays and shell layers if encountered during drilling.

A more speculative interpreted geometry is related to a sequence of flat-lying beds just north of the major discontinuity observed about $2,500 \mathrm{ft}$ northeast of stratigraphic test well 1 . This sequence of flat-lying beds continues for about $550 \mathrm{ft}$ to the northeast and could be interpreted as somewhat of a division between two clearly unique depositional settings. Structures interpreted northeast of this sequence of flat-lying beds appear to represent multiple sequences of cut and fill 
followed by the deposition of a single consistent reflector likely in a very low energy setting. Structures interpreted south of this sequence of flat-lying beds possess very little geometry and are likely the result of uniform deposition, possibly the result of a later and more extensive episode of stream erosion and later infilling.

Interpretations of reflections on CDP stacked sections suggests that horizontal correlation from well to well of units shallower than the River Bend Formation (limestone) is not possible in this part of the Coastal Plain with well data only. The variability previously noted in marine seismic data nearby is consistent with the apparent structures noted within the Miocene portion of the section (Hine and Riggs, 1986). The Yorktown and Pungo River confining units identified on many geologist and geophysical logs from boreholes around the Air Station may not always be the same stratigraphic units. The variability in log characteristics and geologists' descriptions of these units is consistent with the suggestion based on the seismic data that most apparent bedding within the upper $180 \mathrm{ft}$ possesses limited horizontal extent. The discontinuities noted along lines B-2, B-3, and line A7 are similar, not only in approximate depth but also in the general character of the features. Extra care was taken to insure that these features were not the result of processing artifacts or interpretive cycle skipping. The most convincing piece of evidence that refutes any suggestion that these features are artifacts is the horizontal continuity and lack of any time offset or interference by the shallow discontinuity on the River Bend Formation and Castle Hayne Limestone along seismic-reflection line B-2. With the exception of an interpreted minor scour at about CDP 880 (about 2,100 $\mathrm{ft}$ southwest of stratigraphic test well 2), the limestones of the upper and lower Castle Hayne aquifers show little or no apparent structure across more than $1 \mathrm{mi}$ of seismic line. The complex series of cut-and-fill features are consistent with identifications in logs of multiple shell layers, stringers, and lenses in most boreholes. The reflections, as interpreted on the CDP stacked sections, present an image of the subsurface consistent with the borehole-defined lithology. At the same time, these reflections suggest that the multiple unique aquifer and confining-unit sequences, previously suggested to be uniformly present across the Air Station (with the exception of a major paleochannel which was the target of this study), may be an oversimplification of the geology.

\section{High-Resolution Marine Seismic-Reflection Profiling}

Continuous marine seismic-reflection profiling of Slocum Creek, Hancock Creek, and the Neuse River north of the Air Station was conducted to collect data for use in describing the structural and depositional setting of the hydrogeologic units overlying the Castle Hayne aquifer. Continuous marine seismic-reflection profiling provides a means of studying the structure of rocks and sediments beneath water-covered areas and is limited to water bodies. The continuous, singlechannel, seismic-reflection profiling system used for this study provided virtually continuous record of reflected seismic echoes in the upper $150 \mathrm{ft}$ of compacted sediment beneath a hard river bottom. Poorer quality data were obtained to depths of about $300 \mathrm{ft}$. In areas where the bottom sediment is soft, typically organic rich, and gassy, the energy from the acoustic source was absorbed, resulting in little or no penetration of the underlying dense sediment. Thus, data collected in these areas were not applicable to the goals of this study.

In general, the hydrogeologic system beneath the Air Station is a multi-layered medium with nearly horizontal layering. Because individual layers with different lithologies have different velocity and density contrasts, part of the seismic-wave front generated by an acoustic source will be reflected back from each layer interface. The number of interfaces reflecting energy to the surface and the strength of the returned echo depend on the power and frequency spectrum of the source, the velocity-density contrast at the interfaces, and scattering, spreading, and absorption losses within the medium itself. Horizontal resolution is determined by firing rate, vertical resolution by the returned frequency, and depth by source type and strength.

The reflection produced by a layered boundary is a function of the acoustic impedance. Both unconsolidated and consolidated units within the section have different densities and sound wave propagation speeds. Each medium is characterized by its acoustic impedance, which is the product of the density of the medium multiplied by the velocity of the sound wave through it:

$$
z=d v
$$

where $z$ is acoustic impedance, $d$ is density, and $v$ is velocity. The amount of energy reflected depends on 
the contrast in acoustic impedance on both sides of an interface and is defined by the reflection coefficient:

$$
R=\frac{d_{2} v_{2}-d_{1} v_{1}}{d_{2} v_{2}+d_{1} v_{I}}
$$

where $R$ is the reflection coefficient, $d_{1}$ and $d_{2}$ and $v_{1}$ and $v_{2}$ are densities and propagation speeds (acoustic velocities), respectively, of adjacent layers or stratigraphic units. Reflection coefficients of typical geologic boundaries are presented in table 9 (Sylwester, 1983). The higher the value of R, the greater the amount of energy that will be reflected, and the more likely that the interface will be detected in the seismic record.

The necessary quality, extent, and resolution of continuous seismic-reflection recording depend on the purpose of the study. Degrading factors within the medium are dispersion, selective frequency filtering in sediments and rocks, attenuation (especially by soft and(or) gassy sediments) side echoes, multiples, and scattering. Other factors include limitations and nonlinearity of the amplifiers and filters, signal-tonoise ratio of the cable used, the quality of the acoustic signal, and the response of the hydrophones.

In a typical continuous marine seismic survey, a boat is equipped with either a hull-mounted or towed sound source that pulses at regular intervals as the boat travels along a selected course. A receiver (hydrophone) or groups of receivers (streamer cables) towed behind the boat pick up the reflected echoes. The relation of the acoustic paths (ray paths) to the acoustic source, reflecting surfaces, and hydrophones are shown in figure 20 . The depth to a reflector can be computed if the velocity of the wave front is known. The end result is a time section, which represents the two-way travel time of the seismic-wave front from the sound source to a reflector and back to the hydrophones placed in the streamer cables. This time section provides continuous representation of the reflectors beneath the vessel. A more detailed discussion of the principles of seismic-reflection profiling can be found in Dobrin (1976), Telford and others (1976), and Sylwester (1983).

\section{Data Collection}

Continuous seismic profiling requires a (1) rapid-pulse sound source, (2) hydrophone or groups of hydrophones (streamer cable) to receive reflected signals, (3) signal processor to amplify and filter the hydrophone output, and (4) graphic recorder to record and display the reflection profile. A magnetic tape recording of the raw, unfiltered signal is usually made for subsequent playback and analysis. An on-board navigation system is needed for accurate position location. A diagram of a typical seismic profiling system is shown in figure 20 .

Prior to this study, very little was known about the acoustical properties of the bottom sediments of the Neuse River, Slocum Creek, or Hancock Creek. It was known that the bottom sediments varied a great deal among the three bodies of water. Along the south shore of the Neuse River there is a wave-cut bench between the shoreline and the deeper central channel that has a hard bottom with only isolated patches of soft sediment and little aquatic vegetation. The water depth on this bench varies from $0 \mathrm{ft}$ at the shore to a maximum of 6 to $7 \mathrm{ft}$ at the edge of the central channel. The average depth is 3 to $4 \mathrm{ft}$. Typically, the edge of the central channel is several hundred feet offshore. Once past the edge of the central channel, water depth increases rapidly to depths of 12 to $15 \mathrm{ft}$. The bottom of the

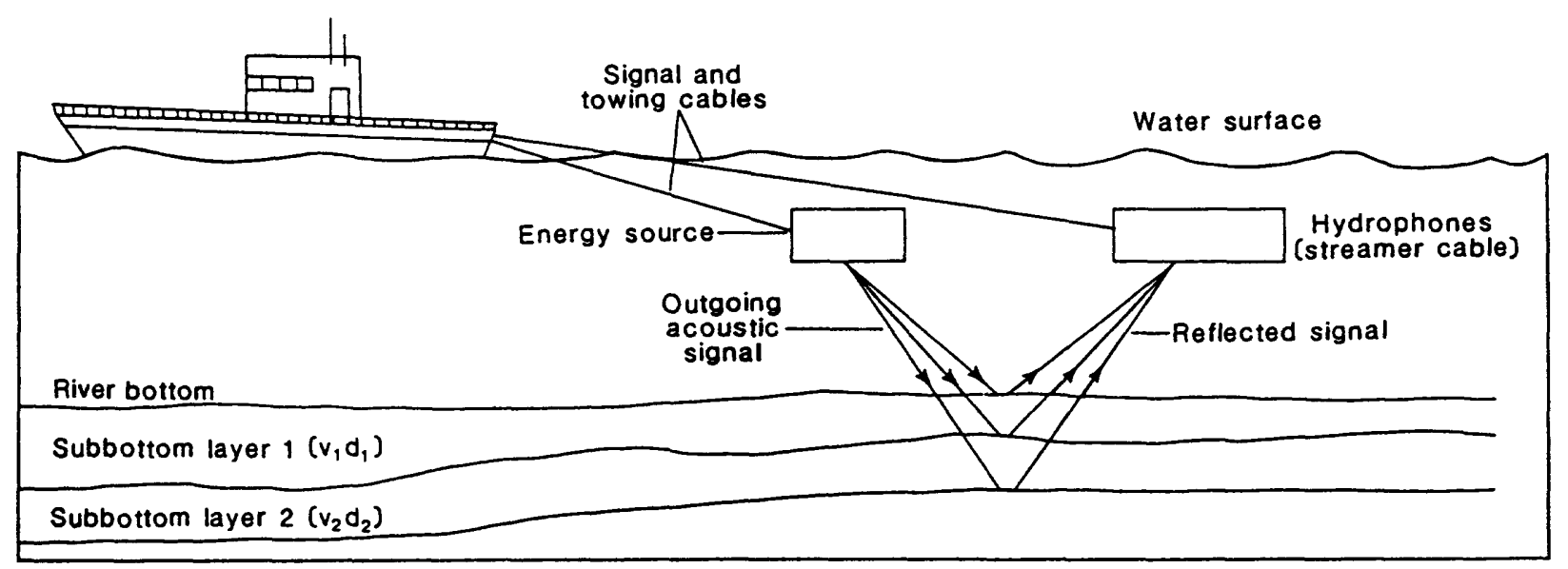

Figure 20. Generalized configuration of equipment and ray paths from acoustic source to hydrophones for single-channel marine seismic-reflection profiling. 
Table 9. Reflection coefficients (R) of typical geologic boundaries (from Sylwester, 1983)

\begin{tabular}{|c|c|}
\hline Geologic boundary & $\mathbf{R}$ \\
\hline Water-sand & $0.3-0.4$ \\
\hline Water-limestone & .5 \\
\hline Water-clay/silt & $.1-.2$ \\
\hline Water-mud & $.05-.1$ \\
\hline Water-air & -1 \\
\hline Mud-clay/silt & .1 \\
\hline Clay-sand & .1 \\
\hline Sand-limestone & .2 \\
\hline Clay-limestone & .3 \\
\hline Sand-granite & .4 \\
\hline
\end{tabular}

central channel is relatively flat and is covered by a fine-grained, organic-rich, dark grayish-black mud. In places, this mud can be several feet thick.

At the mouths of Slocum and Hancock Creeks, inlet channels cut across the wave-cut bench, resulting in locally deep areas on the bench. Within the tidal reaches of Slocum and Hancock Creeks, water velocities are usually low and the channels are broad and shallow, averaging about $5 \mathrm{ft}$ deep. The beds of these streams are covered by a layer of organic-rich sediment containing abundant plant detritus, much of which is apparently derived from the dense vegetation along the shorelines.

Experience with seismic-reflection profiling in the nearby New River (Cardinell and others, 1990) has shown that the combination of shallow water and soft organic bottom sediment might reduce or impede penetration and(or) resolution of the acoustic signal. In order to determine which of two source-to-receiver configurations to use, test profiles were run with two different configurations. The first configuration had the geopulse sound source and the streamer cable (hydrophones) mounted in series and towed behind the boat. The sound source was attached to the towing cable ahead of the streamer cable. A float was attached to the end of the streamer cable to apply sufficient tension for the sound source and streamer cable to trail the boat in a straight line. In the second configuration, outriggers were attached to the bow of the boat, and the sound source was towed on one side of the boat and the streamer cable on the other side. This configuration resulted in the sound source being towed parallel with the midpoint of the hydrophone array.
These two configurations were each run at three power settings of 105,175 , and $280 \mathrm{~J}$ (joules). Trial results indicate that both configurations penetrated the river and stream bottoms, except where soft bottom sediments occurred. However, the trailing configuration with the highest power yielded the best results in the Neuse River, whereas the trailing configuration at $175 \mathrm{~J}$ had the best results in Slocum and Hancock Creeks, which appeared to have higher concentrations of suspended sediment than the river. Very little penetration was achieved with either configuration in either of the two creeks because of the abundance of soft bottom sediment. The best penetration was achieved over the wave-cut bench in the Neuse River. The system used for the survey is the Geopulse System manufactured by Ferranti Ocean Research Equipment.

The survey was conducted along a $6.5-\mathrm{mi}$ reach of the Neuse River, a 5-mi reach of Slocum Creek, and a 3.5-mile reach of Hancock Creek. The surveyed reach of the Neuse River extends from about $1 \mathrm{mi}$ upstream of the Air Station boundary and downstream to the Pine Cliff Recreation Area. The surveyed reach of Slocum Creek extends upstream from the mouth of the creek, as does the surveyed reach of Hancock Creek. The survey lines on all three bodies of water were, for the most part, run in the downstream direction. Some survey lines were run more than once in attempts to obtain the best quality data. The data were collected during the period December 6, 1994, to January 21, 1995. 
The surveys were conducted using a $25-\mathrm{ft}$, twin outboard, Privateer boat. A Global Positioning System (GPS) was carried onboard to provide accurate, realtime latitude and longitude data. The acoustic source was towed approximately $32 \mathrm{ft}$ behind the boat outside the wake. The streamer cable containing the hydrophone array was towed behind the acoustic source. The hydrophone array consisted of 12 elements connected in parallel and separated by $2 \mathrm{ft}$. Boat speeds were in the 2 to $5 \mathrm{mi} / \mathrm{h}$ (miles per hour) range while profiling.

The sweep rate (recording time between trigger pulses) was set at $200 \mathrm{~ms}$ and the repetition rate (firing rate) of the acoustic source at $400 \mathrm{~ms}$ at a power setting of $280 \mathrm{~J}$ for most of the survey. The time base for the recorder was set at 0.12 , which in combination with an estimated seismic velocity of $5,000 \mathrm{ft} / \mathrm{s}$ (feet per second) would profile the top $300 \mathrm{ft}$ beneath the water surface. Typically, a velocity of $5,000 \mathrm{ft} / \mathrm{s}$ is used for shallow-marine unconsolidated sediments (Cardinell and others, 1990).

Positioning during the survey was accomplished with a GPS, channel markers, and dead reckoning using topographic maps and the boat compass. Navigation fix marks were manually placed on the seismic records at frequent intervals of time, generally 10 to 12 minutes in the Neuse River, to give a spacing of about $0.5 \mathrm{mi}$ along the survey line.

It became apparent after the first day of profiling that the acoustic energy pulse was being seriously attenuated by the soft sediments in the channel of Slocum Creek. Attenuation of the seismic signal also occurred in a few sections of the Neuse River as a result of soft sediment deposits, particularly in the central channel. Consequently, the survey was redesigned to collect data along the south shore of the Neuse River so that the profile lines passed over the wave-cut bench where there is a minimum of soft sediment. In the creeks, experiments with cutting off one or both motors and allowing the boat to drift showed a noticeable improvement in penetration. This was attributed, in part, to the increase in signal to noise ratio. However, in the absence of an alternative (quieter) form of propulsion, profiles in the creeks follow the central channel paths favoring deep water areas in hopes that the hydrophones would pick up less engine noise and that data-enhancement procedures during playback of the recorder tapes would improve data quality along these profiles.

\section{Data Analysis}

Tape recordings of seismic data were played back through the preamplifier to the graphic recorder at various filter settings and gain levels in an attempt to enhance the printed record. Generally, the filter setting of the $300-$ to $1,500-\mathrm{Hz}$ range on the signal processor gave the best combination of resolution and penetration. However, processing to improve resolution and penetration was often at the expense of resolution in the shallow part of the profile. The top 30 to $60 \mathrm{ft}$ were often lost from the processed record. The original field seismic-reflection record typically turned out to be the most informative for the interval of interest, that is the interval between the river bottom and the top of the Castle Hayne Limestone. Moreover, very little improvement of the record was achieved by processing in the areas where soft sediment caused signal attenuation.

The seismic-reflection records represent acoustic cross sections of the underlying sediments of the Neuse River estuary. The vertical axes are initially scaled in units of time (milliseconds) and represent the two-way travel time from the source to a reflector and back to the hydrophone array. Given an acoustic velocity for the sedimentary section, the vertical axes can be rescaled in units of depth. The horizontal axes represent the distance covered by the seismic survey in a given amount of time. Slopes of river-bottom reflectors and internal structures are exaggerated due to vertical-scale exaggeration.

One of the more difficult tasks in interpreting continuous seismic-profile data is obtaining good depth estimates to correlate with available borehole lithologic and geophysical data. Depth estimates can be obtained from either correlating the seismic wavelet character of the reflection records with available borehole (lithologic and geophysical) data or from actual determinations of acoustic velocity in sediment. Usually a combination of both methods is used to estimate depth.

An average velocity was calculated for the interval of interest using acoustic velocity data from the three VSP profiles determined in stratigraphic test wells 1-3. Acoustic velocities were determined for 5$\mathrm{ft}$ intervals of the sedimentary section in each of the test wells and are presented in table 6. The interval of interest in the marine seismic section lies between the bottom of the river and $100 \mathrm{ft}$ below sea level. This interval corresponds to the interval between $30 \mathrm{ft}$ and 
$125 \mathrm{ft}$ below land surface for a typical well at the Air Station, and encompasses both the Yorktown and Pungo River confining units. The average acoustic velocity for this interval was first calculated for each well assuming an average 5-ft depth of water at the top of the interval, and a seismic velocity of water of 4,800 $\mathrm{ft} / \mathrm{s}$. The average velocities between sea level and 100 ft below sea level for test wells 1, 2, and 3 are 5,897, 5,430 , and $5,690 \mathrm{ft} / \mathrm{s}$, respectively. The average for the three test wells is $5,673 \mathrm{ft} / \mathrm{s}$. This value is in good agreement with values in the range of 5,000 to 6,000

$\mathrm{ft} / \mathrm{s}$ for unconsolidated to semiconsolidated sediments reported in other studies (McKinney, 1985; Cardinell and others, 1990). The resultant average velocity value was used to convert two-way travel times to estimates of depth. When these depths are placed on the marine seismic profiles and the depths of major continuous reflectors are compared to lithologic and geophysical logs from wells on the Air Station, there is general agreement between geologic units and reflecting surfaces in the marine seismic profiles.

\section{Results}

Three seismic profiles were run along the south shore of the Neuse River from a point west of the Air Station boundary to a point near Pine Cliff Recreation Area (fig. 21). Segments of these profiles having the best resolution and depth penetration were combined to create the composite seismic profile A-S shown in figure 22 (at the back of report). A strong reflector with an apparent eastward dip occurs at a depth of about 34 $\mathrm{ft}$ near the west end of the profile and at a depth of about $58 \mathrm{ft}$ at the east end of the profile. This strong reflector is paralleled at slightly greater depth by 2 or 3 additional reflectors which may represent layering within a unit with a total thickness of 10 to $15 \mathrm{ft}$. This unit may represent the Yorktown confining unit typically identified in wells at depths between 55 and $65 \mathrm{ft}$ below land surface. Other continuous reflectors occur at depths of about $75 \mathrm{ft}$ and $100 \mathrm{ft}$ below sea level. These may represent the upper and lower boundaries of the Pungo River confining unit.

Besides laterally extensive reflectors, the seismic sections also show evidence of cut-and-fill structures (paleochannels) as well as cross bedding. Between the river bottom and the first strong reflector, the section lacks well-defined layering, although for the most part it appears to be flat lying. Below the unit thought to represent the Yorktown confining unit, reflectors indicate complex stratigraphy with large cutand-fill structures cutting across bedding. Cross bedding also appears to be present in some parts of the section. Most of the complex structure appears to occur in the interval between $50 \mathrm{ft}$ and $90 \mathrm{ft}$ below sea level, but some structural complexity also is observed at depths greater than $100 \mathrm{ft}$ below sea level and may be within the Pungo River Formation.

The largest of the paleochannels identified along section A-S occurs immediately north of the Air Station between latitude $34^{\circ} 57^{\prime} 00^{\prime \prime} \mathrm{N}$, longitude $76^{\circ}$ $53^{\prime} 17^{\prime \prime} \mathrm{W}$ and latitude $34^{\circ} 56^{\prime} 42^{\prime \prime} \mathrm{N}$, longitude $76^{\circ} 51^{\prime}$ $33^{\prime \prime} \mathrm{W}$. The width of the structure is approximately 1.2 mi along the line of section, but actually may not be this wide unless the line of section is normal to the strike of the structure. This structure is not a single paleochannel, but is actually interpreted to be two paleochannels with the westernmost paleochannel being the older of the two, and the easternmost, and youngest paleochannel partially incised into the older paleochannel. The deepest part of the structure is in the western paleochannel and appears to reach a maximum depth of 85 to $90 \mathrm{ft}$ below sea level. Based on lithologic data from wells, this paleochannel may be incised into the Pungo River confining unit.

The acoustic velocity profiles suggest that the sediment infilling the paleochannels lacks the distinctive layering discernible outside the paleochannels. This may be due to a lack of acoustic contrast, as between sand and clay layers. It also may indicate that the channel fill is relatively homogeneous with respect to the lithology of fill material. If such channels are filled with permeable sediments and if these or similar channels are present beneath land areas of the Air Station, they also may serve as conduits for ground-water flow, movement of contaminants, or flow of saltwater from the Neuse River estuary.

Although much information was obtained using seismic-reflection profiling techniques, there are limits to the use of these data. Making accurate depth determinations of key hydrogeologic units on the seismic record depends on the accuracy of acoustic velocity data, borehole geophysical well-log data, and available lithologic and paleontological information. It is not possible to identify lithology and facies changes from the reflection record alone; nor will seismicreflection records supply qualitative information on hydraulic parameters, such as porosity and permeability of key units. In order to determine hydrologic information, and to confirm what the reflection records suggest the hydrogeologic setting to be, physical data must be obtained from water-supply wells, borings, and test wells. 


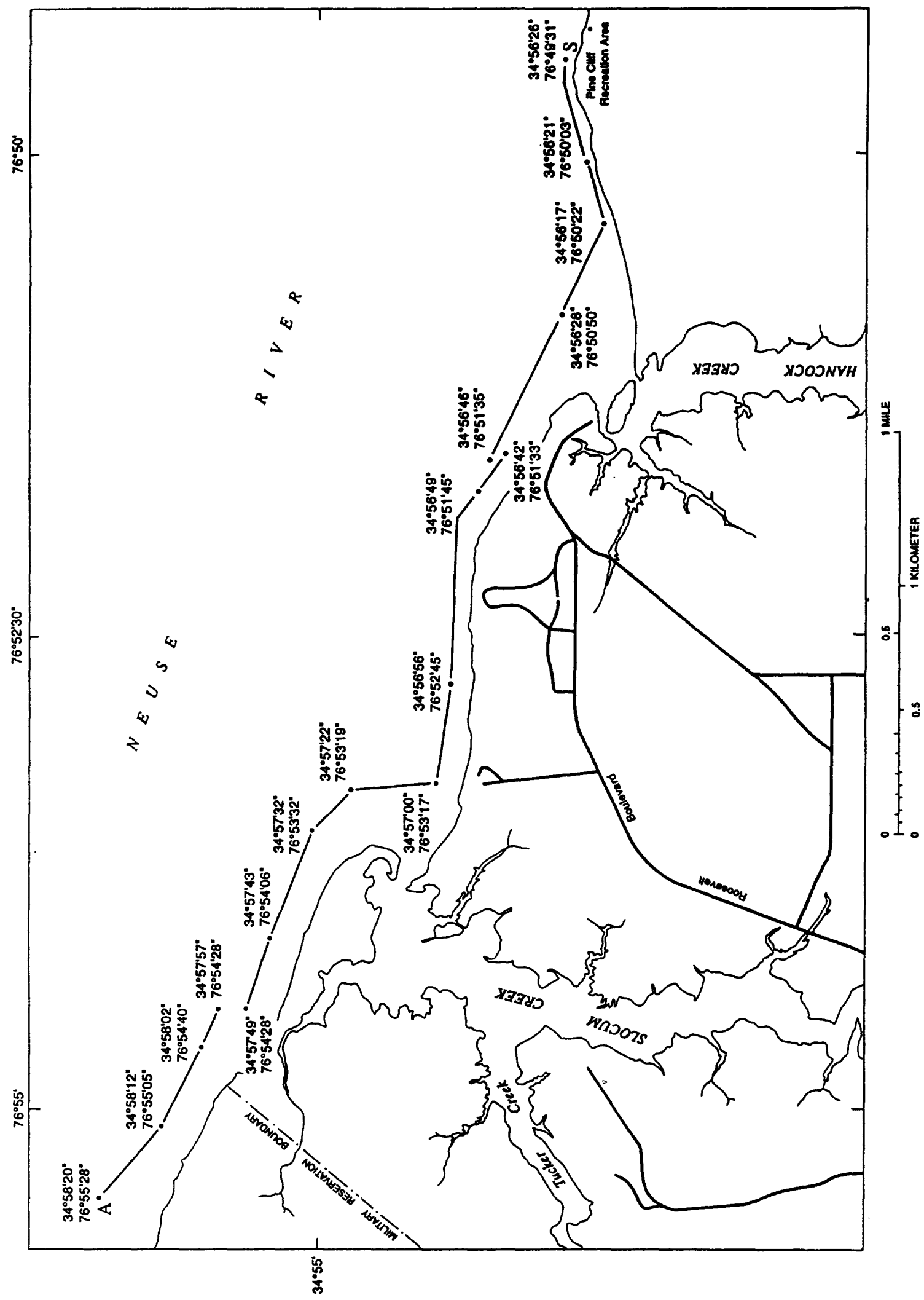

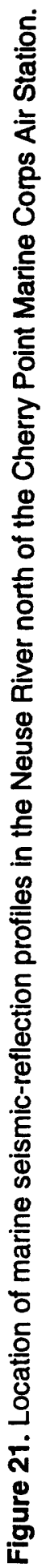




\section{DELINEATION OF PALEOCHANNELS}

A combination of techniques, including land and marine seismic-reflection surveys, test drilling, collection of lithologic samples, and borehole geophysical logging were used to identify geologic structures, including paleochannels, and evaluate the continuity of stratigraphic units beneath the Air Station. The use of seismic-reflection techniques provided information about subsurface structures that previously could only be speculated about on the basis of well records. Seismic-reflection techniques provide continuous profiles that are needed to link point data observed at wells, and well records provide the vertical stratigraphic record needed to interpret seismic profiles. Wells also allow access to the subsurface for the collection of VSP data that are needed to determine the depth to reflectors. In combination, these techniques helped to identify paleochannels and other structures at several locations beneath the Air Station.

Locations of paleochannels and related structures identified during this study are summarized in figure 23. The techniques used to delineate these structures are described in preceding sections, as well as the types of features identified by the different methods, or combination of methods, employed at different locations on the Air Station. The structures that were identified are described in more detail below. Their possible influence on the hydrogeology of the Air Station also is discussed.

A pair of superimposed paleochannels with a total apparent width of approximately $1.2 \mathrm{mi}$ was identified beneath the south shore of the Neuse River by marine seismic-reflection profiling (fig. 24). The paleochannels were found about $800 \mathrm{ft}$ offshore and lie between the mouths of Slocum and Hancock Creeks (fig. 23). The older and deeper channel is on the west end of the profile; the younger channel is on the east end of the profile and is superimposed on the older paleochannel (fig. 24). Based on the seismic profile, the two channels are apparently capped by a relatively flat-Iying unit about 10 to $15 \mathrm{ft}$ thick that dips slightly to the east. About $30 \mathrm{ft}$ of younger sediment occurs between the top of this unit and the river bottom. The younger sediment shows little apparent structure. Above the deepest point in the western paleochannel, the contact between the overlying unit and the channel fill occurs at approximately $53 \mathrm{ft}$ below sea level. The bottom of the channel is at approximately $87 \mathrm{ft}$ below sea level, although faint reflectors suggest that there may be even deeper cut-and-fill structures that extend more than $100 \mathrm{ft}$ below sea level. The thickest discernible fill in the channel is about $34 \mathrm{ft}$ thick. When compared to lithologic data from wells, particularly those along Access Road, the unit that caps the paleochannel is probably equivalent to the Yorktown confining unit (the James City Formation of Pleistocene age). The paleochannel appears to be incised through the Yorktown aquifer and more than half way through the Pungo River confining unit which serves as the Castle Hayne aquifer confining unit in the vicinity of the Air Station. The Pungo River confining unit typically occurs in the interval between 80 and 120 $\mathrm{ft}$ below land surface, or about 55 to $95 \mathrm{ft}$ below sea level (assuming an average land surface elevation of about $25 \mathrm{ft}$ ). With the deepest point of the paleochannel at $87 \mathrm{ft}$ below sea level, only an estimated $8 \mathrm{ft}$ of the Pungo River confining unit remains beneath this part of the paleochannel.

The influence of the paleochannel described above on the hydrology of the ground-water flow system beneath the Air Station will depend on (1) the magnitude and direction of hydraulic gradients in the vicinity of the paleochannel, (2) the nature of the sediment filling the paleochannel, (3) whether the paleochannel extends beneath the Air Station, (4) whether the paleochannel cuts through the Pungo River confining unit at some point along its course, and (5) whether or not the Yorktown confining unit is breached above this paleochannel. Beneath the south shore of the river, the Yorktown confining unit is apparently intact, but it may be breached by younger paleochannels elsewhere.

All of the major confining units above the Castle Hayne aquifer are breached by a large paleochannel that trends in a northwest to southeast direction across the southwest corner of the Air Station and includes the Facilities Maintenance area (fig. 23). Only a thin, (approximately 5 to $6 \mathrm{ft}$ thick) green silty clay that occurs in the interval between 50 and $60 \mathrm{ft}$ below land surface can be correlated between wells in the area. Additional thin clays have been encountered in test wells, but there is no apparent correlation between wells; therefore, these clays are not considered laterally extensive. Three test wells have been drilled in the area of this paleochannel; one is described by Murray and Keoughan (1990, table 8, site 3 ), and its location is shown as well number 18 in figure 8 . Two of the wells, Strat- 1 and Strat-3, were drilled during this study and also are shown in figure 8 . The lithologic logs (tables 2 and 4) and natural gamma-ray logs (figs. 9-A and 


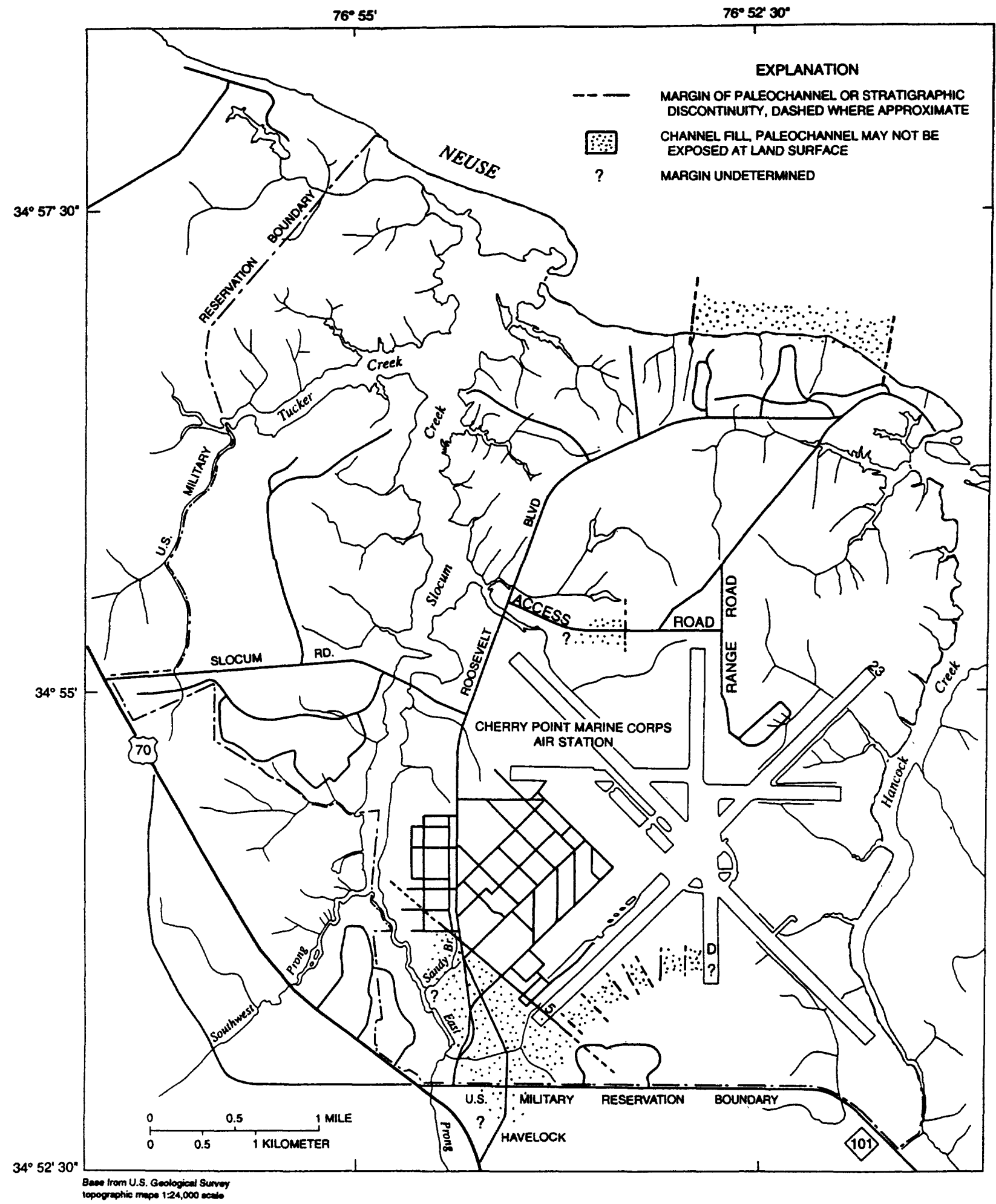

Figure 23. Locations of suspected paleochannels beneath Cherry Point Marine Corps Air Station. 

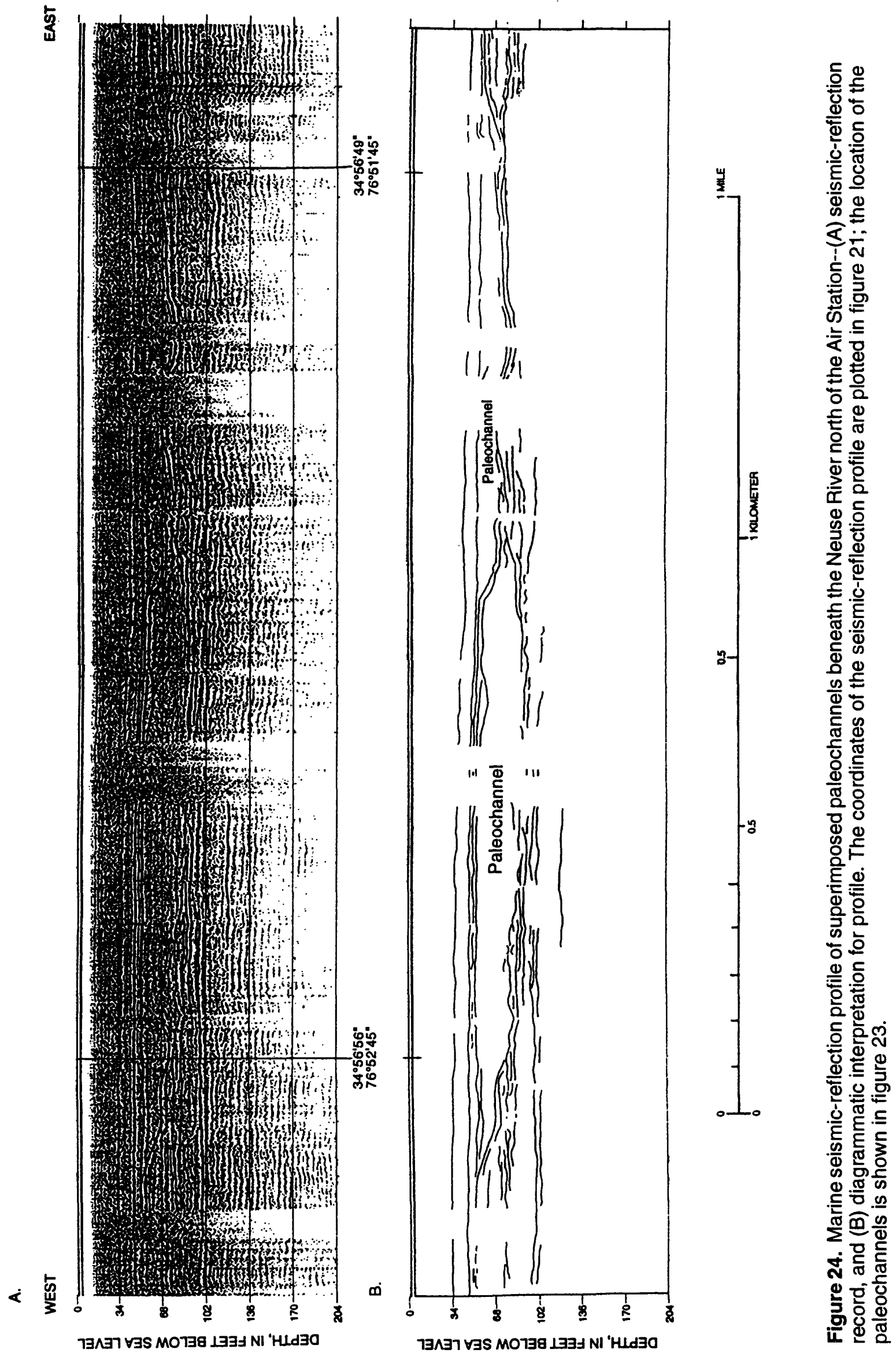
11-A) for these wells are similar in that much of the section penetrated by these wells is sandy with occasional shell horizons and thin clay lenses. A natural gamma-ray log run in water supply well 17 (no. 19, fig. 8) has a signature similar to the logs from wells 18 (fig. 8), Strat-1, and Strat-3. Both Strat-1 and Strat-3 are sufficiently deep to penetrate the top of a sandy shell horizon beginning at about 155 to $160 \mathrm{ft}$ below land surface. Well Strat-1 is $163 \mathrm{ft}$ deep; Strat-3 is $204 \mathrm{ft}$ deep and encountered limestone in the River Bend Formation at about $185 \mathrm{ft}$ below land surface.

Land seismic-reflection lines A-7 and B-2 (fig. 8) image the northeast flank of this large paleochannel. The seismic-reflection profile of line A-7 and the interpretation of this profile are shown in figure 25. A hydrogeologic section from water-supply well 14 to stratigraphic test well 3 is shown in figure 26; the position of seismic-reflection line A-7 relative to this profile and the flank of the paleochannel also is shown. Line B-2 extends out into the paleochannel (fig. 27) but there is no indication of a southwest margin.

Reflectors on the seismic profile in line B-2 also suggest that the paleochannel reaches the top of the limestone of the River Bend Formation. Based on well data from the wells described above and the seismic profiles in lines B-2 and A-6 (fig. 8), which is south of the Cunningham Boulevard gate, the southwest margin of the paleochannel is outside the Air Station boundary. Because a sandy shell horizon was encountered in both Strat -1 and Strat-3 at about 155 to $160 \mathrm{ft}$, and because of similarities to the lower Pungo River lithologies encountered in other wells outside of this paleochannel, it is not obvious that the paleochannel reached the top of the limestone in the River Bend Formation. It may only have incised its channel part way through the Pungo River Formation.

Hydrologically, it makes little difference whether the paleochannel reaches the limestone because the lower Pungo River lithologies appear to be as permeable as the channel fill above.

The presence of this large paleochannel has been postulated in previous studies (Lloyd and Daniel, 1988; Murray and Keoughan, 1990) on the basis of limited well data. It also has been postulated that the lack of confining units in the area of the paleochannel has contributed to contamination of ground water in the Castle Hayne aquifer beneath this paleochannel. Ground water containing benzene and other priority pollutant organic compounds (U.S. Environmental Protection Agency, 1979a; 1979b) was found in wells now known to be within or adjacent to this paleochannel; water from water-supply well 17 (number 19, fig. 8) contained four priority pollutant organic compounds, including benzene (Lloyd and Daniel, 1988). Subsequent to identification of contamination in this area, supply wells 16 (number 15 , fig. 8) and 17 were removed from service.

Several cut-and-fill structures were imaged along seismic-reflection line B-2 northeast of the large paleochannel described above. These are indicated on the hydrogeologic section in figure 27. These structures are apparently incised into the Yorktown aquifer, much like the pair of paleochannels found beneath the Neuse River to the north. The Pungo River confining unit is apparently completely breached by two paleochannels, and nearly breached by three other paleochannels. One of the paleochannels appears to be incised to or slightly into the top of the River Bend Formation.

If these paleochannels continue to the west or northwest similar to the large paleochannel beneath the southwestern part of the Air Station, they may provide an explanation for the missing Pungo River confining unit identified in wells drilled by NUS Corporation in the vicinity of the Naval Aviation Depot (NADEP). Three of these wells are between 110 and $120 \mathrm{ft}$ deep (numbers 16, 20, and 21; fig. 8). The upper confining unit (Yorktown confining unit) is somewhat thinner in the NADEP area than observed in wells to the north and northwest. This may represent a general stratigraphic thinning from north to south as suggested by Lloyd and Daniel (1988), or it may be associated with erosion along the margin of the large paleochannel immediately to the southwest. However, based on natural gamma-ray logs, single-point resistivity logs, and spontaneous-potential logs there is little or no clay between 80 and $122 \mathrm{ft}$ in these three wells. This suggests that the Pungo River confining unit has been breached in this area by erosion and it is most likely that the erosion was associated with a paleochannel, but not the same paleochannel found immediately to the southwest. Whether the missing confining units in the NUS Corporation wells are associated with paleochannels identified along seismic-reflection line B-2 is unknown, but the missing confining units appear to be related to the same erosional cycle and, thus, are contemporaneous. 

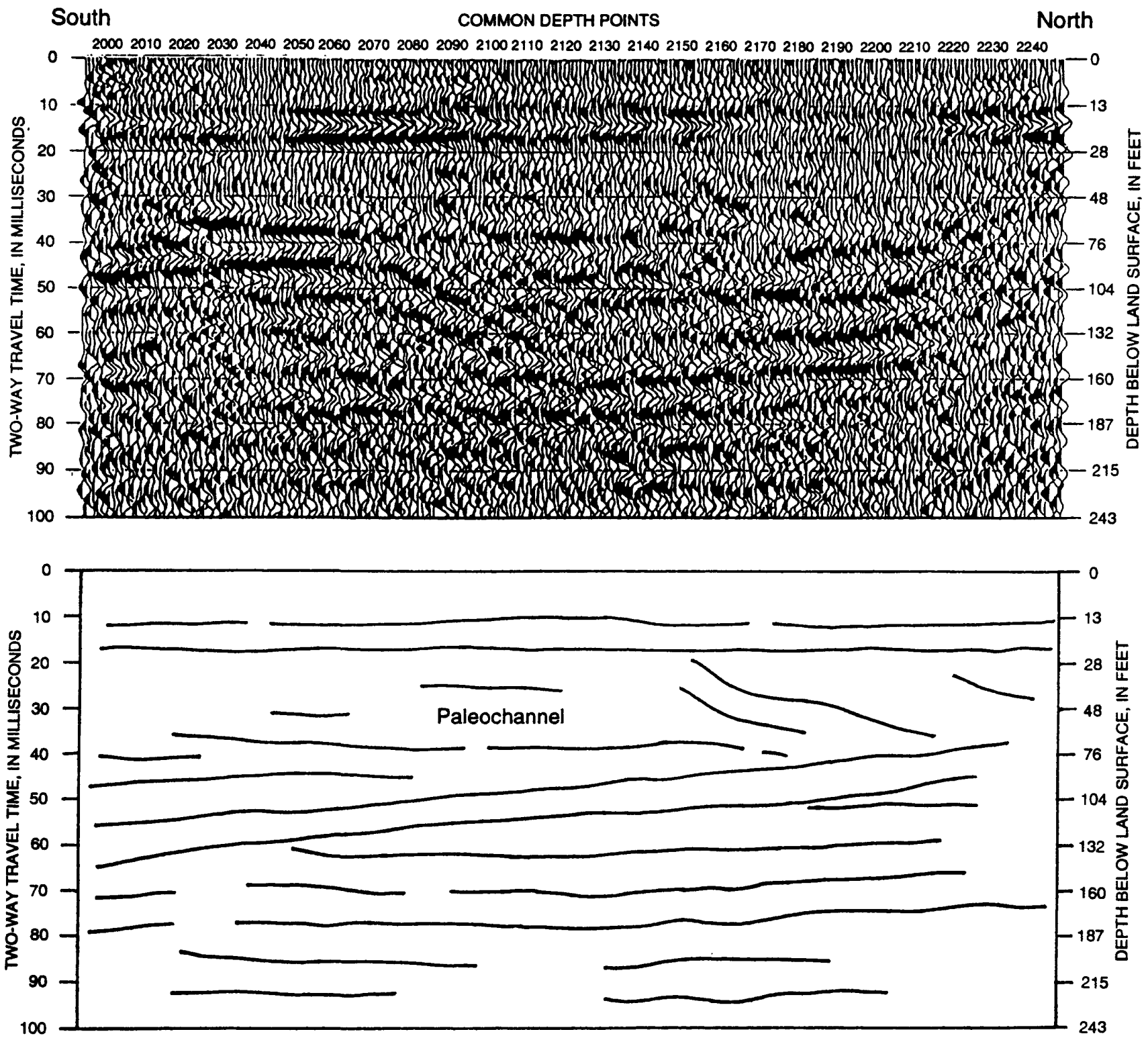

Figure 25. Land seismic-reflection profile A-7--(A) seismic-reflection record, and (B) diagrammatic interpretation for profile. 

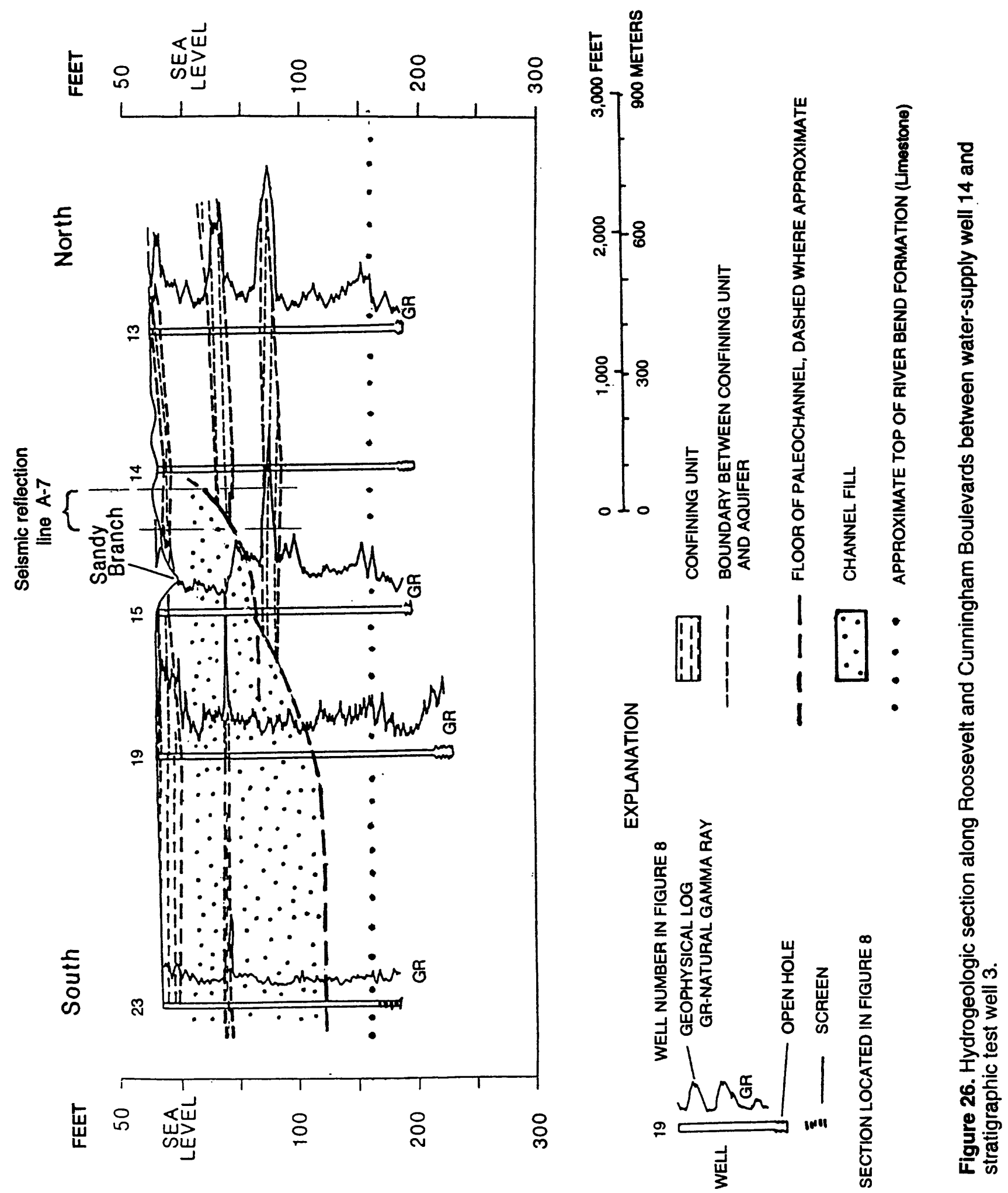


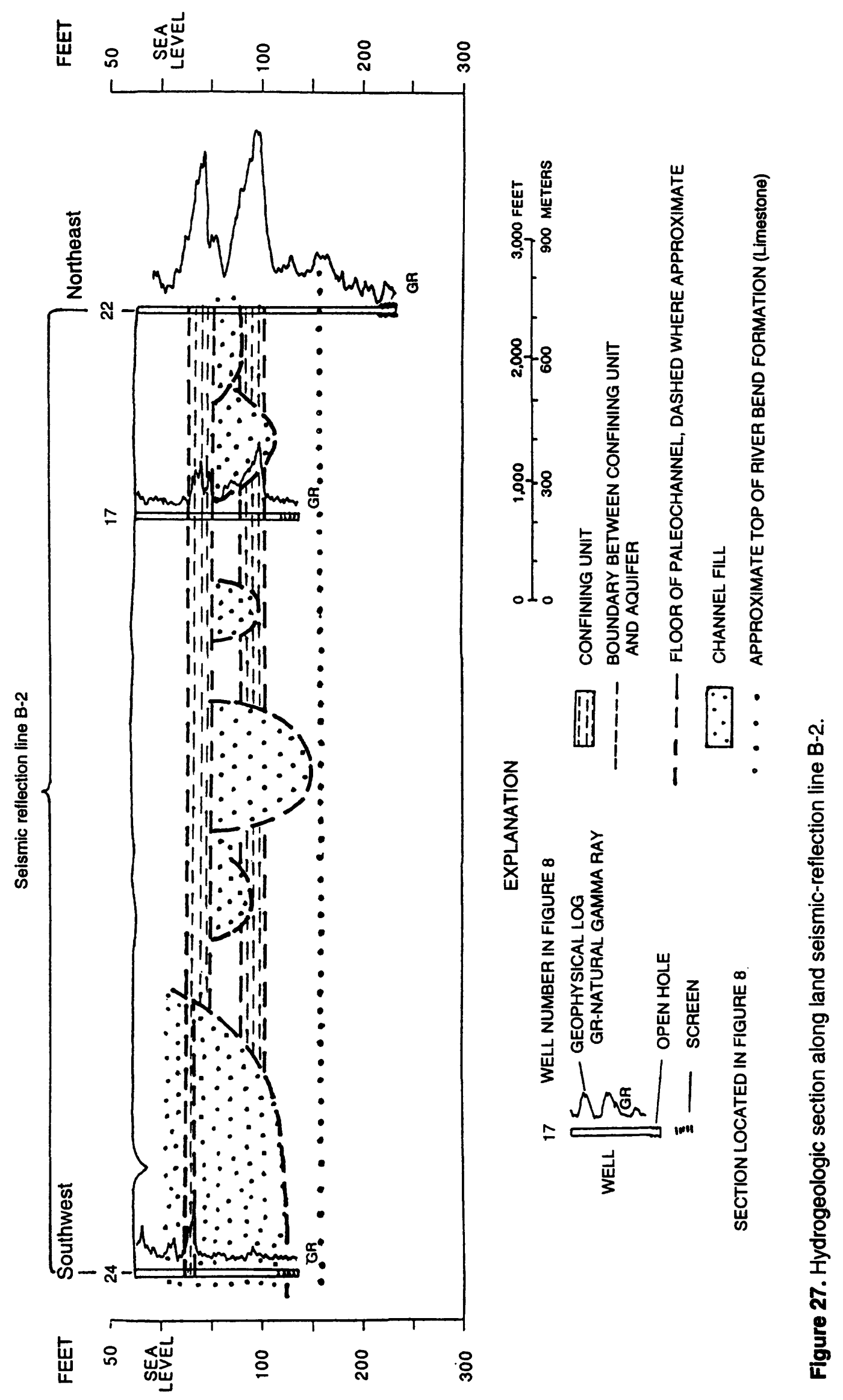


The role of these paleochannels on hydrogeologic conditions beneath the Air Station will depend, with minor modification, on the same five conditions previously mentioned with regard to the large paleochannels found beneath the Neuse River. That is, vertical connection between the aquifers will depend on (1) the magnitude and direction of hydraulic gradients in the vicinity of the paleochannels (2) the nature of the sediment filling the paleochannels, (3) the extent of the paleochannels beneath the Air Station, (4) whether the smaller paleochannels also cut through the Pungo River confining unit at some point along their courses, and (5) whether the Yorktown confining unit is breached above any of these paleochannels.

Along the composite hydrogeologic section defined by seismic-reflection lines B-1 and B-3 (fig. 28), no evidence of paleochannels was found east of Range Road at least as far as runway 23 . Westward dipping reflectors, probably indicative of cross bedding, occur in the Pungo River Formation just east of Range Road. The remainder of the section above the River Bend Formation is nearly flat lying and relatively uniform in thickness. The same conditions apparently exist west of Range Road along seismic line B-3 for about $2,950 \mathrm{ft}$. At this point a structural break occurs in the section with reflectors apparently lower on the west side of the break than on the east side. Whether this break is associated with a paleochannel cannot be determined with certainty from data currently available.

The paleochannels identified during this study are incised into and through various stratigraphic units and are capped by stratigraphic units of various ages. It is apparent that the paleochannels found beneath the Air Station are associated with different periods of erosion that occurred both during the Quaternary and Tertiary ages. Therefore, breeches of the confining units above the Castle Hayne aquifer (in addition to those identified to date) may be present but are not readily apparent or easily detectable.

\section{SUMMARY AND CONCLUSIONS}

The U.S. Marine Corps Air Station, Cherry Point, North Carolina, is located in southeastern Craven County in the Coastal Plain physiographic province. The Air Station is underlain by four freshwater-bearing aquifers that are composed primarily of sand and sandy limestone to a depth of about $500 \mathrm{ft}$ below land surface. The sediments are saturated with saline water below this depth. The four aquifers are the surficial, Yorktown, and upper and lower Castle Hayne. The upper and lower Castle Hayne aquifers serve as the principal supply of freshwater for the Air Station. The upper Castle Hayne aquifer is composed of the sands and sandy shell beds of the Pungo River Formation and the limestone of the River Bend Formation. In other areas of the Coastal Plain, the lower part of the Pungo River Formation is a confining unit on top of the River Bend Formation and separates the Pungo River aquifer from the upper Castle Hayne aquifer, which is then restricted to the limestone of the River Bend Formation. Beneath the Air Station, the lower part of the Pungo River Formation, which typically occurs in the interval between 155 and $180 \mathrm{ft}$ below land surface, consists of shells, shell fragments, and sand. Thus, there is little or no hydrologic separation between the Pungo River Formation and the River Bend Formation. The lower Castle Hayne aquifer is composed of limestones, sandy limestones, and sands of the Castle Hayne Limestone. The aquifers are separated by clay confining units except where these units are thin or discontinuous.

Ground-water contamination has been found in the southern part of the Air Station where pumping from supply wells has created a potential for downward movement of contaminated ground water from the surficial and Yorktown aquifers into the Castle Hayne aquifer. The potential for movement of water from the surficial aquifer downward to the water-supply aquifer is greatest in areas where clay confining units are missing. Missing confining units could indicate the presence of a paleochannel. Paleochannels have been identified in the Quaternary and Tertiary sediments beneath the floor of Onslow Bay (Hine and Riggs, 1986). Some of these channels trend in a north-south direction and suggest similar channels may be present beneath the Air Station. If paleochannels filled with permeable material exist beneath the Air Station, these features could act as conduits for ground-water flow or movement of contaminants between the surficial and Castle Hayne aquifer.

Continuous single-channel marine seismicreflection profiling of the Neuse River north of the Air Station and Slocum and Hancock Creeks on the west and east sides of the Air Station, respectively, was conducted to collect data for use in describing the structural and depositional setting of hydrogeologic units overlying the upper Castle Hayne aquifer. Soft, gassy, bottom sediment prevented collection of usable data in the creeks, although attempts were made to collect data along $8.5 \mathrm{mi}$ of creek channel. Approximately $6.5 \mathrm{mi}$ of quality seismic data were collected in the Neuse River. A paleochannel structure 


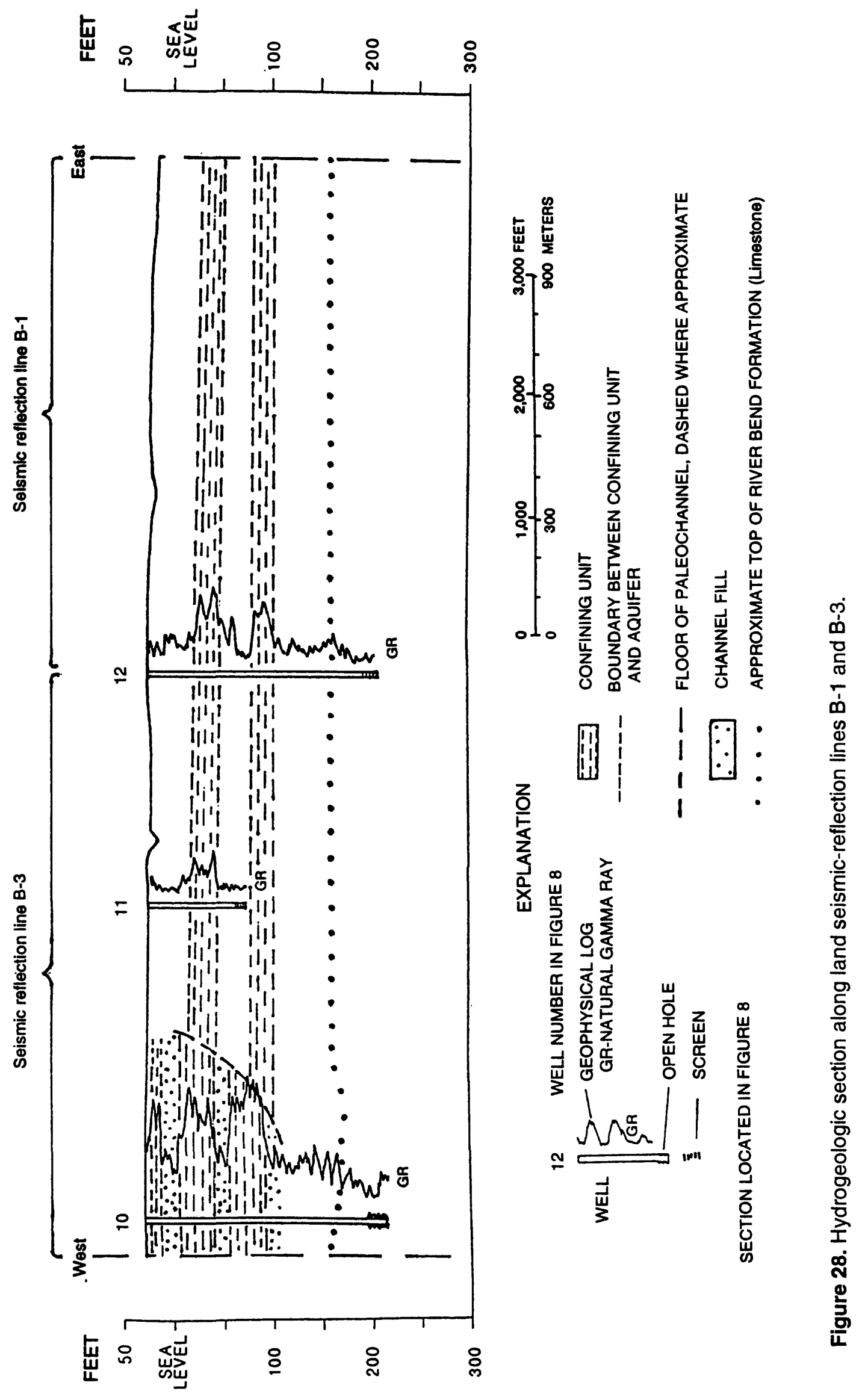


(consisting of two partially overlapping paleochannels) nearly $1.2 \mathrm{mi}$ wide and extending nearly $90 \mathrm{ft}$ and perhaps more than $100 \mathrm{ft}$ below sea level was found immediately north of the Air Station. Based on lithologic logs from wells located at the Air Station, this paleochannel structure appears to be incised within the Yorktown Formation and partially incised into the Pungo River confining unit (also the upper Castle Hayne aquifer confining unit in this area). This structure is thought to continue south or southeast beneath the Air Station.

Shallow, high-resolution land seismic-reflection techniques were used at the Air Station to delineate structures and correlate stratigraphy between the limestone of the River Bend Formation (about $180 \mathrm{ft}$ below land surface) and the Yorktown confining unit (about $35 \mathrm{ft}$ below land surface). Three different methods were used to acoustically image and correlate the subsurface geology to existing geologic, hydrogeologic, and geophysical data. The first method employed a series of thirteen 240-ft long 24-fold, CDP (common-depth point) lines to optimize acquisition parameters and equipment selection and to acquire essential information about the acoustic properties of the upper $250 \mathrm{ft}$ of sediment, both inside and outside the projected trace of a paleochannel. Guided by the 13 CDP lines, four stratigraphic test wells were drilled to acquire lithologic and borehole geophysical data. Walkaway VSP's (vertical seismic profiles) were acquired in three of the wells. Interval velocity data were acquired at 5-ft intervals using a holelock geophone and a hydrophone to measure acoustic velocity in the unsaturated and saturated sections, respectively, of each well. Acoustic velocity profiles were determined from the interval velocity data. Finally, three 12-fold CDP seismic-reflection profiles with line lengths of 7,100 linear $\mathrm{ft}, 4,800$ linear $\mathrm{ft}$, and 4,760 linear $\mathrm{ft}$ were designed and run to target channel features inferred from both drilling and the singlechannel marine seismic-reflection survey. The 4,800$\mathrm{ft}$ line was run along Access Road from near the EAD office east to Range Road and the 4,760-ft line was run from Range Road east along a gravel road to the end of runway 23 . The $7,100-\mathrm{ft}$ line was run from near the south end of taxiway D (Delta taxiway) southwest along a gravel road to a point near the Cunningham Boulevard gate. The land seismic-reflection techniques provided images of alternating sand and clay sequences with average thicknesses on the order of 20 to $30 \mathrm{ft}$. The land seismic data have a dominant frequency of about $200 \mathrm{~Hz}$, providing a minimum vertical bed resolution of about $6 \mathrm{ft}$.
An extremely complex series of erosional and depositional features can be interpreted on the CDP seismic-reflection profiles. The northeastern margin of a large paleochannel that underlies the southern part of the Air Station was identified on two CDP profiles. This feature strikes northwest to southeast and, based on data from test wells, cuts through both the Yorktown and upper Castle Hayne aquifer confining units. Paleochannels and suspected stratigraphic breaks were identified at other locations, including beneath Access Road, Slocum Road, and the gravel road from Cunningham Boulevard to the south end of taxiway D. Except for the large paleochannel at the south end of the Air Base, the other paleochannels along the profile from Cunningham Boulevard to the south end of taxiway D lie below the Yorktown confining unit, but may be incised into and perhaps through the Pungo River confining unit (upper Castle Hayne aquifer confining unit beneath the Air Station). No large paleochannel structures were identified along the profile from Range Road to runway 23, although dipping reflectors thought to represent westwarddipping cross bedding were noted in the Pungo River Formation. A major break in stratigraphic sections was identified on the profile along Access Road, but a geologic explanation for this break is uncertain. Analysis of borehole geophysical logs of wells along this profile suggest the break is an erosional feature and not a fault.

Shallow seismic-reflection techniques were successful in delineating stratigraphic units and bedding geometries important to the definition of the hydrogeologic framework of unconsolidated sediments less than $180 \mathrm{ft}$ deep at the Air Station. Paleochannels of Quaternary and Tertiary age were found at several locations that are apparently associated with different periods of erosion. Therefore, breeches of the confining units above the Castle Hayne aquifer (in addition to those identified to date) may be present but are not readily apparent or easily detectable. Marine seismic reflection was effective in delineating a pair of superimposed paleochannels. Land seismic reflection proved an effective tool for the horizontal extrapolation of geologic features from well to well and identification of additional paleochannels. Incorporation of land CDP seismic-reflection data with VSP data, marine seismic-reflection data, borehole geophysical logs, and lithologic logs from test wells greatly enhances both the confidence in and the overall understanding of the geology and hydrogeology of the area. 


\section{REFERENCES}

Balch, A.H., and Lee, M.W., 1984, Vertical seismic profiling: technique, applications and case histories: International Human Resources Development Corporation.

Birkelo, B.A.,Steeples, D.W., Miller, R.D., and Sophocleous, M.A., 1987, Seismic-reflection study of a shallow aquifer during a pumping test: Ground Water, v. 25 , Nov.-Dec. 1987 , p. $703-709$.

Brown, P.M., Miller, J.A., and Swain, F.M., 1972, Structural and stratigraphic framework, and spacial distribution of permeability of the Atlantic Coastal Plain, North Carolina to New York: U.S. Geological Survey Professional Paper 796, 79 p.

Cardinell, A.P., Harned, D.A., and Berg, S.A., 1990, Continuous seismic-reflection profiling of hydrogeologic features beneath New River, Camp Lejeune, North Carolina: U.S. Geological Survey Water Resources Investigations Report 89-4195, 33 p.

Daniel, C.C., III, 1981, Hydrology, geology, and soils of pocosins: A comparison of natural and altered systems, in Richardson, C.J., ed., Pocosin wetlands: An integrated analysis of Coastal Plain freshwater bogs in North Carolina: Stroudsburg, Pa., Hutchinson and Ross, Inc., p. 69-108.

Daniels, D.L., and Leo, G.W., 1985, Geologic interpretation of basement rocks of the Atlantic Coastal Plain: U.S. Geological Survey Open-File Report 85-655, 43 p., 4 plates.

Dobrin, M.B., 1976, Introduction to geophysical prospecting, 3d ed.: New York, McGraw Hill, 630 p.

Dubar, J.R., and Solliday, J.R., 1963, Stratigraphy of the Neogene deposits, lower Neuse Estuary, North Carolina: Southeastern Geology, v. 4, no. 2, p. 2134-2233.

Eimers, J.L., Daniel, C.C., III, and Coble, R.W., 1994, Hydrogeology and simulation of ground-water flow at U.S. Marine Corps Air Station, Cherry Point, North Carolina, 1987-90: U.S. Geological Survey WaterResources Investigations Report 94-4186, 75 p.

Fenneman, N.M., 1938, Physiography of Eastern United States: New York, McGraw-Hill, 714 p.

Floyd, E.O., 1969, Ground-water resources of Craven County, North Carolina: U.S. Geological Survey Hydrologic Investigations Atlas HA-343, 2 sheets.
Floyd, E.O., and Long, A.T., 1970, Well records and other basic ground-water data, Craven County, North Carolina: North Carolina Department of Water and Air Resources, Ground-Water Circular No. 14, 111 p.

Gal'perin, E.I., 1974, Vertical seismic profiling: Tulsa, Okla., Society of Exploration Geophysics Special Publication 12.

Gary, Margaret, McAfee, Robert, Jr., and Wolf, C.L., editors, 1974, Glossary of geology: Falls Church, Va., American Geological Institute, 805 p.

Giese, G.L., Eimers, J.L., and Coble, R.W., 1991, Simulation of ground-water flow in the Coastal Plain aquifer system of North Carolina: U.S. Geological Survey Open-File Report 90-372, 178 p.

Goforth, T., and Hayward, C., 1992, Seismic reflection investigations of a bedrock surface buried under alluvium: Geophysics, v. 57, p. 1217-1227.

Hardage, B.A., 1983, Vertical seismic profiling, part A-principles: Geophysical Press.

Heath, R.C., 1975, Hydrology of the Albemarle-Pamlico region, North Carolina, A preliminary report on the impacts of agricultural developments: U.S. Geological Survey Water Resources Investigations 9-75, 98 p.

1980, Basic ground-water hydrology with reference to conditions in North Carolina: U.S. Geological Survey Open-File Report 80-44, 86 p.

1983, Basic ground-water hydrology: U.S. Geological Survey Water-Supply Paper 2220, 84 p.

Hine, A.C., and Riggs, S.R., 1986, eds., Geologic framework, Cenozoic history, and modern processes of sedimentation on the North Carolina continental margin, in Textoris, D.A., ed., SEPM Field Guidebooks, southeastern United States third annual midyear meeting, 1986, Raleigh, N.C., p. 129-194.

Hine, A.C., and Snyder, S.W., 1985, Coastal lithosome preservation: Evidence from the shoreface and inner continental shelf off Bogue Banks, North Carolina: Marine Geology, v. 63, p. 307-330.

Jongerius, P., and Helbig, K., 1988, Onshore highresolution seismic profiling applied to sedimentology: Geophysics, v. 53, p. 1276-1283. 
Keoughan, K.M., 1988, Stratigraphy of the Pliocene and Pleistocene deposits of Cherry Point Marine Corps Air Station, North Carolina: Chapel Hill, University of North Carolina, M.S. thesis, 71 p.

Kimrey, J.O., 1964, The Pungo River Formation, a new name for middle Miocene phosphorites in Beaufort County, North Carolina: Southeastern Geology, v. 5., no. 4, p. 195-205.

1965, Description of the Pungo River Formation in Beaufort County, North Carolina: North Carolina Department of Conservation and Development, Division of Mineral Resources, Bulletin No. 79, 131 p.

LeGrand, H.E., 1960, Geology and ground-water resources of the Wilmington-New Bern area: Raleigh, North Carolina Department of Water Resources, Division of Ground Water, Ground-Water Bulletin 1, 80 p.

Lloyd, O.B., Jr., and Daniel, C.C., III, 1988, Hydrogeologic setting, water levels, and quality of water from supply wells at the U.S. Marine Corps Air Station, Cherry Point, North Carolina: U.S. Geological Survey WaterResources Investigations Report 88-4034, 76 p.

Mayne, W.H., 1962, Horizontal data stacking techniques: Supplement to Geophysics, v. 27, p. 927-938.

McKinney, R.B., 1985, Subsurface stratigraphy of late Jurassic through Middle Eocene strata in a portion of the North Carolina Coastal Plain: Raleigh, North Carolina State University, Raleigh, M.S. thesis, 88 p.

Miller, J.A., 1982, Stratigraphy, structure, and phosphate deposits of the Pungo River Formation of North Carolina: North Carolina Department of Natural Resources and Community Development, Division of Land Resources, Geological Survey Section, Bulletin 87, 32 p.

Miller, R.D., 1992, Normal moveout stretch mute on shallow-reflection data: Geophysics, v. 57, p. 1502-1507.

Miller, R.D., Pullan, S.E., Steeples, D.W., and, Hunter, J.A., 1994, Field comparison of shallow P-Wave seismic sources near Houston, Texas: Geophysics, v. 59 , p. $1713-1728$.

Miller, R.D., Pullan, S.E., Waldner, J.S., and Haeni, F.P., 1986, Field comparison of shallow seismic sources: Geophysics, v. 51, p. 2067-2092.

Miller, R.D., Steeples, D.W., and Brannan, M., 1989, Mapping a bedrock surface under dry alluvium with shallow seismic reflections: Geophysics, v. 54, p. 1528-1534.
Miller, R.D., Xia, Jianghia, Anderson, J.M., Laflen, D.R., 1995, High resolution seismic-reflection surveys at U.S. Marine Corps Air Station, Cherry Point, North Carolina: Lawrence, Kan., Kansas Geological Survey Open-File Report no. 95-29, in press.

Mixon, R.B., and Pilkey, O.H., 1976, Reconnaissance geology of the submerged and emerged Coastal Plain Province, Cape Lookout Area, North Carolina: U.S. Geological Survey Professional Paper 859, 45 p.

Murray, L.C., Jr., and Daniel, C.C., III, 1990 , Hydrogeologic and water-quality data from well clusters near the wastewater-treatment plant, U.S. Marine Corps Air Station, Cherry Point, North Carolina: U.S. Geological Survey Open-File Report 89-615, 56 p.

Murray, L.C., Jr., and Keoughan, K.M., 1990, Hydrogeologic, water-level, and water-quality data from monitoring wells at the U.S. Marine Corps Air Station, Cherry Point, North Carolina: U.S. Geological Survey Water Resources Investigations Report $89-4200,86$ p.

NUS Corporation, 1985, Confirmation study to determine existence and possible migration of specific chemicals in situ at the Marine Corps Air Station, Cherry Point, North Carolina, Round 1 sampling analytical results: Pittsburgh, Pa., Naval Facilities Engineering Command Contract N62470-84-B-6886, NUS Corporation Report (February 1985).

1986, Confirmation study to determine existence and possible migration of specific chemicals in situ at the Marine Corps Air Station, Cherry Point, North Carolina, Round 2 sampling analytical results: Pittsburgh, Pa., Naval Facilities Engineering Command Contract N62470-84-B-6886, NUS Corporation Report (February 1986).

1987, Report on hydrogeology, contaminants detected and corrective action/recommendations for the former surface impoundments [at the Marine Corps Air Station, Cherry Point, North Carolina] (Appendix 2-6): Pittsburgh, Pa., Naval Facilities Engineering Command Contract N62470-84-B-6886, NUS Corporation Report (January 1987).

Pullan, S.E., and Hunter, J.A., 1990, Delineation of buried bedrock valleys using the optimum offset shallow seismic-reflection technique, in Ward, S.H., ed., Society of Exploration Geophysics Investigations in Geophysics no. 5, v. 3, Geotechnical, p. 75-87.

Riggs, S.R., and O'Connor, M.P., 1974, Relict sediment deposits in a major transgressive coastal system: Sea Grant Publication UNC-SG-74-04, 37 p. 
Robinson, E.A., and Trietel, S., 1980, Geophysical signal analysis: Englewood Cliffs, N.J., Prentice-Hall, Inc., $466 \mathrm{p}$.

Schieck, D.G., and Pullan, S.E., 1995, Processing a shallow seismic CDP survey, in Proceedings on the Application of Geophysics to Engineering and Environmental Problems, April 23-26, Orlando, Florida: Environmental and Engineering Geophysical Society, 1995 Annual Meeting.

Sheriff, R.E., 1991, Encyclopedic dictionary of exploration geophysics, 3rd ed.: Tulsa, Okla., Society of Exploration Geophysicists, 376 p.

Sheriff, R.E., and Geldart, L.P., 1982, Exploration seismology--history, theory, and data acquisition: New York, Cambridge University Press, 243 p.

Somanas, C.D., Bennett, B.C., Park, C.B., and Chung, Y.J., 1992, Eavesdropper, version 2.51: Lawrence, Kansas Geological Survey.

Steeples, D.W., 1990, Early spectral shaping boosts data quality: Oil and Gas Journal, v. 88, no. 38, p. 49-55.

Steeples, D.W., and Miller, R.D., 1990, Seismic-reflection methods applied to engineering, environmental, and groundwater problems, in Ward, S.H., ed., Society of Exploration Geophysics Investigations in Geophysics no. 5, v. 1, Review and Tutorial, p. 1-30.

Stuckey, J.L., 1965, North Carolina--Its geology and mineral resources: Raleigh, North Carolina Department of Conservation and Development, $550 \mathrm{p}$.

Sylwester, R.E., 1983, Single-channel, high-resolution, seismic-reflection profiling: A review of the fundamentals and instrumentation, in Geyer, R.A., ed., Handbook of geophysical exploration at sea: Boca Raton, Fla., CRC Press, Inc., p. 77-121.

Telford, W.M., Geldart, L.P., Sheriff, R.E., Keys, D.A., 1976, Applied geophysics: New York, Cambridge University Press, 860 p.
U.S. Environmental Protection Agency, 1979a, Waterrelated environmental fate of 129 priority pollutants, v. I: U.S. Environmental Protection Agency publication 440/4-79-029a.

1979b, Water-related environmental fate of 129 priority pollutants, v. II: U.S. Environmental Protection Agency publication 440/4-79-029b.

1984, National secondary drinking water regulations, $37 \mathrm{p}$.

Ward, L.W., and Blackwelder, B.W., 1980, Stratigraphic revision of upper Miocene and lower Pliocene beds of the Chesapeake Group, Middle Atlantic Coastal Plain: U.S. Geological Survey Bulletin 1482-D, 61 p.

Ward, L.W.,.Lawrence, D.R., and Blackwelder, B.W., 1978, Stratigraphic revision of the middle Eocene, Oligocene, and lower Miocene - Atlantic Coastal Plain of North Carolina: U.S. Geological Survey Bulletin 1457-F, $23 \mathrm{p}$.

Waters, K.H., 1987, Reflection seismology--A tool for energy resource exploration, 3rd ed.: New York, John Wiley and Sons, $538 \mathrm{p}$.

Winner, M.D., Jr., and Coble, R.W., 1989, Hydrogeologic framework of the North Carolina Coastal Plain aquifer system: U.S. Geological Survey Open-File Report 87-690, 155 p.

Winner, M.D., Jr., and Simmons, C.E., 1977, Hydrology of Creeping Swamp watershed, North Carolina, with reference to potential effects of stream channelization: U.S. Geological Survey Water Resources Investigations $77-26,54 \mathrm{p}$.

Yilmaz, O., 1987, Seismic data processing, in Doherty, S.M., ed., Society of Exploration Geophysics Investigations in Geophysics no. 2, p. 1-30. 
Figure 9. Borehole geophysical logs for stratigraphic test well 1--(A) natural gamma radiation, (B) acoustic velocity, and $(\mathrm{C})$ single-point resistance and spontaneous potential. 


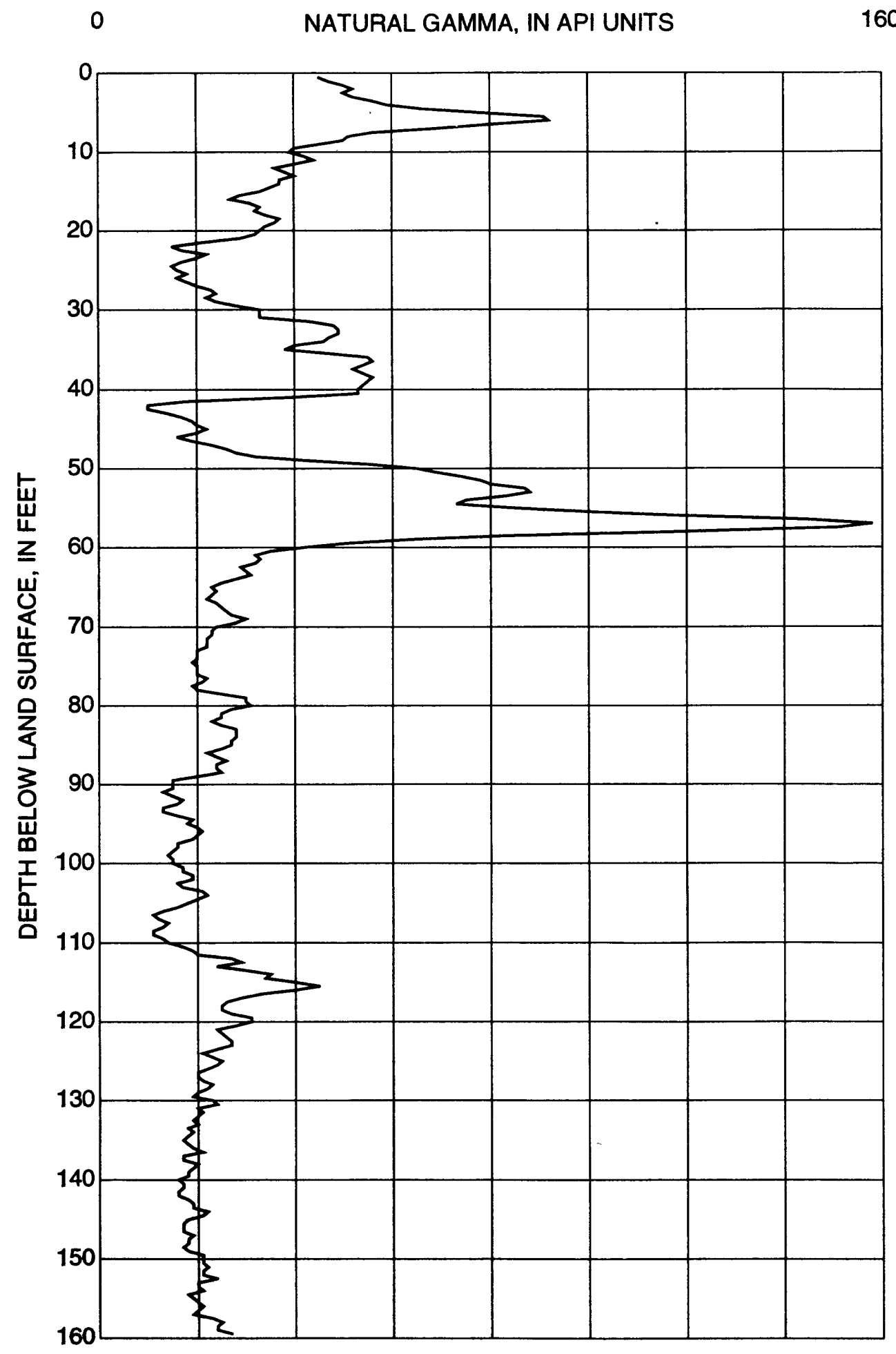

Figure 9-A. Natural gamma radiation.

Figure 9

59 


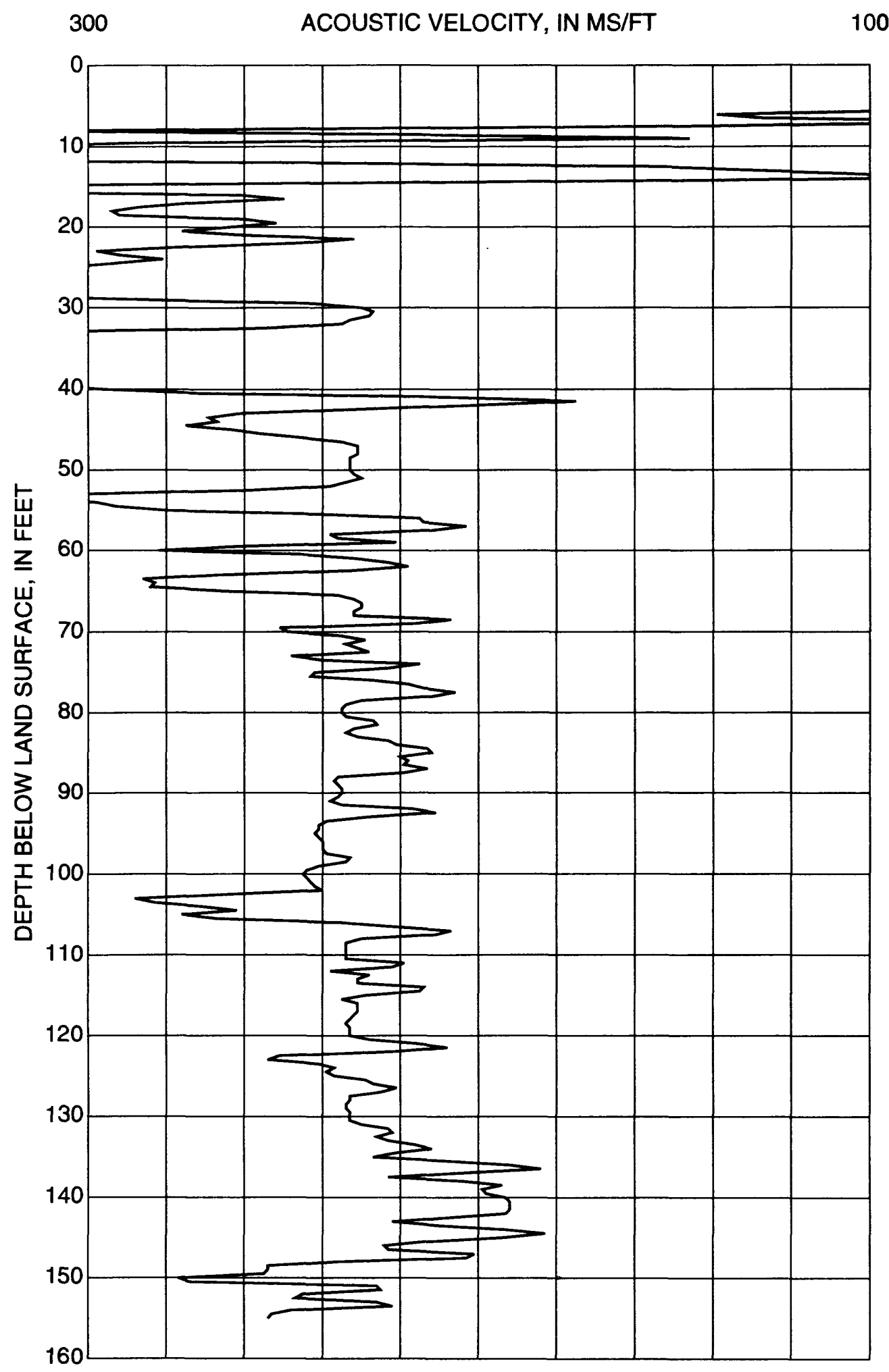

Figure 9-B. Acoustic velocity. 


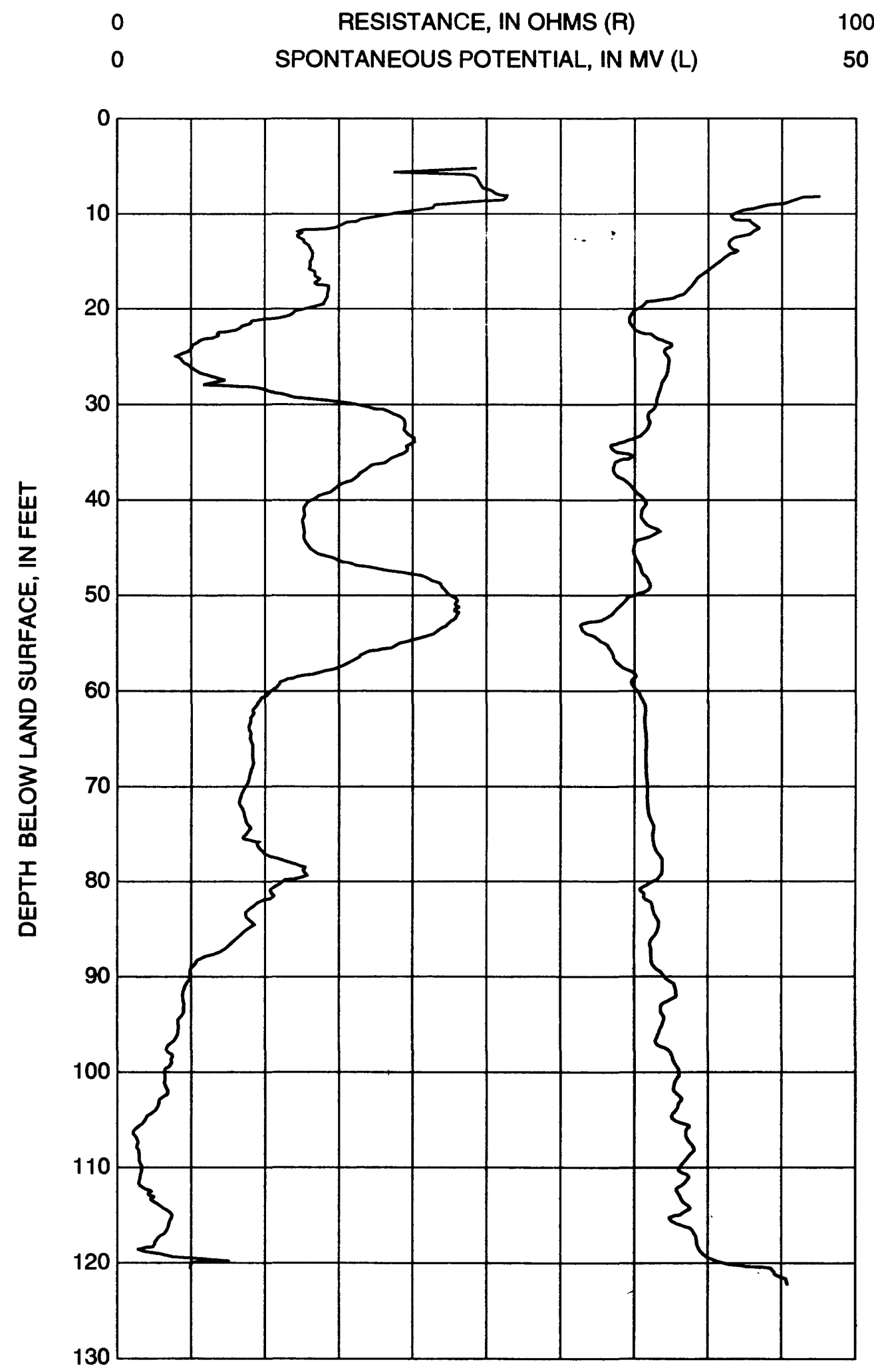

Figure 9-C. Single-point resistance and spontaneous potential. 
Figure 10. Borehole geophysical logs for stratigraphic test well 2--(A) natural gamma radiation, (B) acoustic velocity, (C) single-point resistance and spontaneous potential, (D) guard log (focused resistivity), (E) caliper, and $(F)$ temperature. 


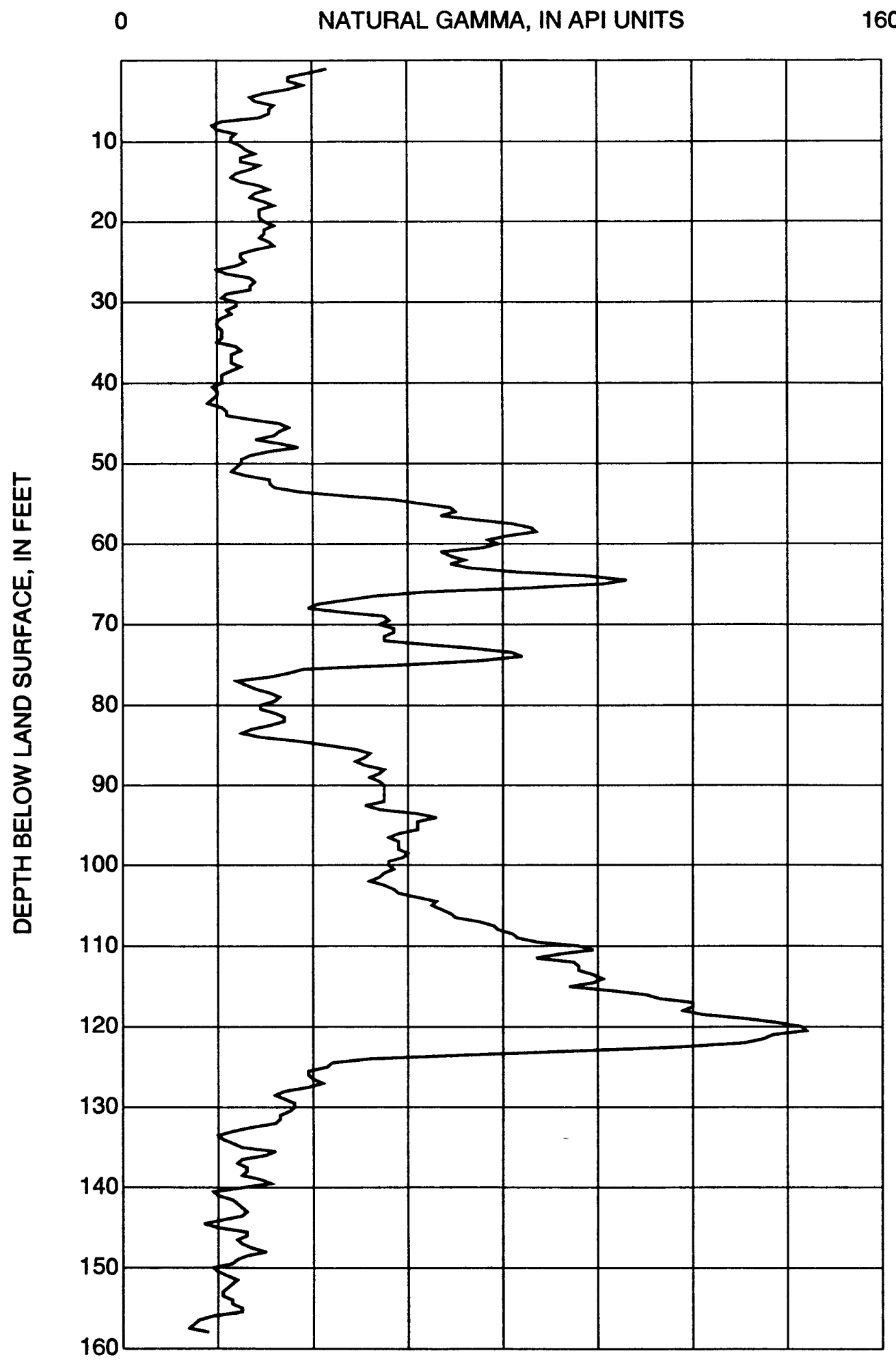

Figure 10-A. Natural gamma radiation.

Figure 10

63 


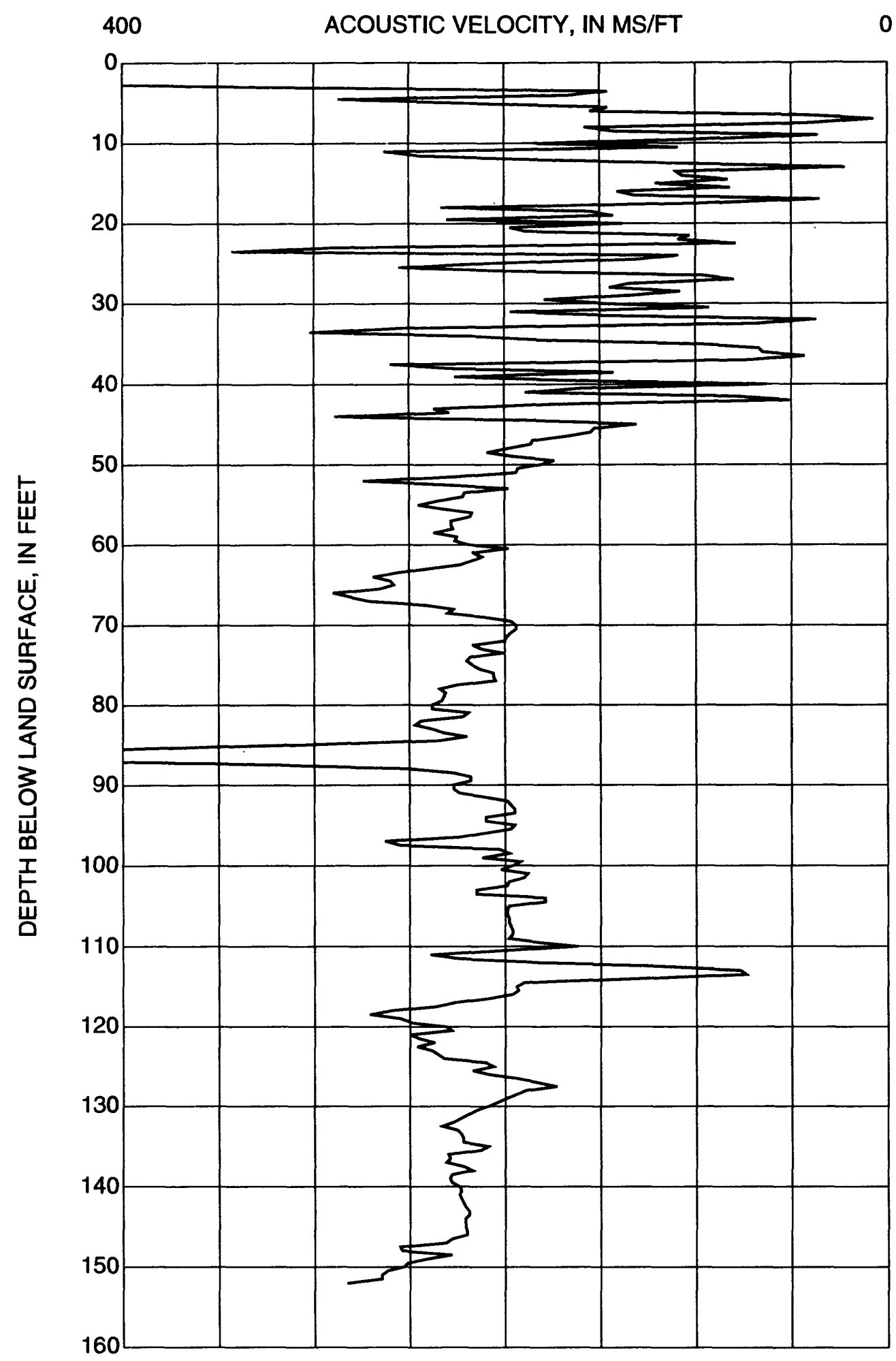

Figure 10-B. Acoustic velocity. 


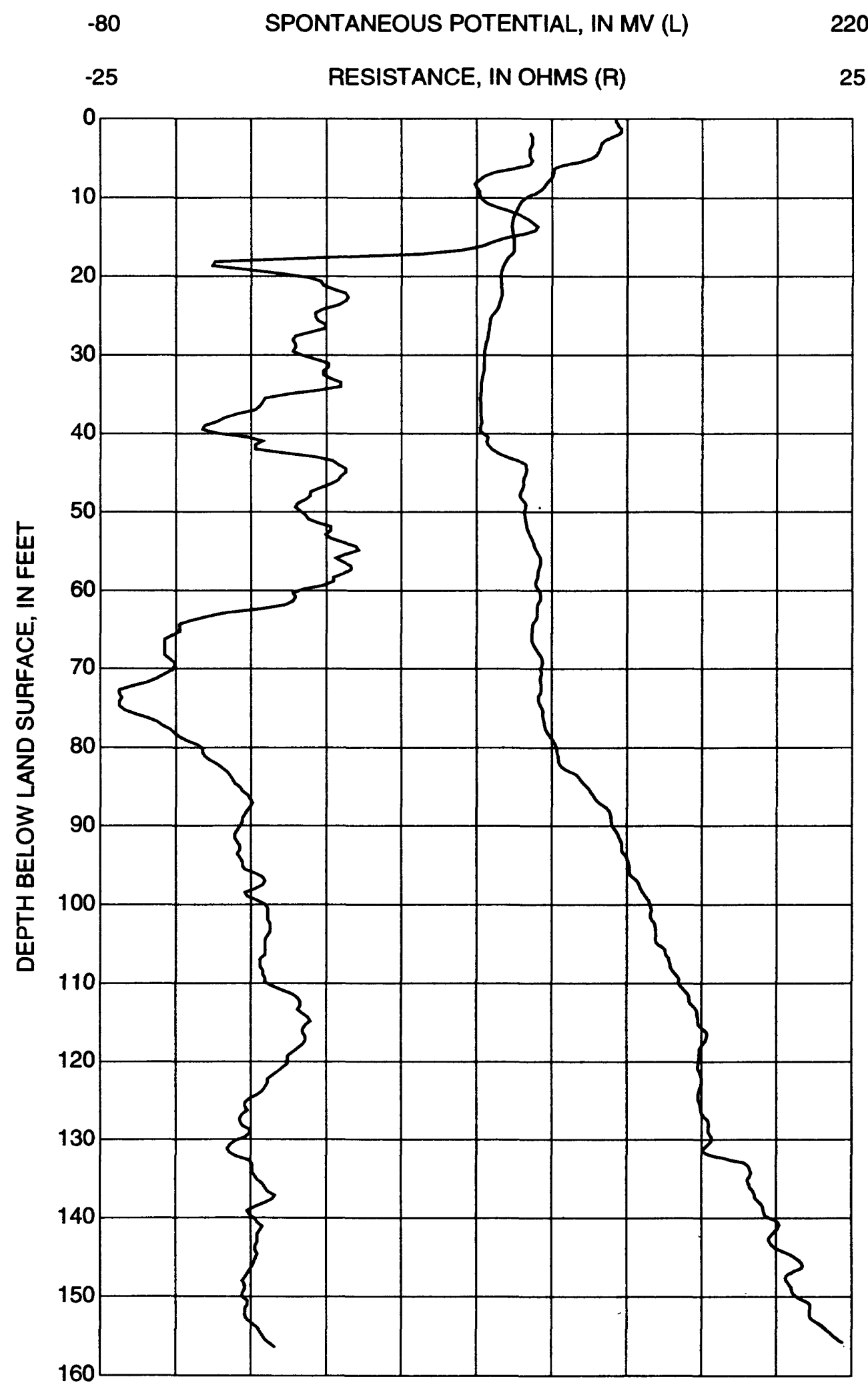

Figure 10-C. Single-point resistance and spontaneous potential. 


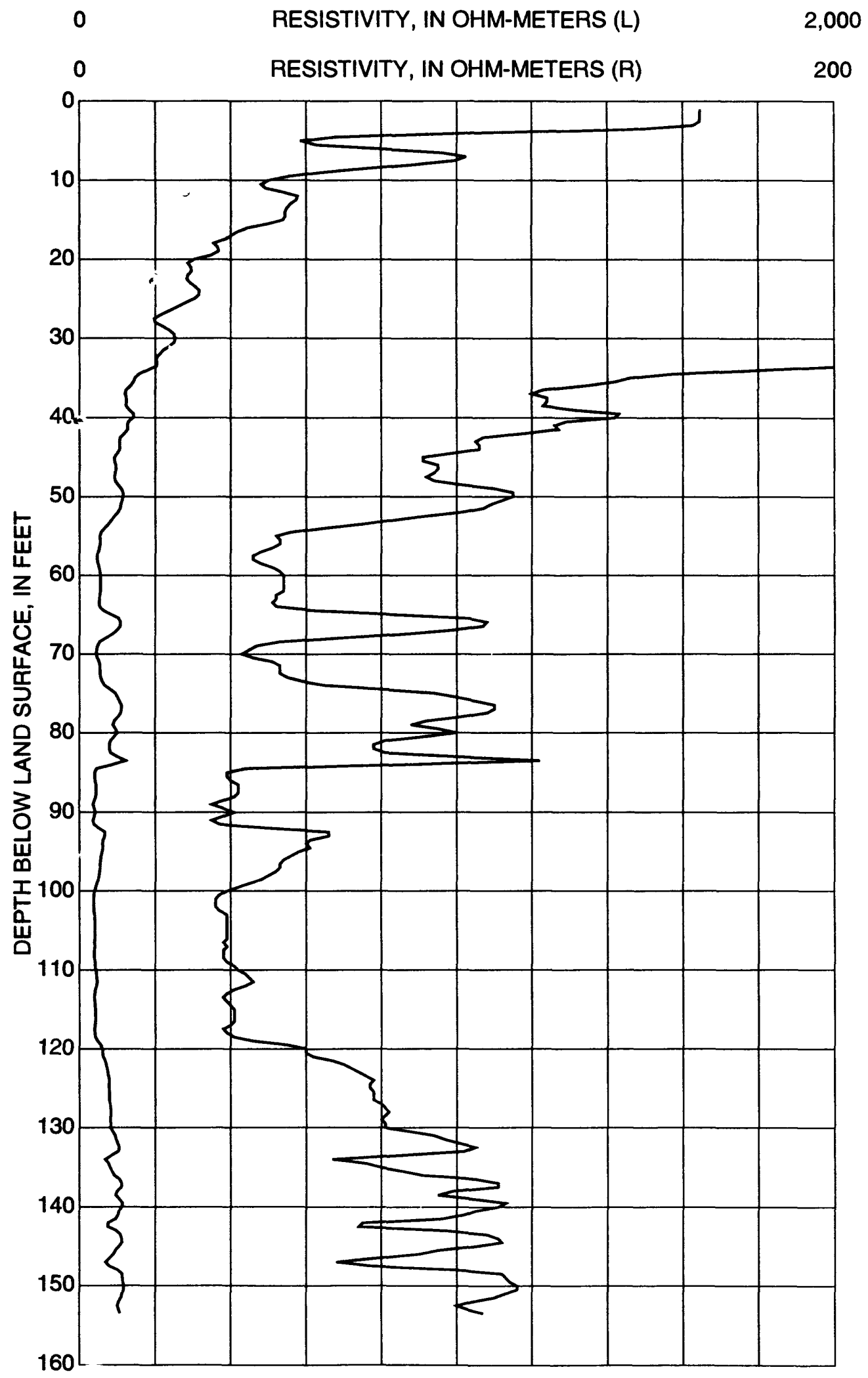

Figure 10-D. Guard log (focused resistivity). 


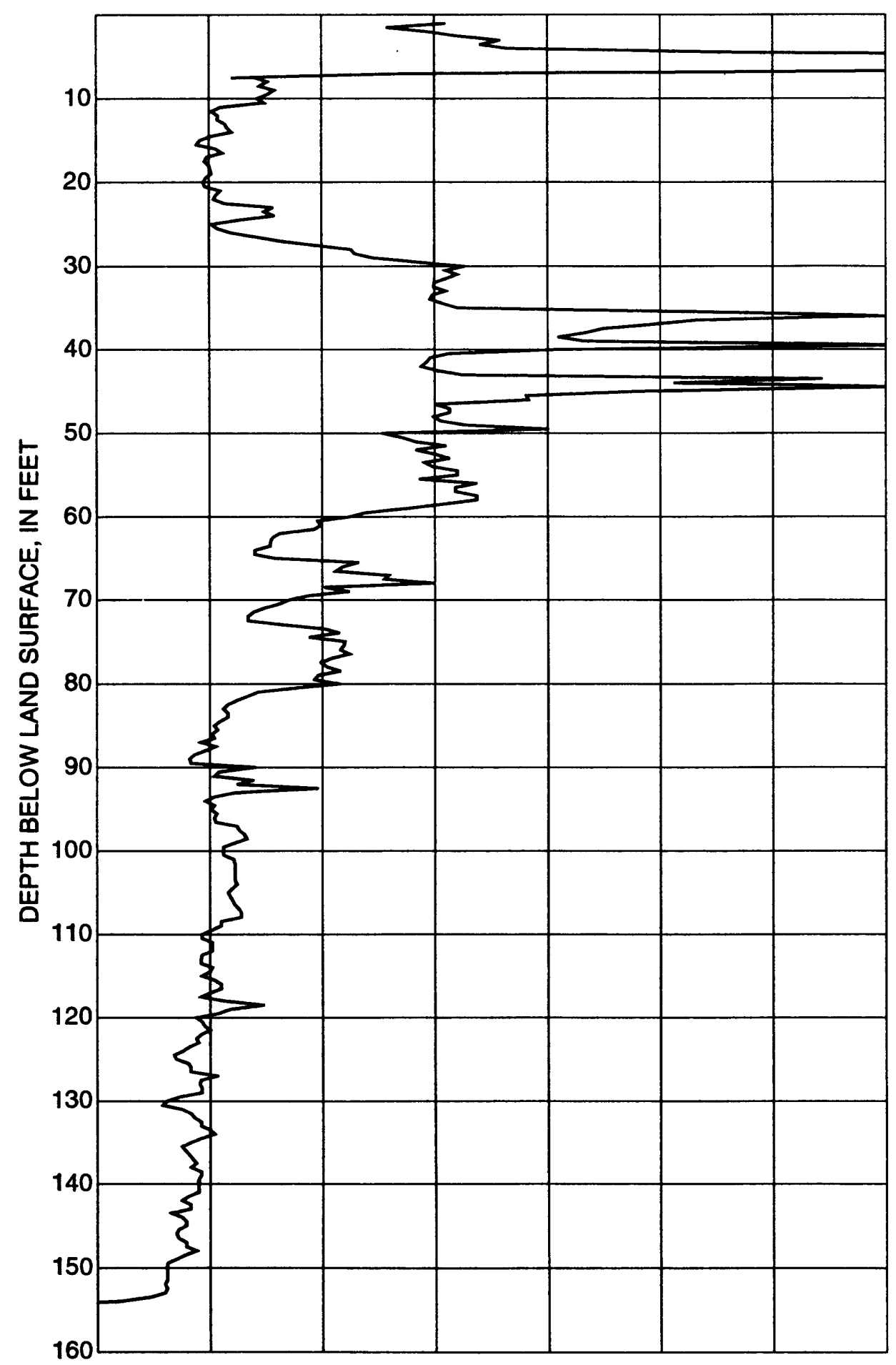

Figure 10-E. Caliper. 
19.2

TEMPERATURE, IN DEGREES C

20.4

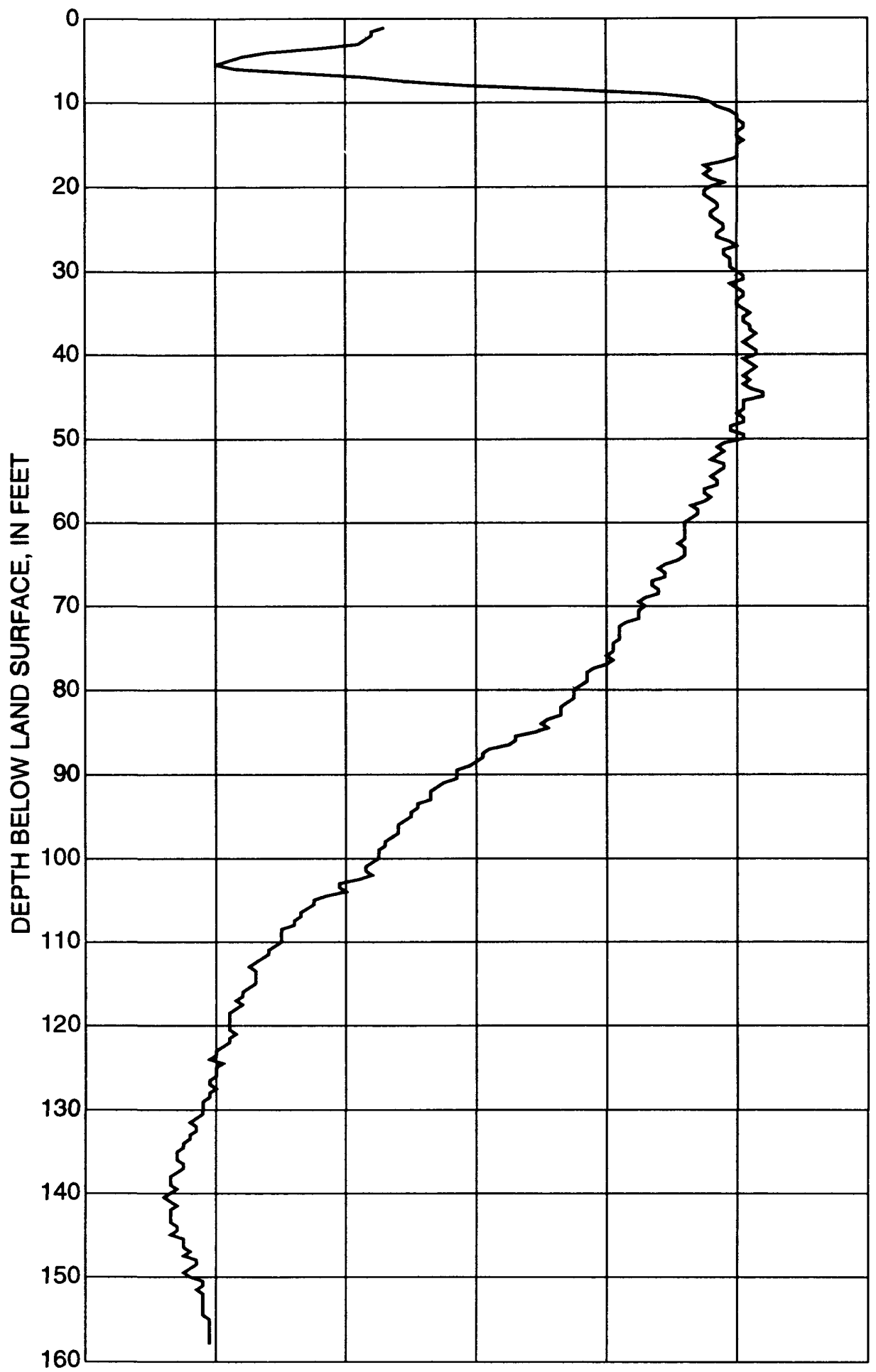

Figure 10-F. Temperature. 
Figure 11. Borehole geophysical logs for stratigraphic test well 3--(A) natural gamma radiation, (B) acoustic velocity, (C) single-point resistance and spontaneous potential, (D) guard log (focused resistivity), and (E) caliper. 


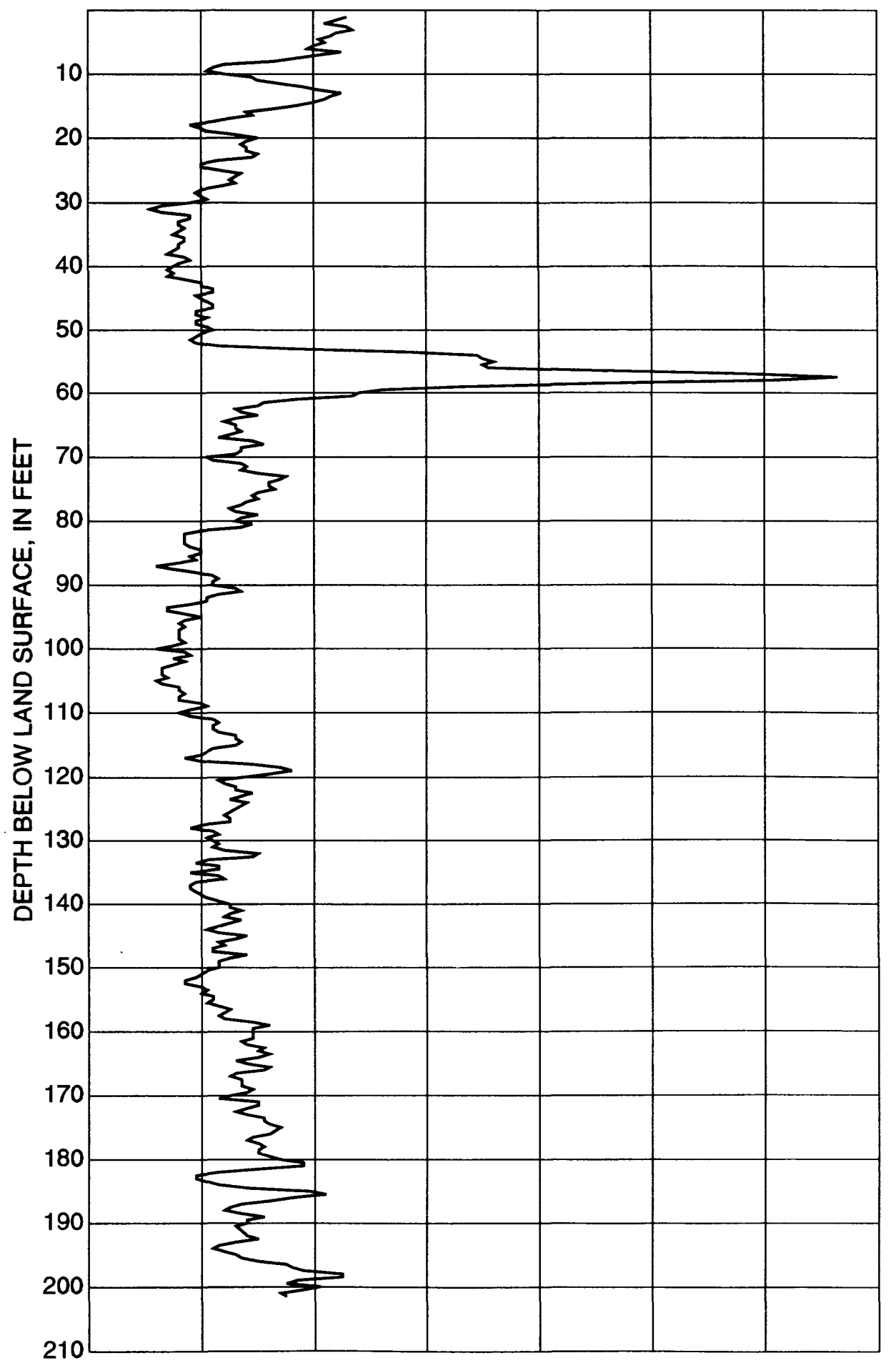

Figure 11-A. Natural gamma radiation. 


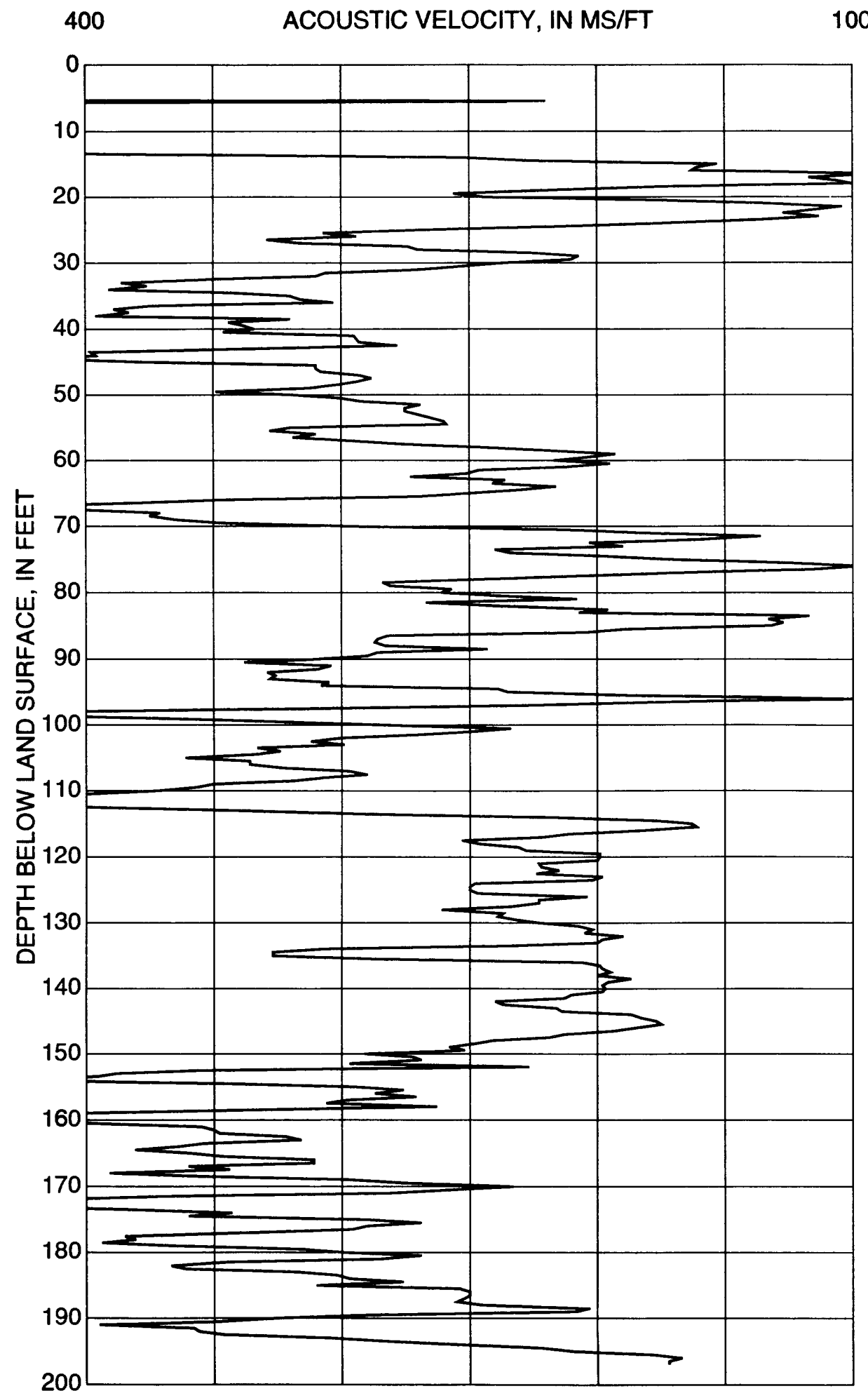

Figure 11-B. Acoustic velocity. 


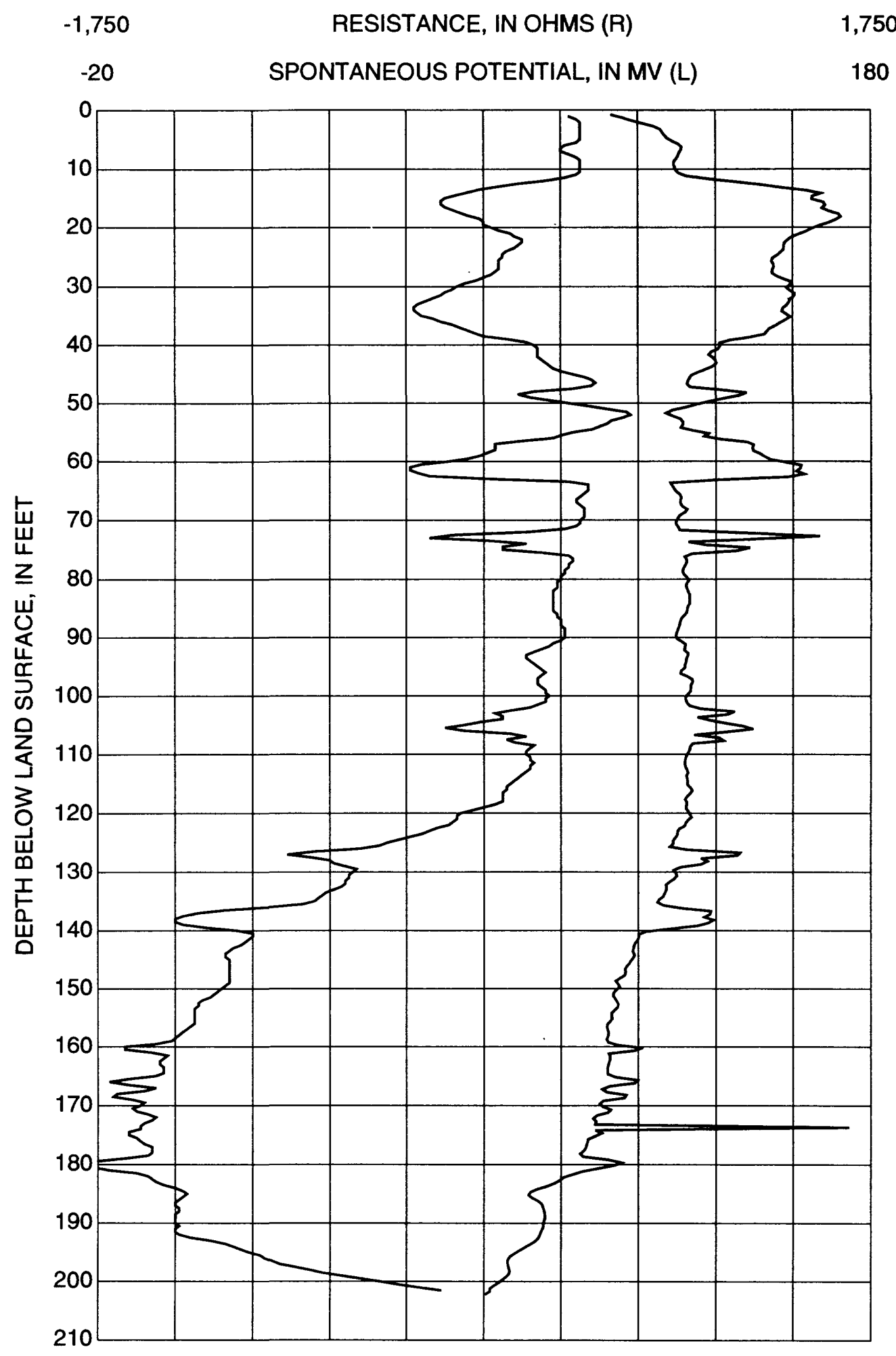

Figure 11-C. Single-point resistance and spontaneous potential. 
0

RESISTIVITY, IN OHMMETERS

280

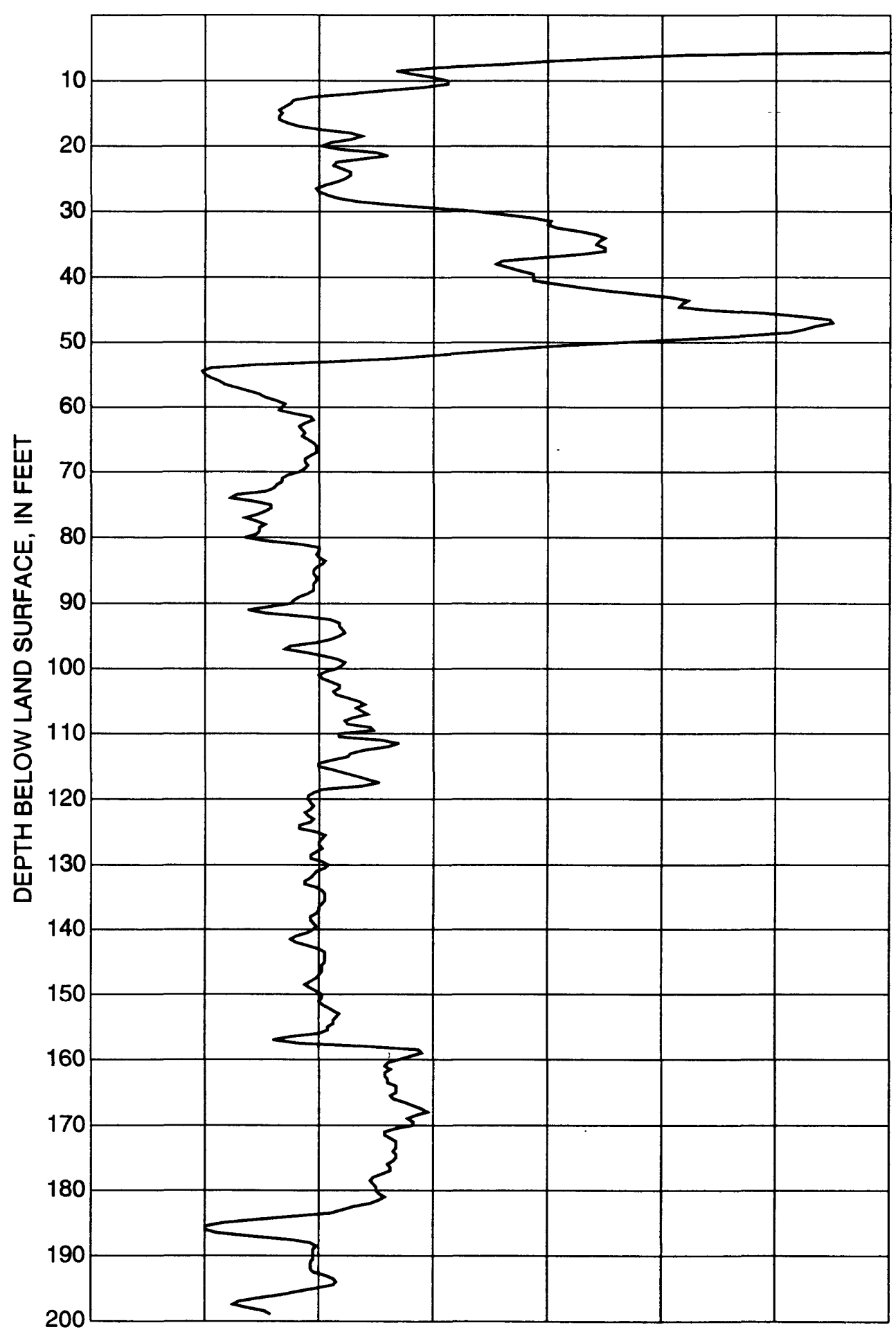

Figure 11-D. Guard log (focused resistivity).

Figure $11 \quad 73$ 


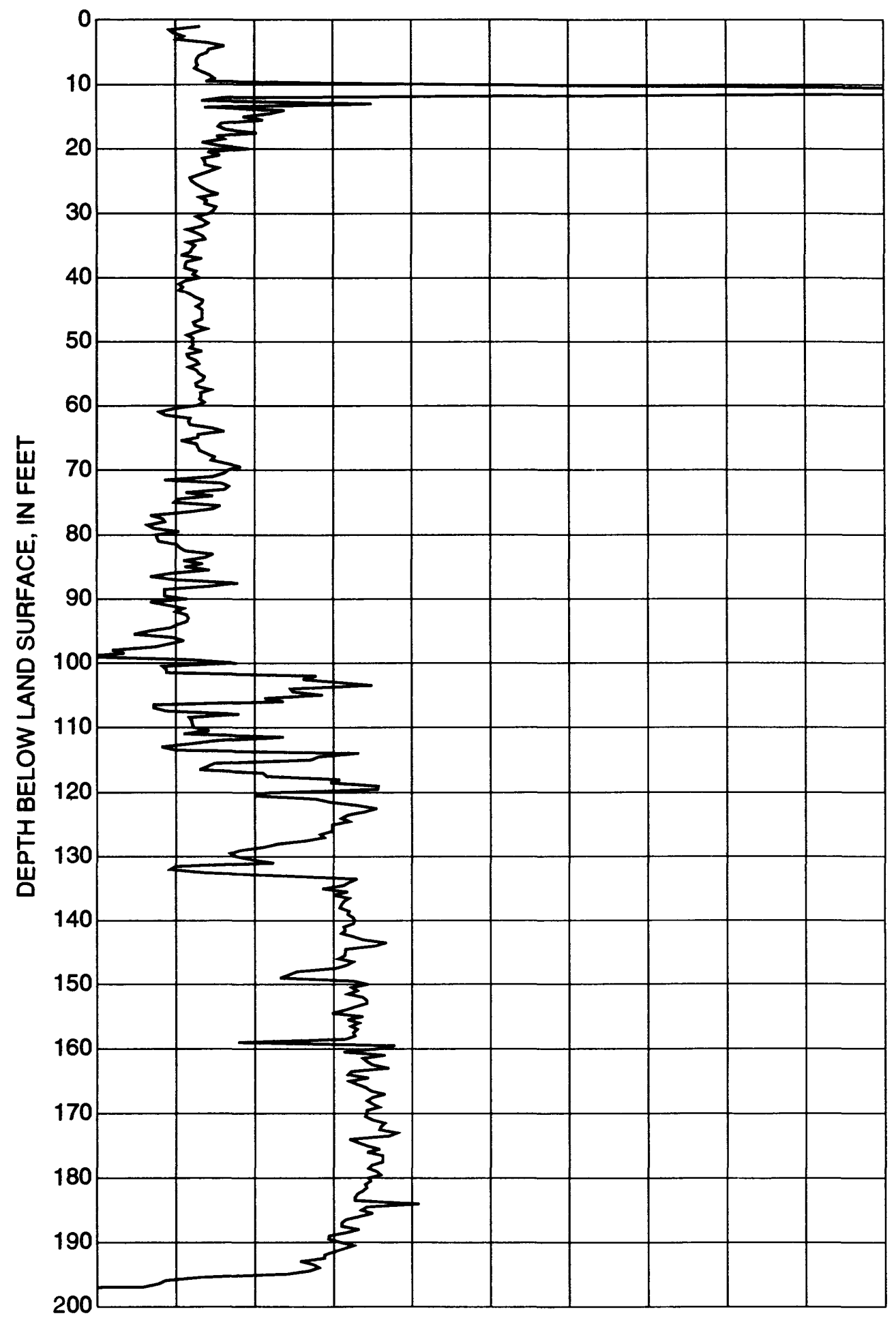

Figure 11-E. Caliper. 
Figure 12. Borehole geophysical logs for stratigraphic test well 4--(A) natural gamma radiation, and $(B)$ single-point resistance and spontaneous potential. 


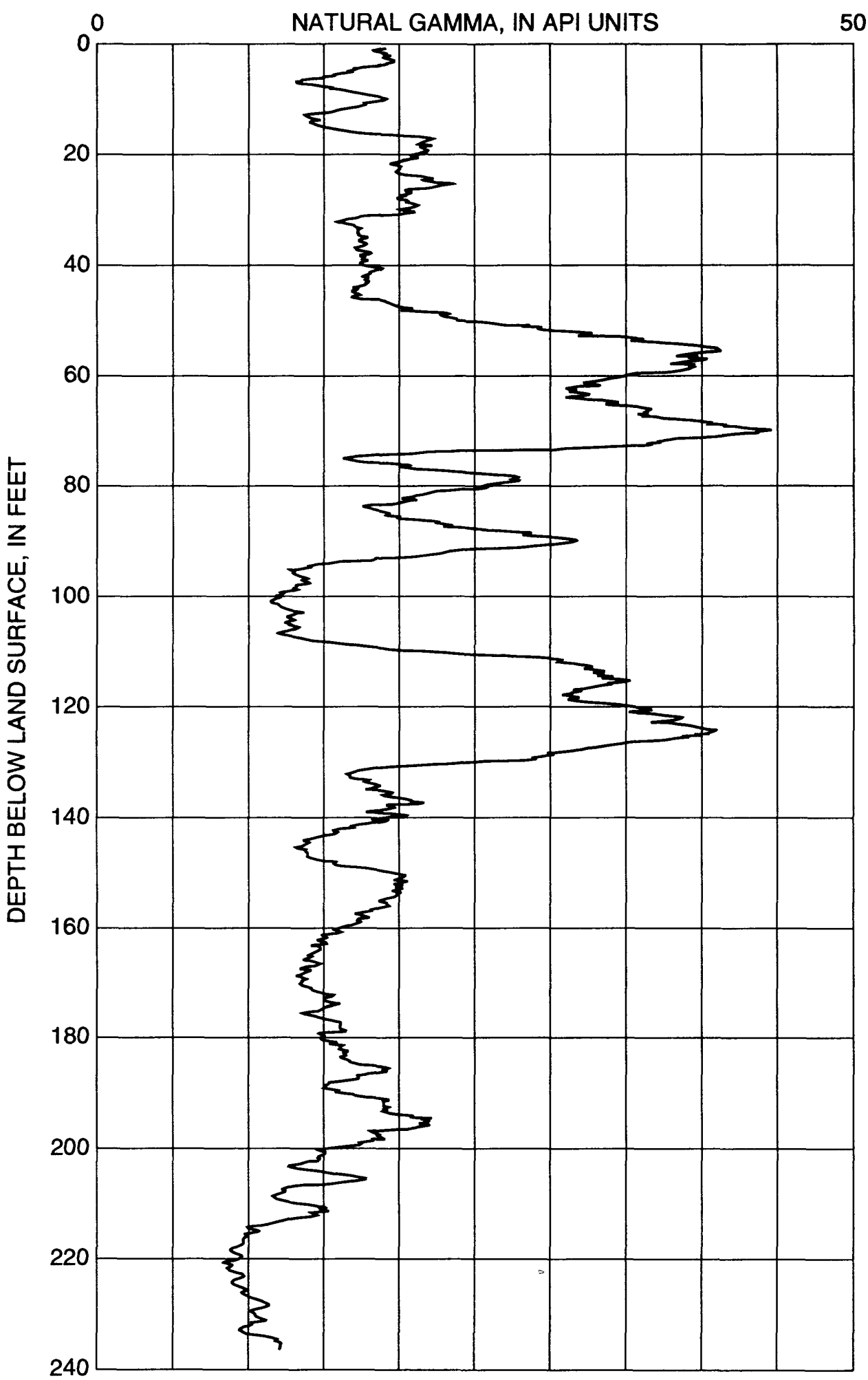

Figure 12-A. Natural gamma radiation. 


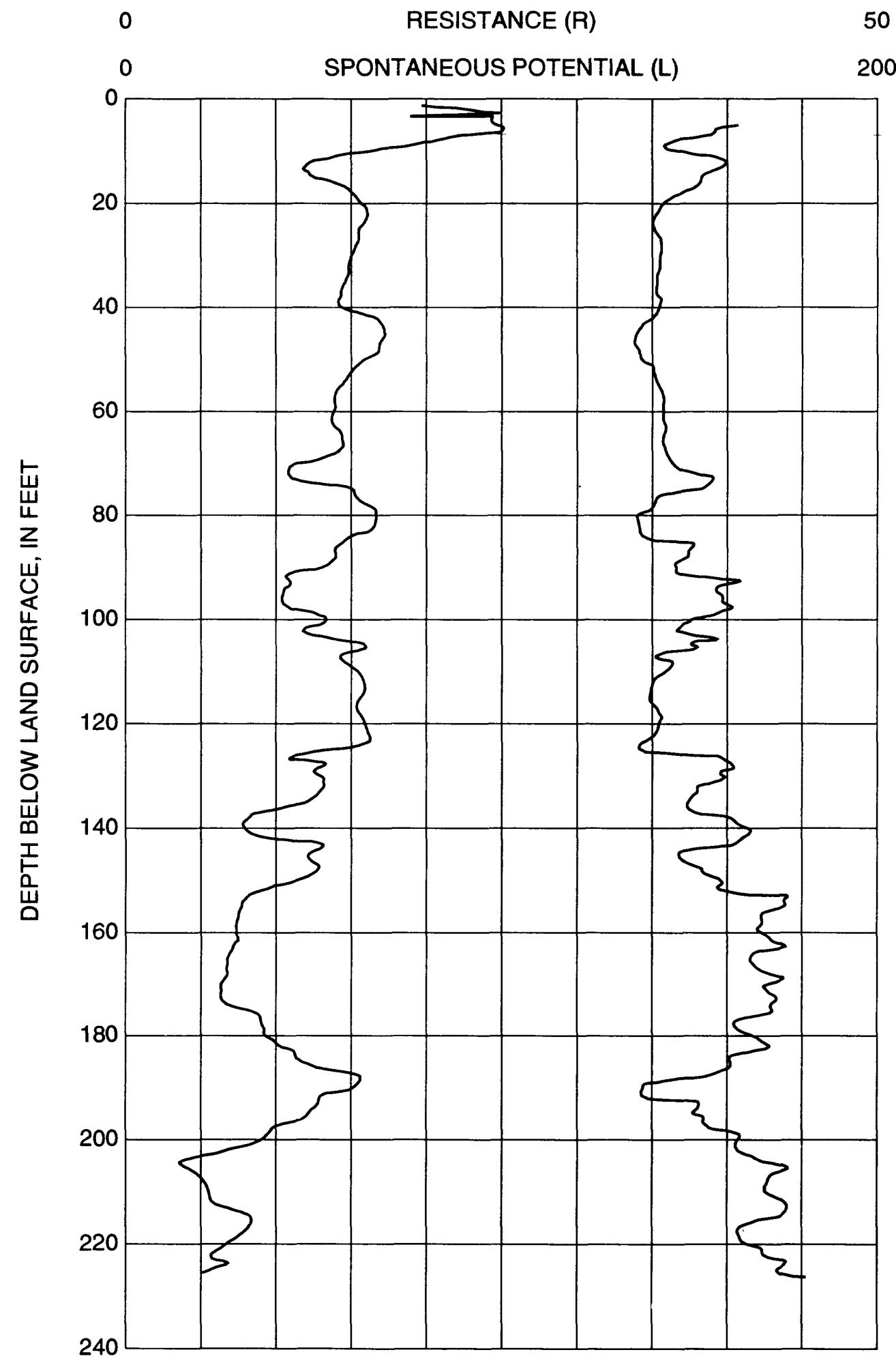

Figure 12-B. Single-point resistance and spontaneous potential. 
Figure 22. Composite marine seismic-reflection profile A-S along the south shore of the Neuse River north of Cherry Point Marine Corps Air Station. The composite profile has been divided into 18 sections at match points. 


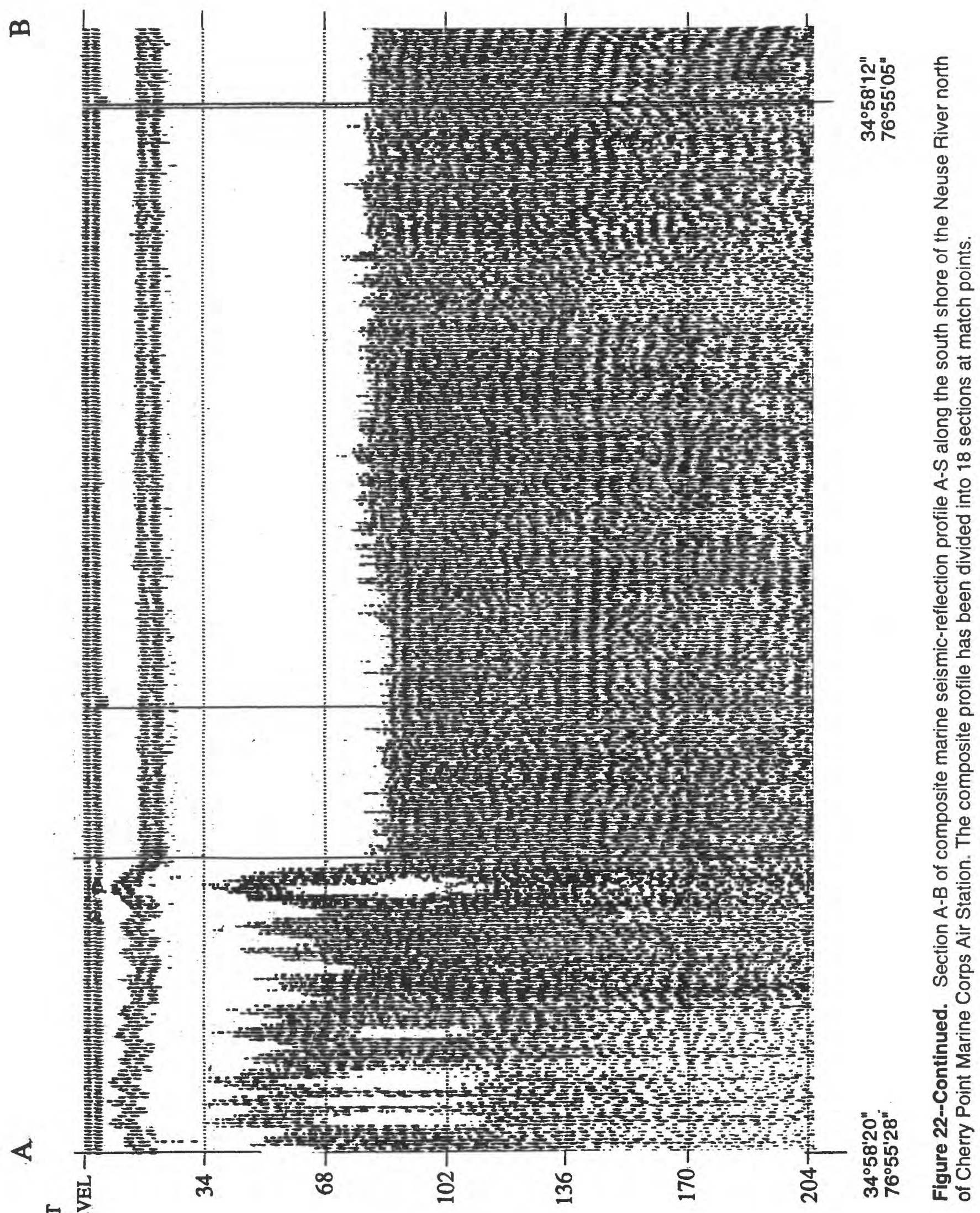




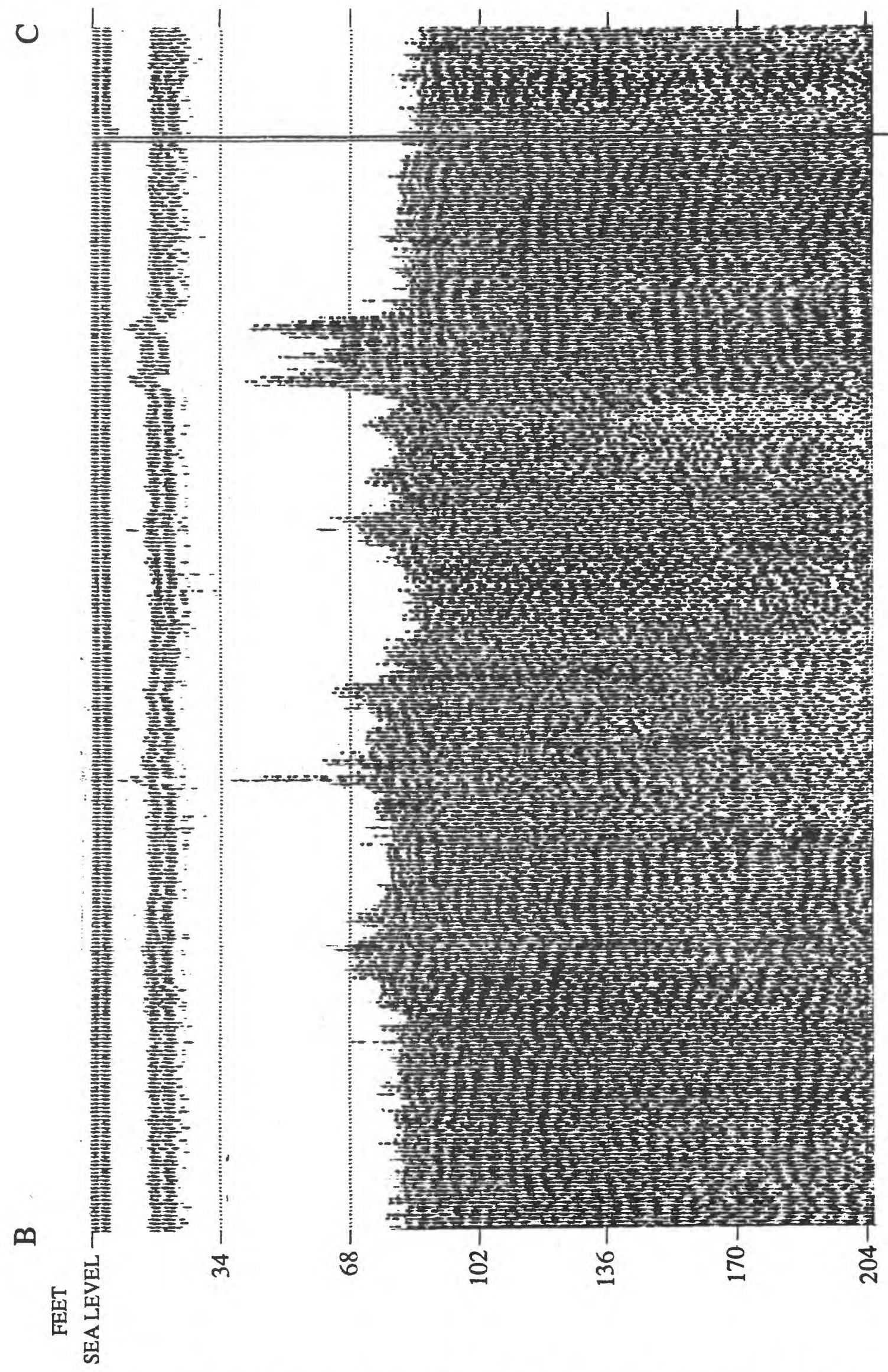

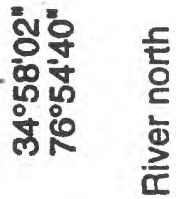

๑ั

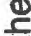

t

흥

동 둥

돈

品

논

을

드

$\infty$

$<0$

을

응 음

등

등

ळ

요

을

政

i 응

这

인

Еั

(4)

के

를

당

흐

บ

ตั

등

응

œ

ธ่ं

ํㅗㄹ

$\sum$

응

ป่ำ

สิ

히

등

한하 


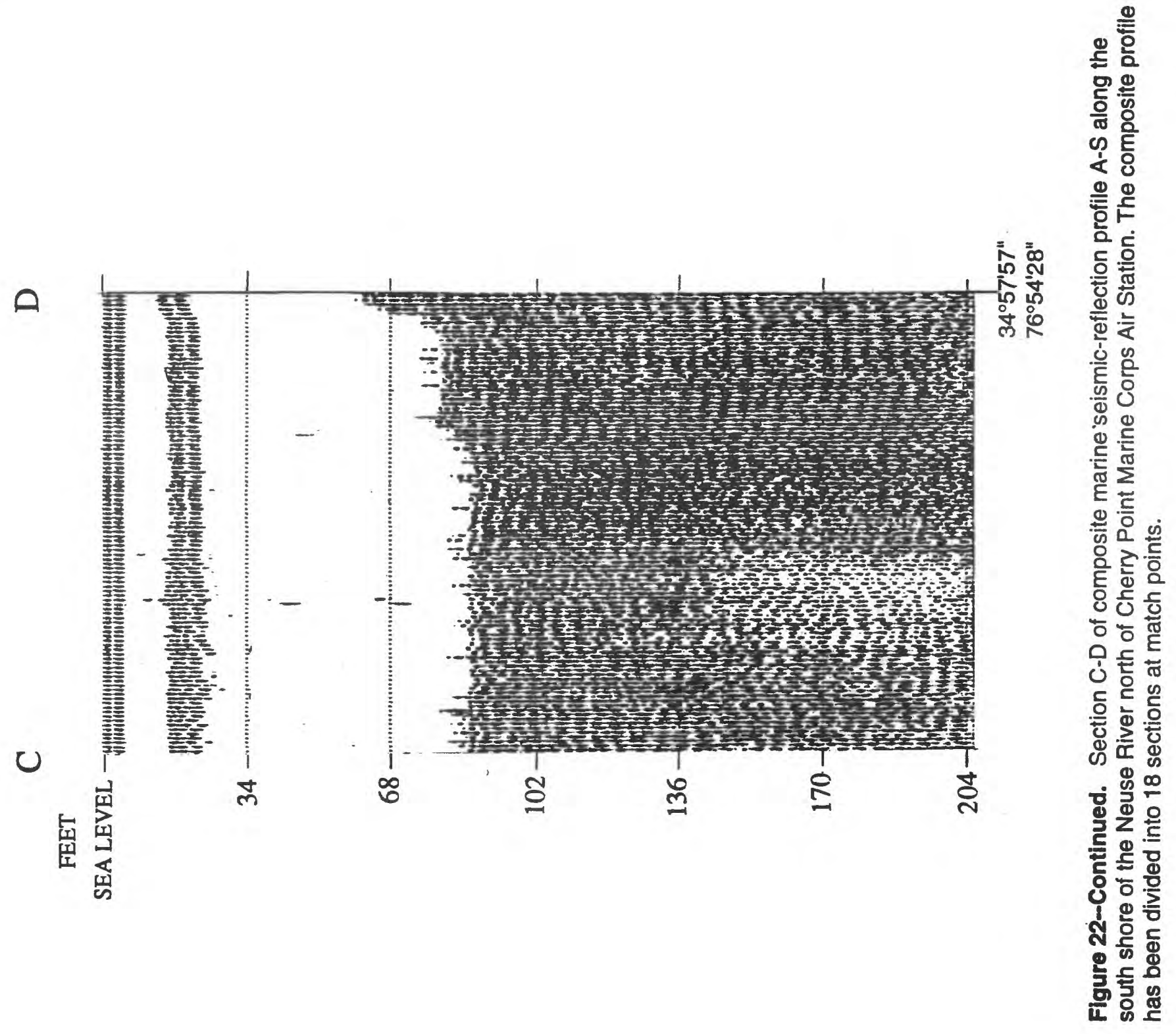




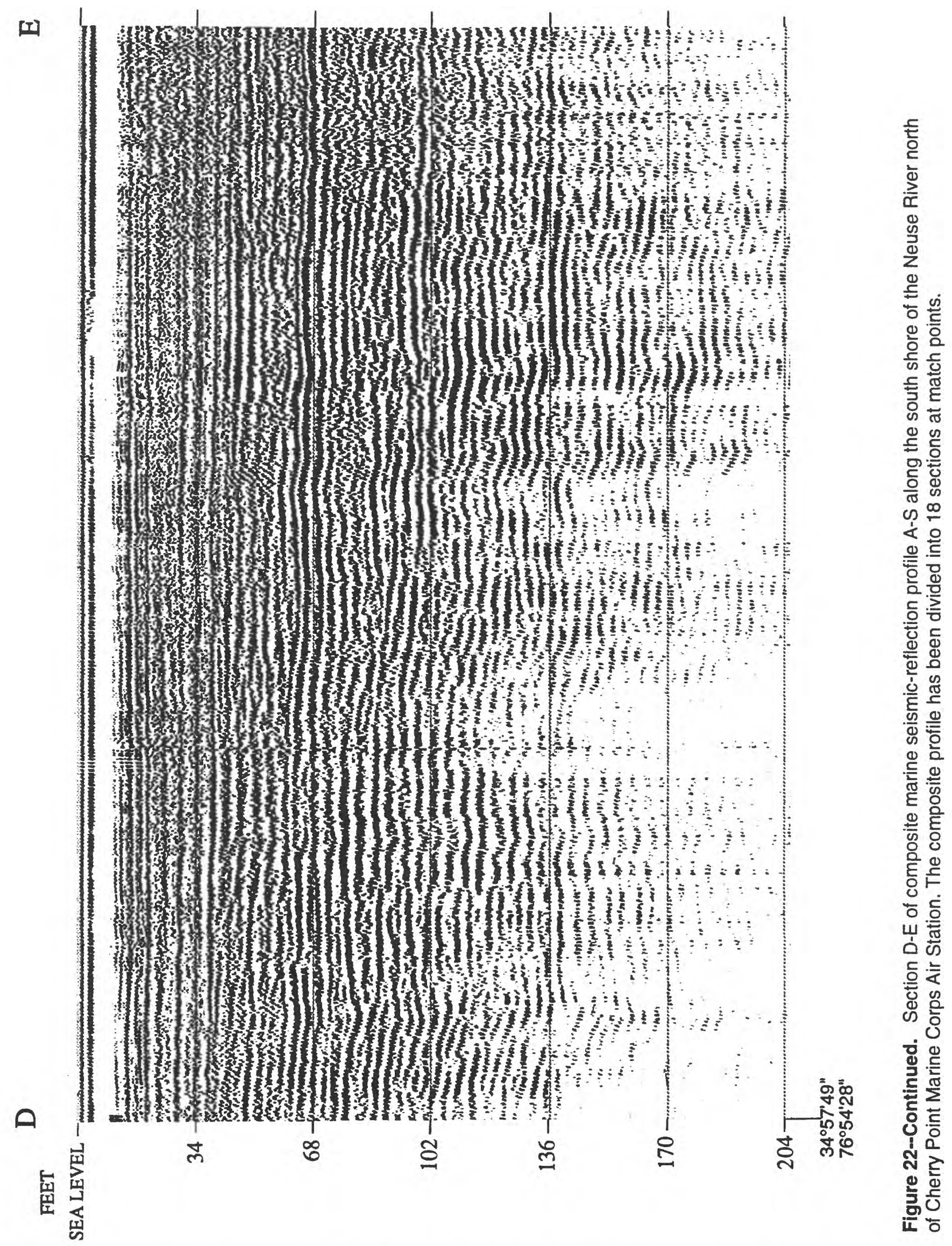




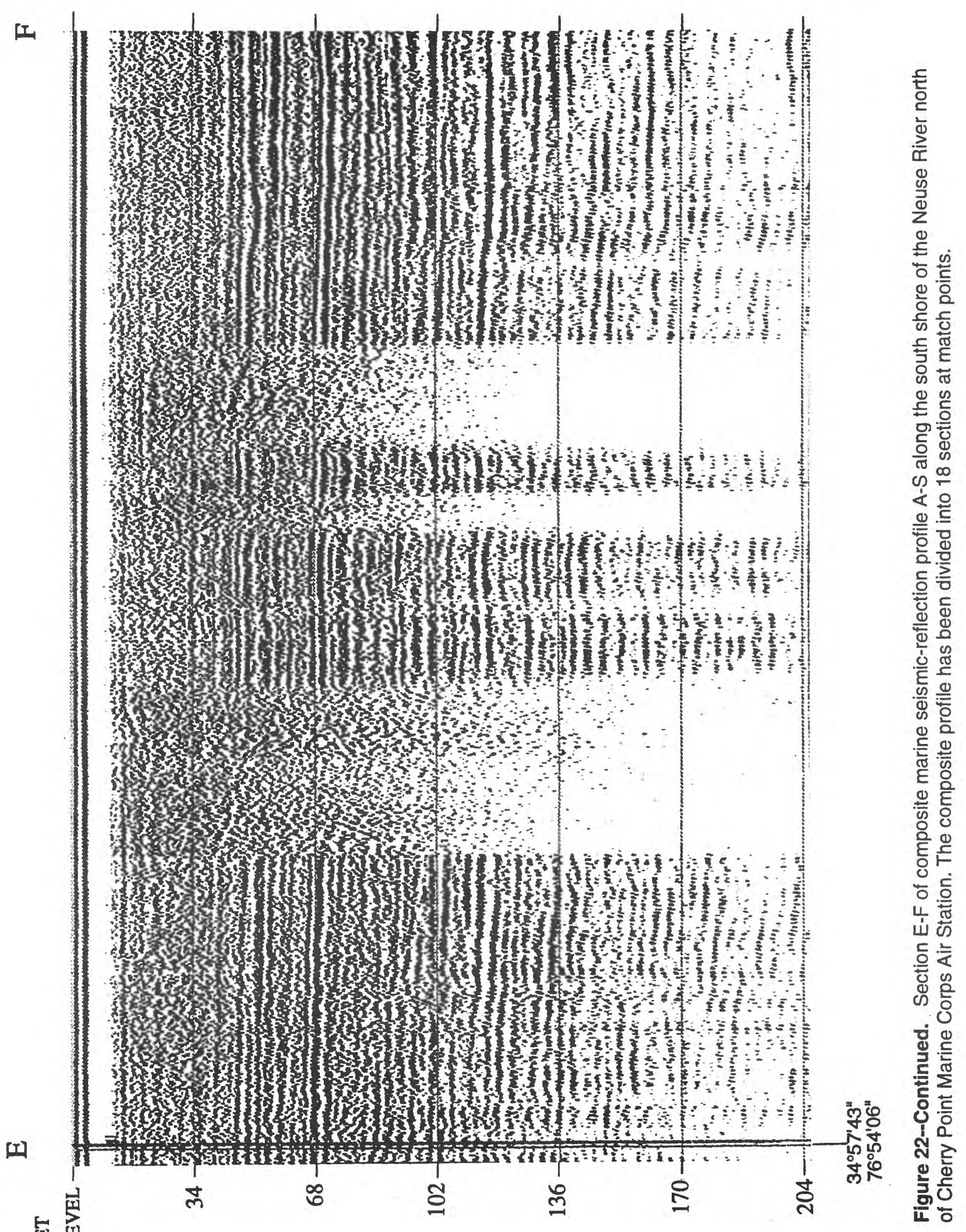




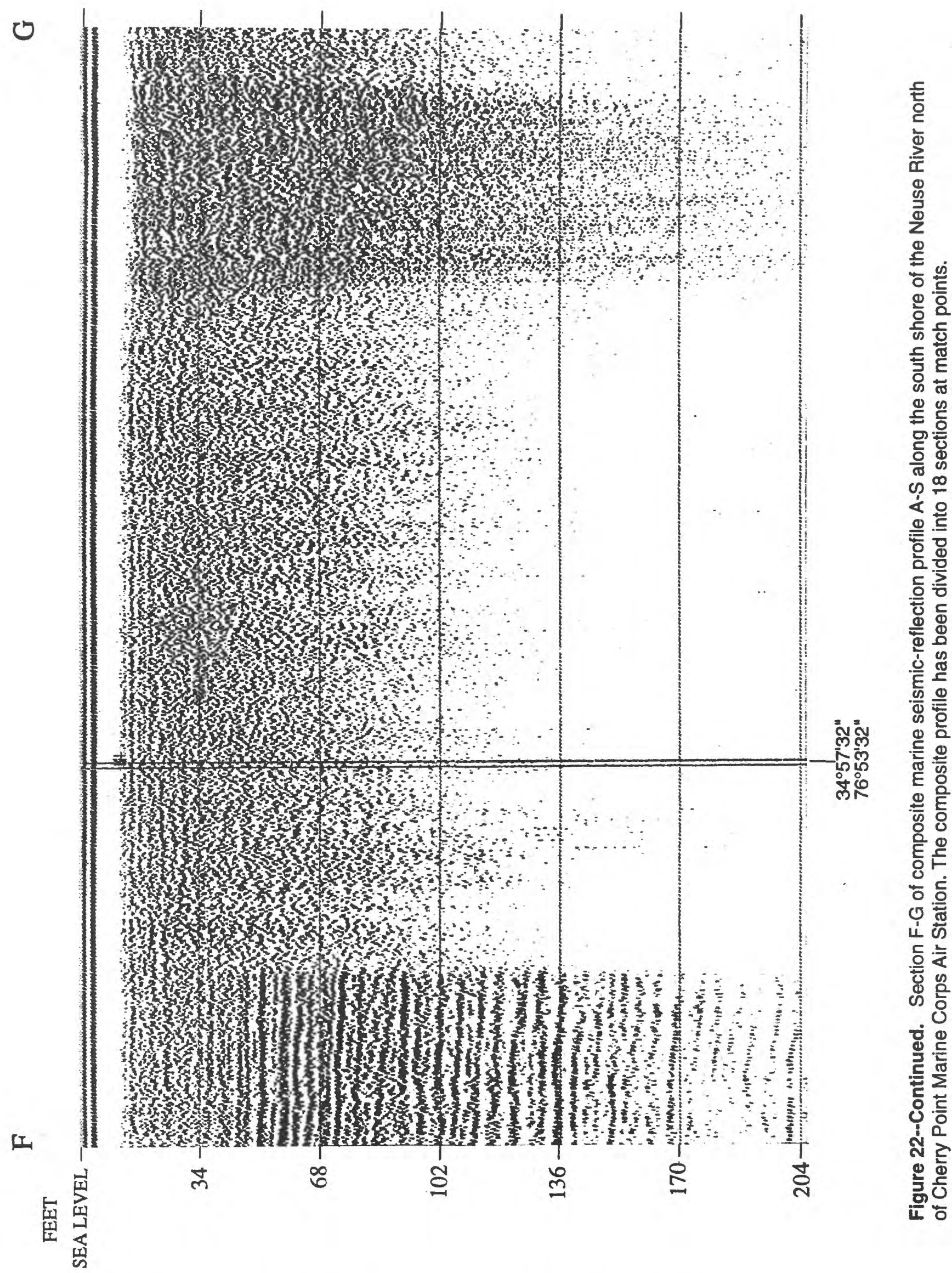




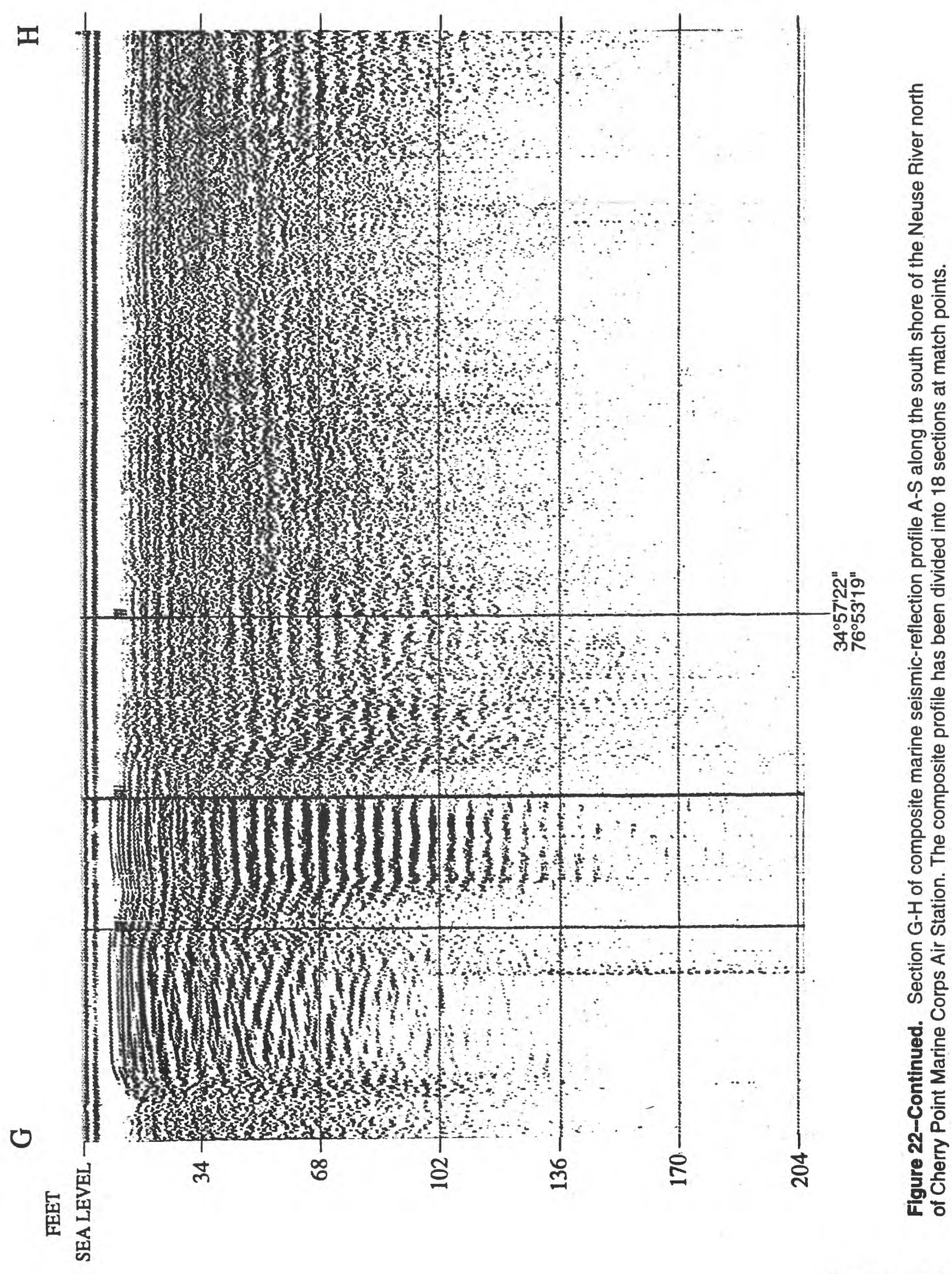




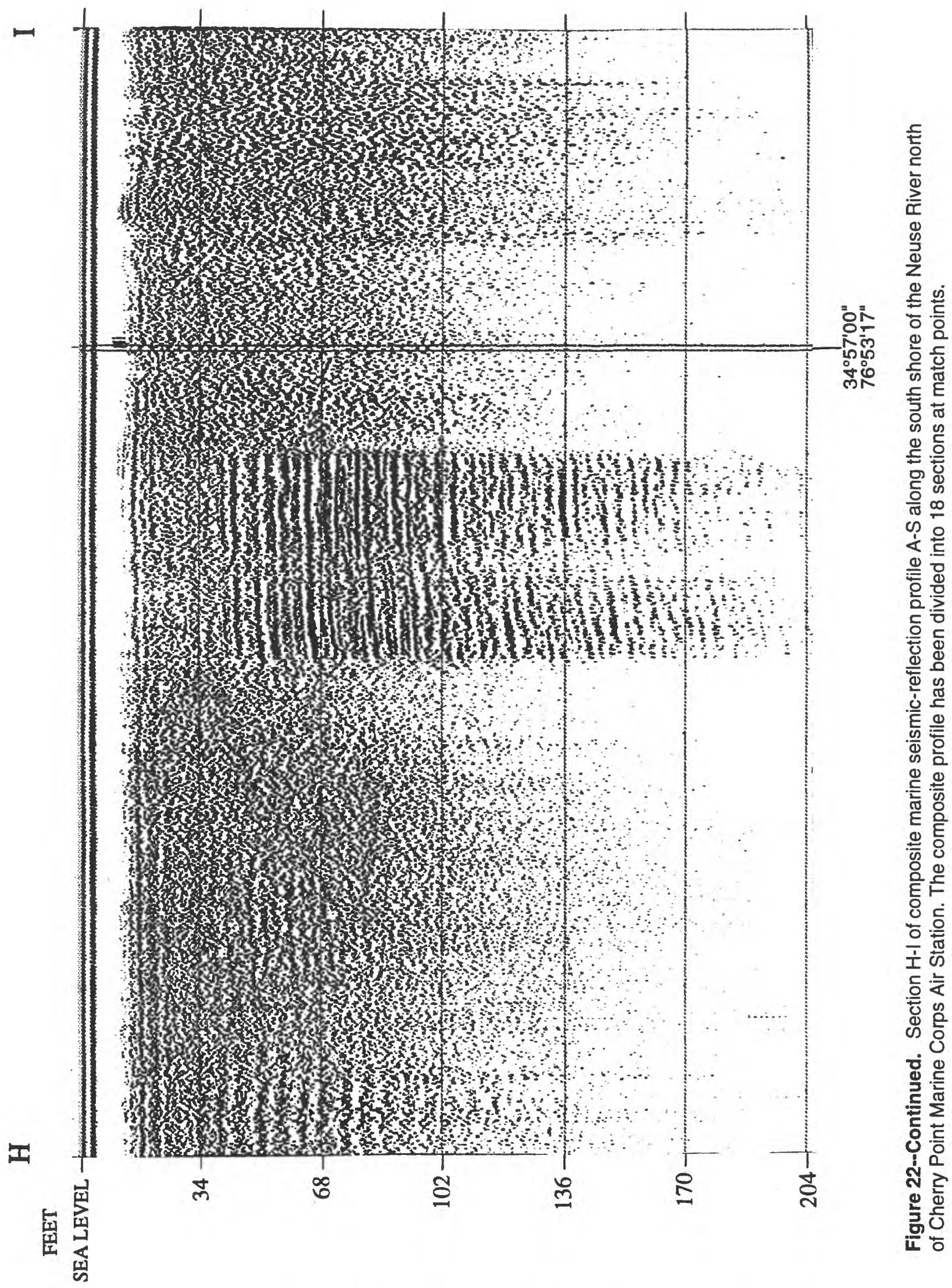




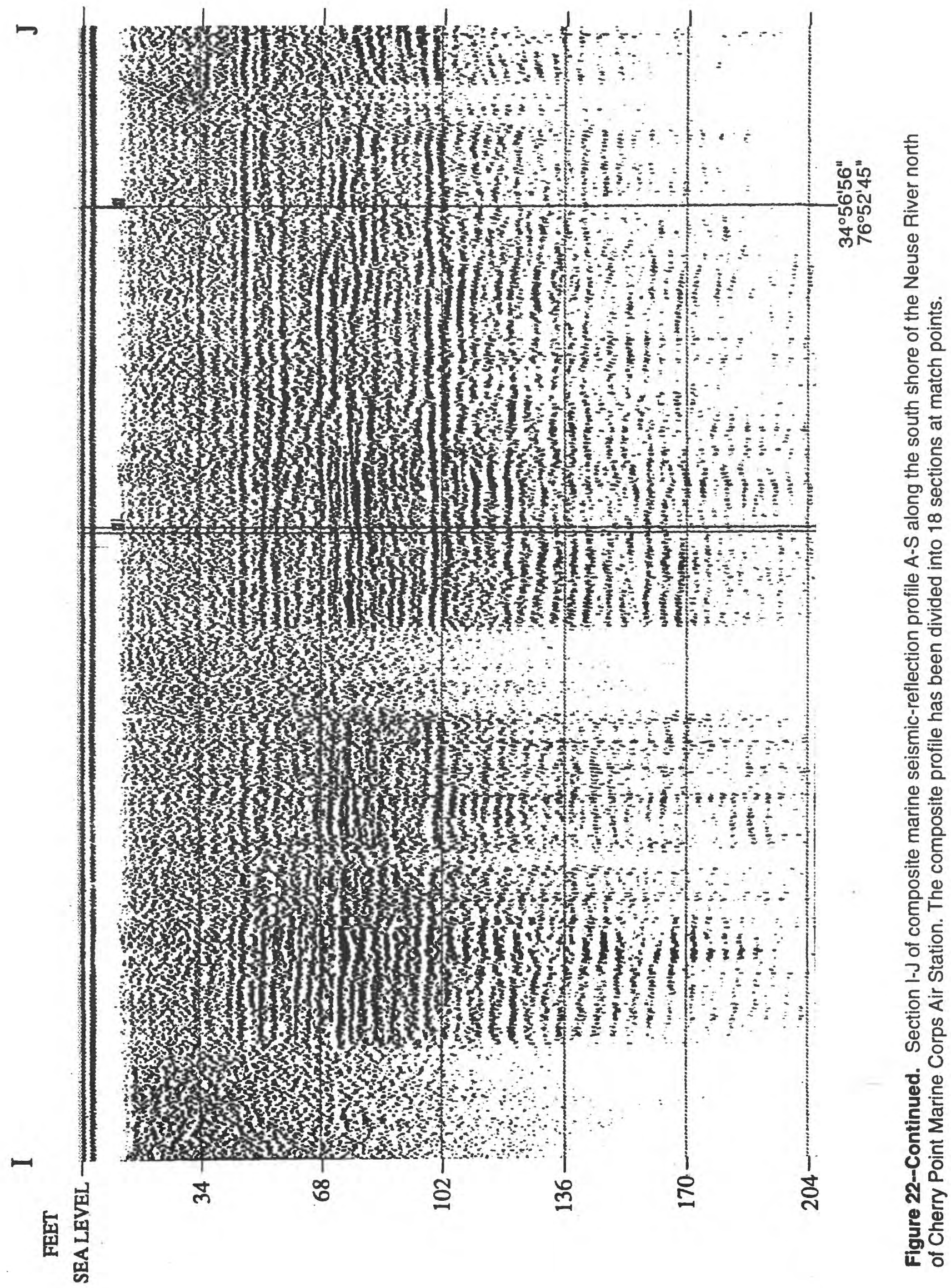




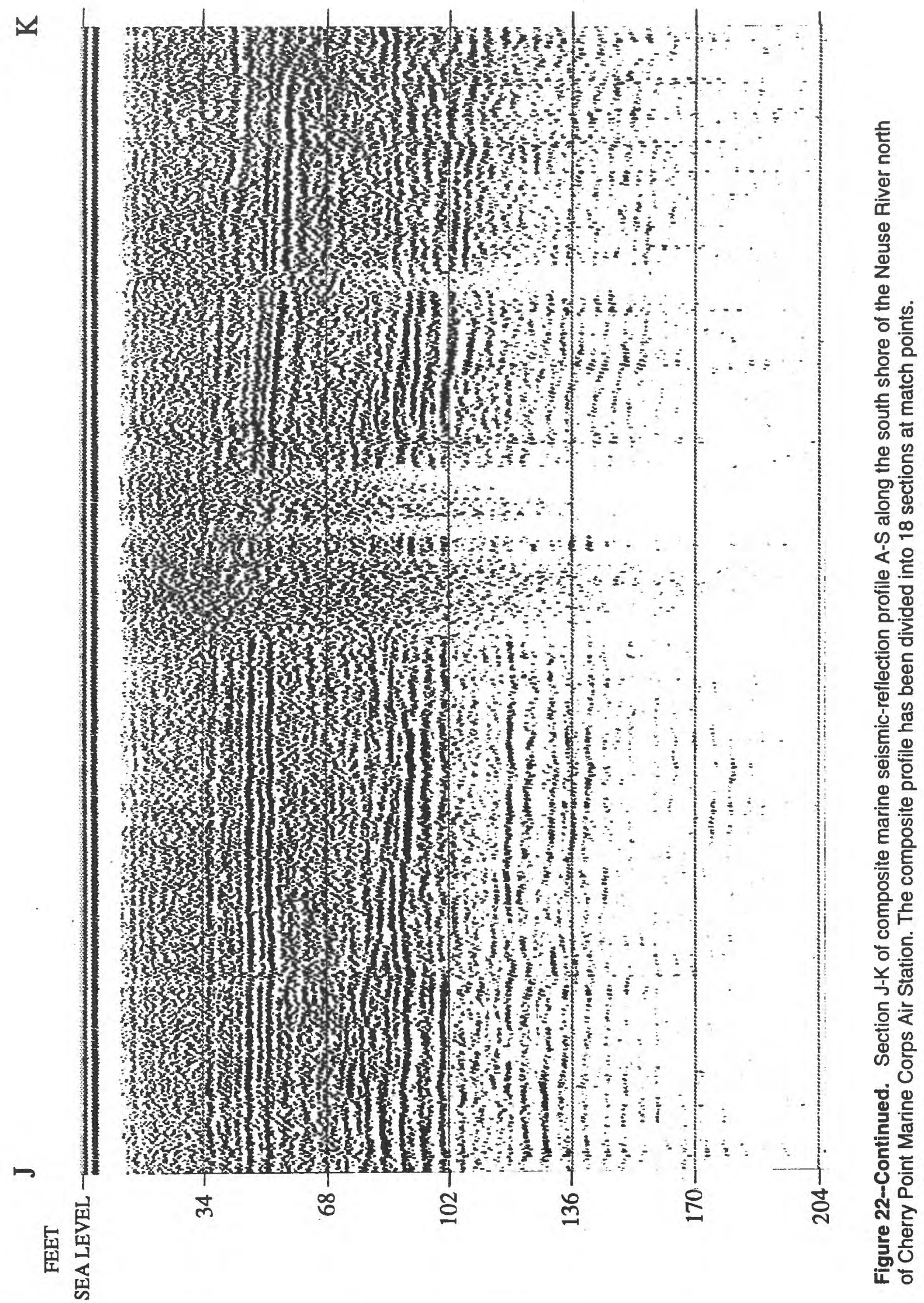




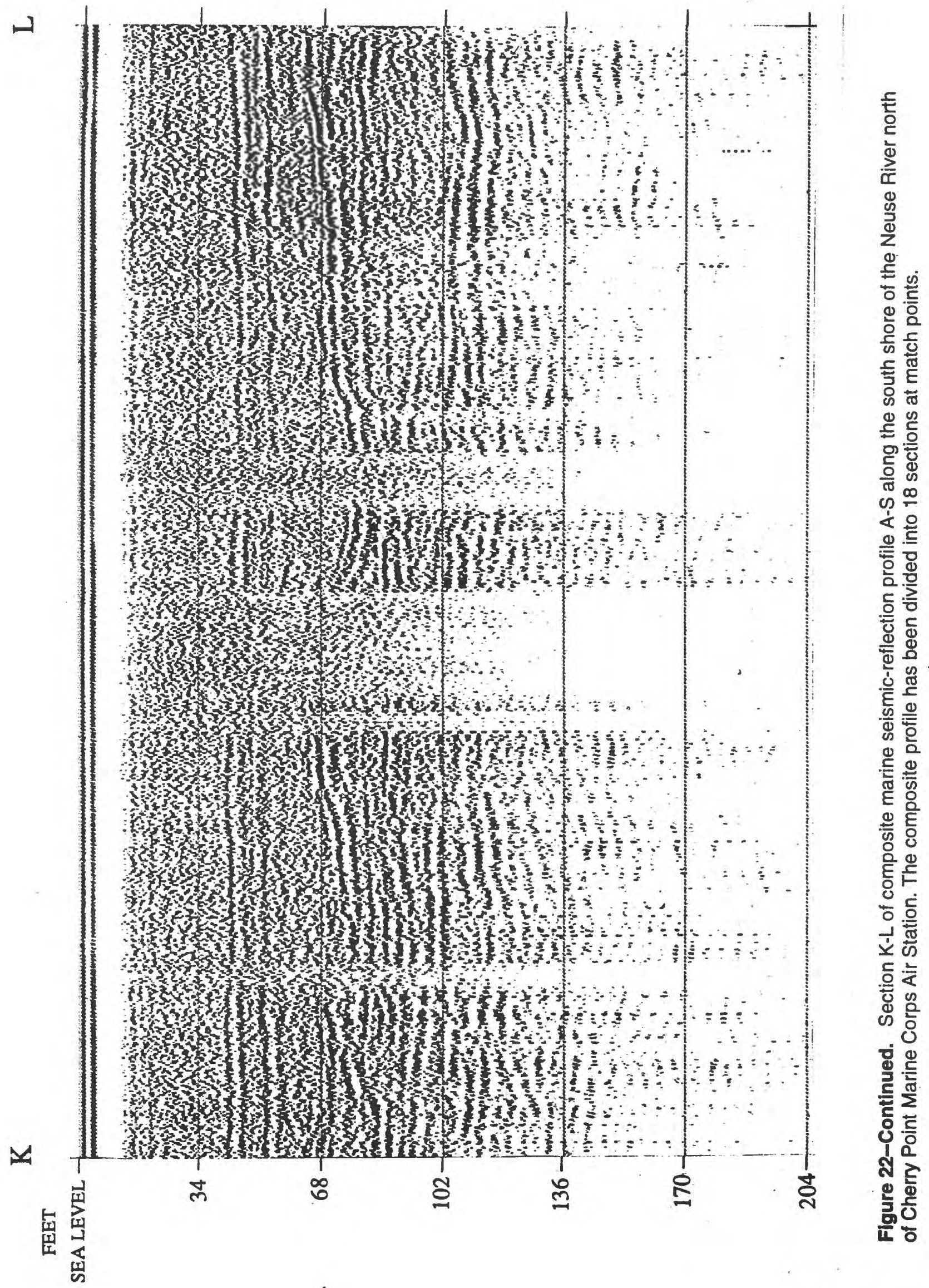




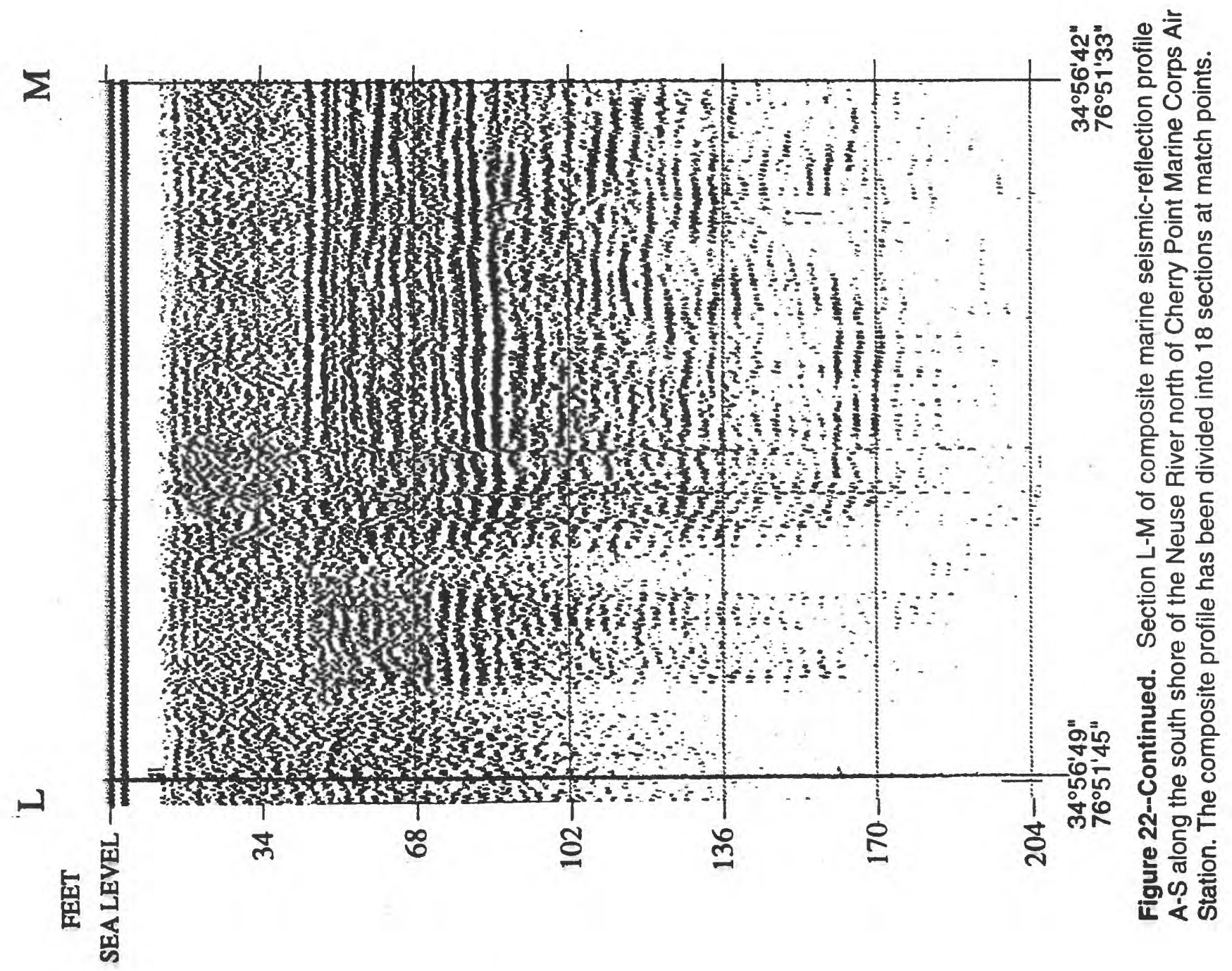




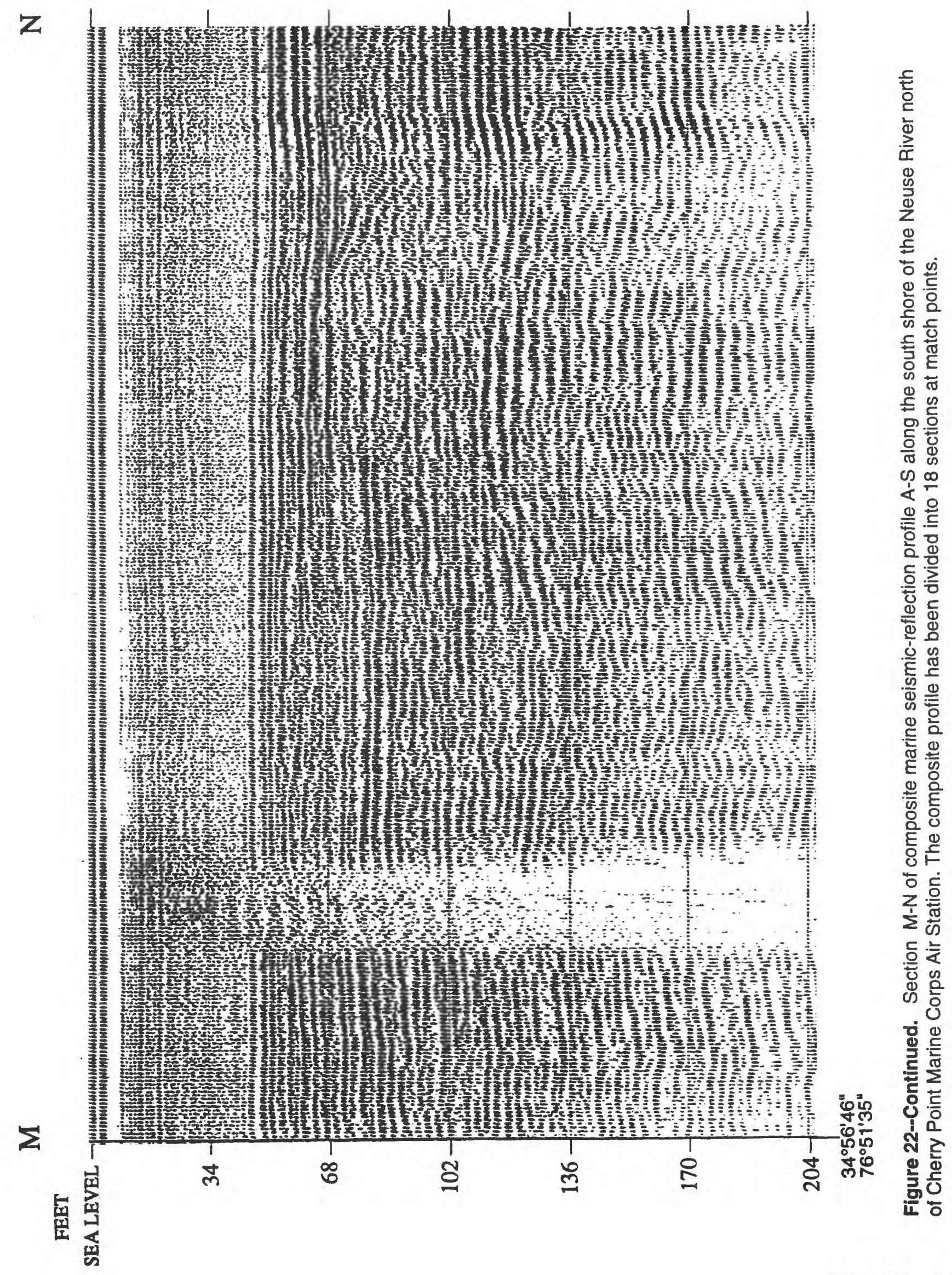

Figure $22 \quad 91$ 


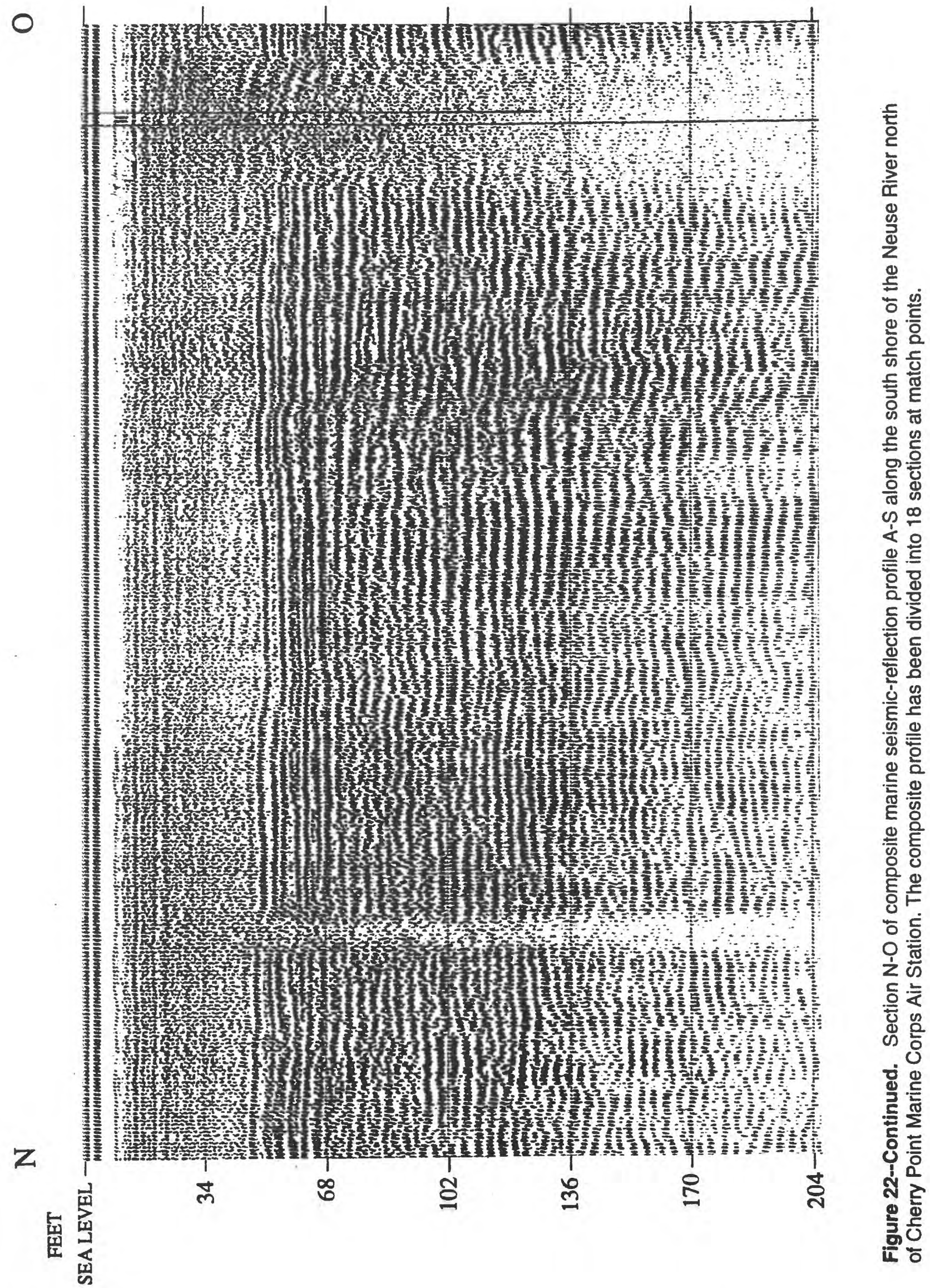




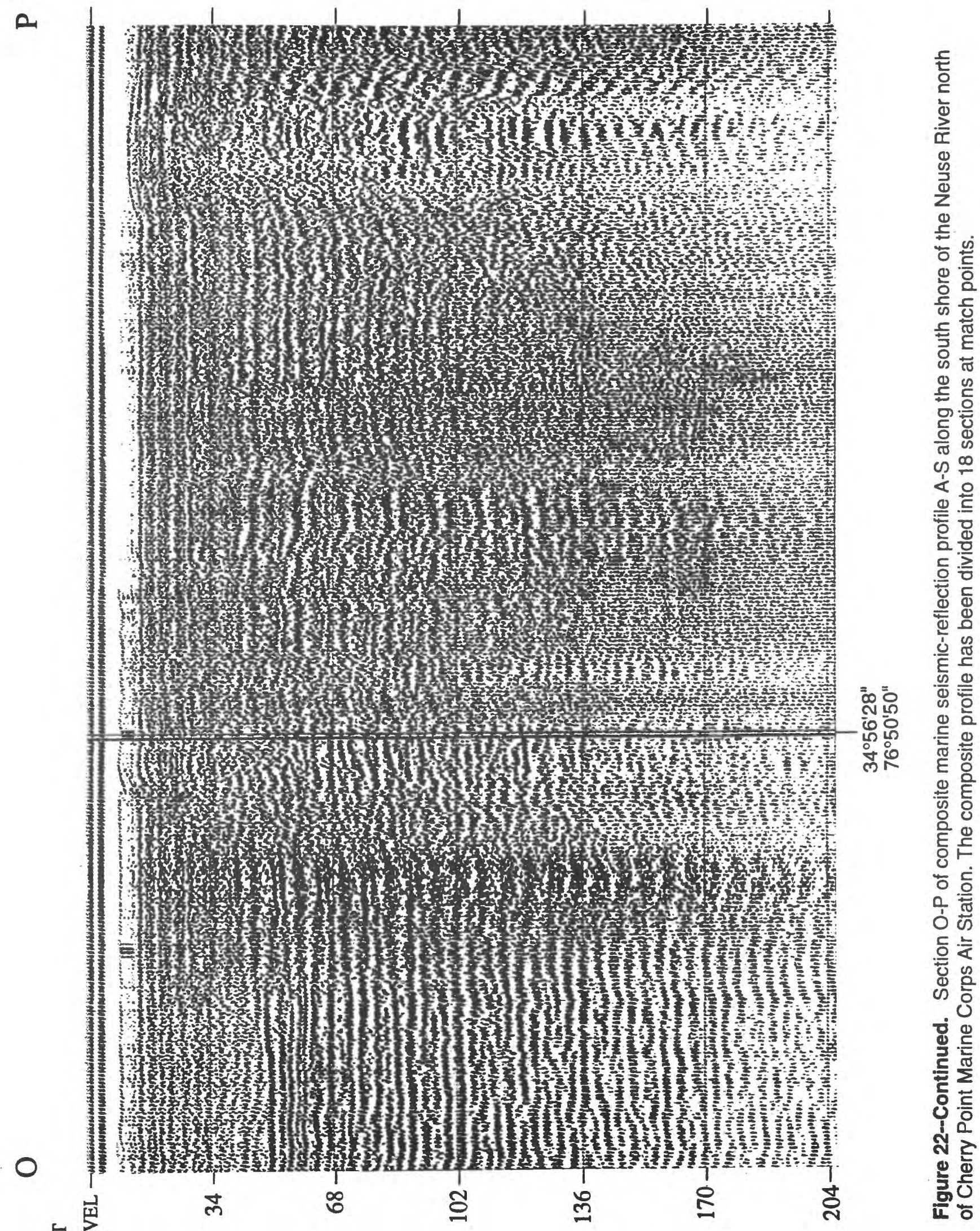




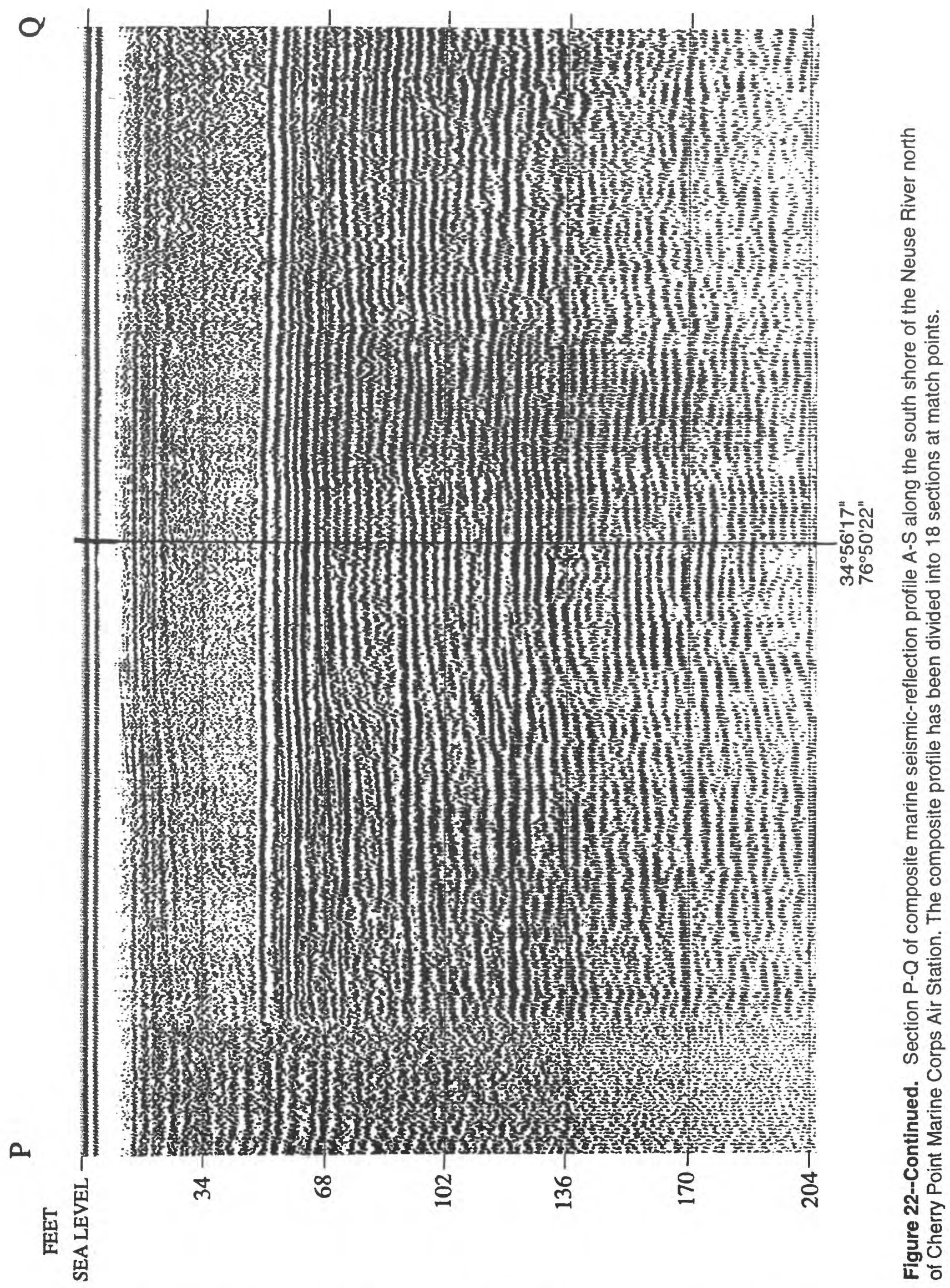




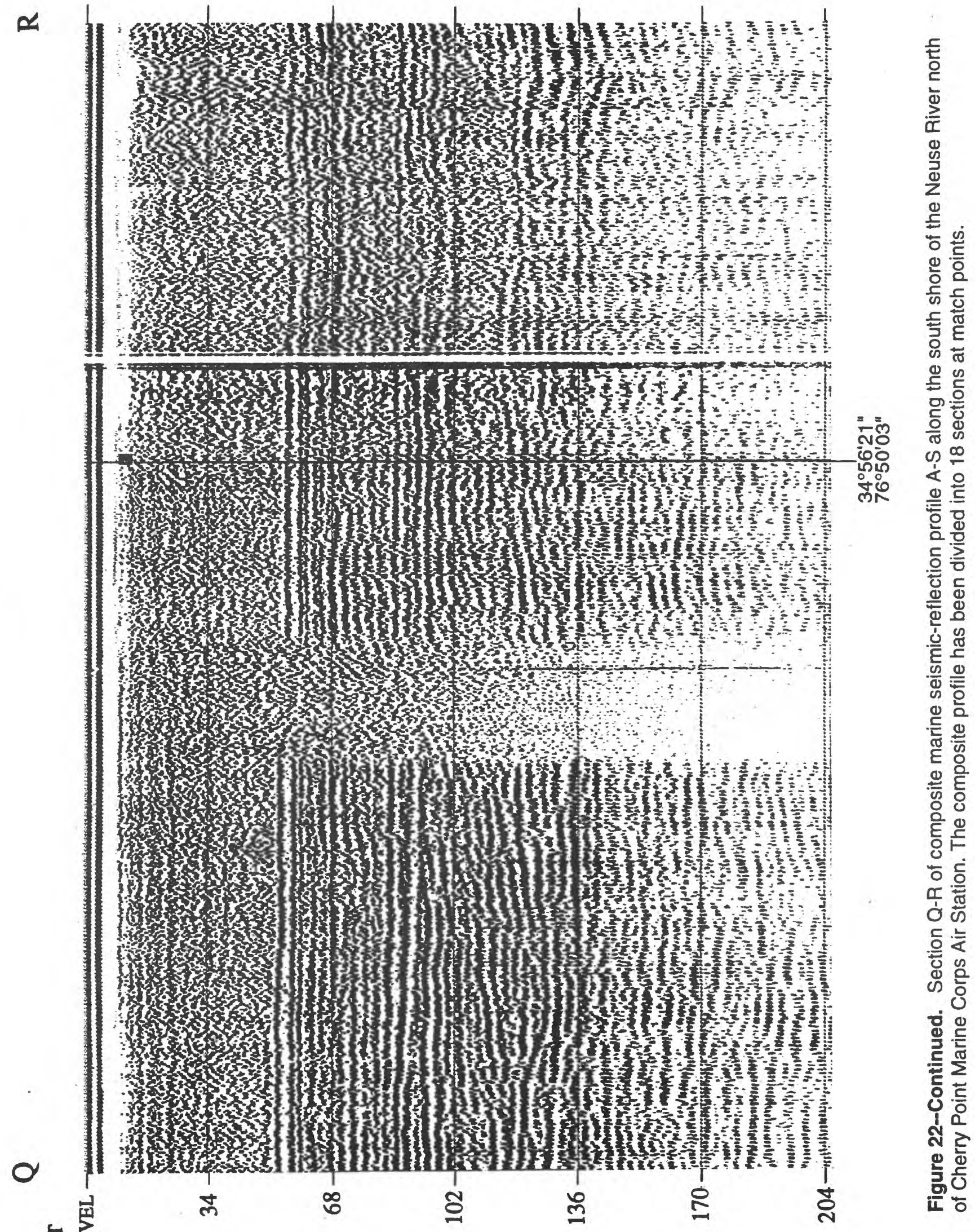




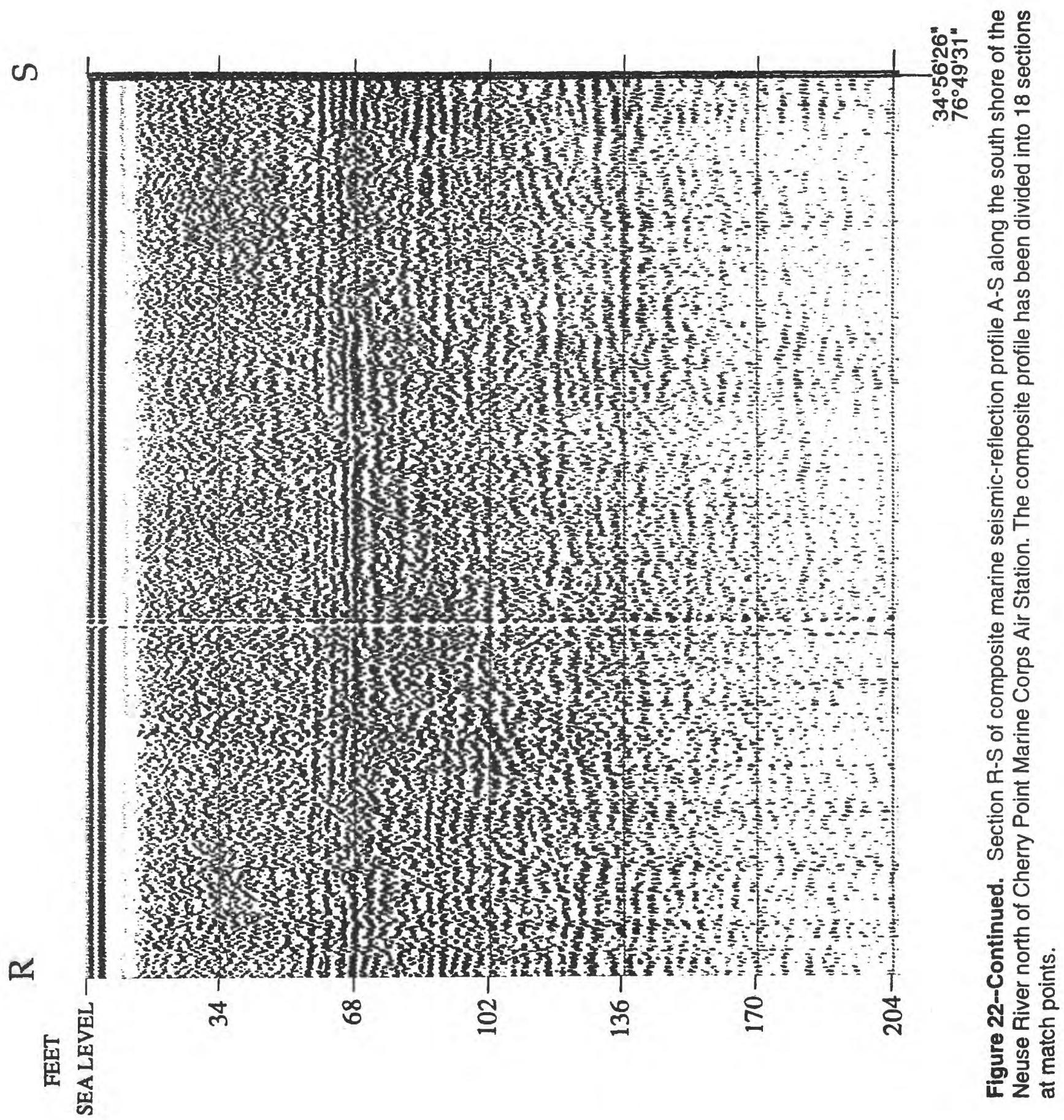


Table 2. Lithologic log for stratigraphic test well 1

\section{Description}

Depth below land

surface (feet)

SOIL

Silty CLAY

0-3

Silty, sandy CLAY

3-4

Fine SAND

4-5

No sample

$5-6$

SAND

6-8

8-10

Gray silty CLAY

10-12

Gray SAND, some silt

$12-14$

Well sorted fine SAND - light gray

$14-16$

Fine - medium SAND, clay ball

16-18

Fine silty, clayey SAND - light gray

$18-20$

CLAY stringers, coarse sand

20-22

Silty CLAY, coarse sand stringer

22-24

Medium-course SAND

24-26

Medium SAND, gray, well sorted, some silt

26-28

Fine-medium SAND, gray, well sorted, some silt

28-30

SAND, moderately indurated with silt and clay, light gray

$30-32$

SAND, gray clay and shall hash

32-34

Green-gray CLAY and shell fragments

$34-36$

Green-gray CLAY and shell fragments

$36-38$

Green-gray CLAY

$38-40$

Green CLAY - abundant shell hash

$40-42$

Bluish-gray SAND, medium to fine sand, phosphate grains, fine shell fragments, minor clay

$42-44$

Fine SAND, shell bits, modest clay, bluish gray

44-46

Fine SAND, fine shell bits, bluish gray

$46-48$

Fine SAND, bluish gray

$48-50$

Green silty CLAY, hard, some fine sand, fine shell fragments

$50-52$

Dense green silty CLAY, some fine sand, a few shell fragments

$52-54$

Dense green silty CLAY, few quartz grains

$54-56$

Green silty CLAY, a few polished quartz pebbles, 1-3 mm, phosphate pebbles, $1-2 \mathrm{~mm}$

$56-58$

Green silty clay with a few coarse quartz pebbles, 3-6 mm, color changes to gray

No sample, hard at bottom of interval, bit seizes, changed from drag bit to roller cone bit 
Table 2. Lithologic log for stratigraphic test well 1--Continued

\begin{tabular}{lc}
\hline \multicolumn{1}{c}{ Description } & $\begin{array}{c}\text { Depth below land } \\
\text { surface (feet) }\end{array}$ \\
\hline No sample, very hard & $60.9-61.7$ \\
No sample, soft, drills easy & $61.7-62$ \\
Dense green silty sandy CLAY & $62-63.3$ \\
Sand, clean fine gray & $63.3-64$ \\
No sample & $64-66$ \\
Fine (sugar) sand, clean, will sorted, no fossils & $66-67$ \\
No sample & $67-70$ \\
Fine SAND, clean, well sorted & $70-71.5$ \\
No sample & $71.5-74$ \\
Fine SAND, clean, well sorted & $74-75.5$ \\
No sample & $75.5-78$ \\
Fine SAND, greenish-gray color & $78-80$ \\
No sample & $80-82$ \\
Very fine greenish-gray SAND & $82-83.4$ \\
No sample & $83.4-86$ \\
Very fine gray SAND, a few shell fragments & $86-86.8$ \\
No sample & $86.8-90$ \\
Medium to coarse SAND, phosphate grains & $90-91.2$ \\
No sample & $91.2-94$ \\
Medium to coarse SAND, large phosphate and quartz pebbles, $4-8$ mm & \\
$\quad$ in diameter, abundant shell fragments & $94-95$ \\
Lime-cemented medium-to medium course sand & $95-96$ \\
No sample & $96-98$ \\
Fine SAND with a few shell fragments & $98-99.2$ \\
No sample & $99.2-102$ \\
Fine to medium limey SAND, with a few shell fragments, phosphate grains & $106-106.8$ \\
No sample & $104-106$ \\
SAND to coarse SAND, with limey phosphate grains & $106-106.8$ \\
No sample & $106.8-119.6$ \\
Fine silty SAND, gray shell fragments & $119.6-120.5$ \\
No sample & $120.5-135$ \\
Shell hash, about 50 percent of cuttings & $135-140$ \\
No sample & $140-150$ \\
Abundant shell fragments with limey brown clay, trace of limestone & $150-163$ \\
Boring terminated at 163 feet below land surface. & \\
\hline & \\
\hline & \\
\hline & \\
&
\end{tabular}


Table 3. Lithologic log for stratigraphic test well 2

\begin{tabular}{lc}
\hline \multicolumn{1}{c}{ Description } & $\begin{array}{c}\text { Depth below land } \\
\text { surface (feet) }\end{array}$ \\
\hline Organic SOIL with clay & $0-1$ \\
CLAY with fine sand, yellow & $1-2$ \\
Stiff CLAY, with medium sand, 20 percent sand & $2-3$ \\
CLAY with fine sand, 40 percent sand & $3-4$ \\
Dry SAND, fine with clay, well-sorted & $4-5$ \\
SAND, light brown & $5-7$ \\
Clean SAND, grading to more clays & $7-8$ \\
SAND, fine with clay, uniform & $8-10$ \\
SAND, fine to very fine, uniform & $10-12$ \\
SAND, fine, silty & $12-14$ \\
SAND, very fine to fine, clean & $14-16$ \\
SAND, fine, uniform, clean with trace medium & $16-18$ \\
SAND, fine to very fine, uniform, clean & $18-20$ \\
SAND, clean, fine, uniform & $20-22$ \\
Fine SAND, uniform, clean & $22-24$ \\
Clean, well graded, light gray quartz SAND & $23-24$ \\
Very fine SAND & $24-26$ \\
Very fine SAND & $26-28$ \\
Fine SAND, color change at bottom of interval & $28-30$ \\
Black, organic SAND & $30-31$ \\
SAND, course, well sorted & $31-32$ \\
Course SAND & $32-34$ \\
SAND, medium gray, with wood fragments & $34-38$ \\
SAND, medium, clean, sub-rounded, 30 percent white, black & \\
$\quad$ and gray shell fragments & $38-39$ \\
Shell fragments to 2 mm, clean, sandy, no clay & $39-40$ \\
$\quad$ clean sand and gravel, no more wood & $40-42$ \\
Nhells and sand, fine grading to course & $42-44$ \\
Slick green CLAY & $44-46$ \\
& $46-48$ \\
\hline
\end{tabular}


Table 3. Lithologic log for stratigraphic test well 2--Continued

\begin{tabular}{|c|c|}
\hline Description & $\begin{array}{l}\text { Depth below land } \\
\text { surface (feet) }\end{array}$ \\
\hline CLAY, dense, tight with shells and sand & $48-50$ \\
\hline SAND, medium to fine & $50-52$ \\
\hline SAND and shells, trace clay & $52-54$ \\
\hline Clayey SAND, trace shells & $54-56$ \\
\hline CLAY & $56-58$ \\
\hline CLAY & $58-59.5$ \\
\hline SILT & $59-5-60$ \\
\hline $\begin{array}{l}\text { Green CLAY, silty with course shells, gastropods and pelecypods, } \\
1-3 \mathrm{~mm} \text { phosphate pebbles }\end{array}$ & $60-62$ \\
\hline Green silty CLAY, a few shells, finer than above & $62-64$ \\
\hline Green clayey SILT & 64-64.8 \\
\hline Gray lime-cemented SAND & 64.8-66 \\
\hline Limey SAND, hard with small shells, some course sand & $66-68$ \\
\hline $\begin{array}{l}\text { Quartz and phosphate PEBBLES, } 2-10 \mathrm{~mm} \text {, with shell fragments, } \\
\text { pebbles well-rounded, sandy silt and green clay in last } 0.5 \text { feet }\end{array}$ & $68-70$ \\
\hline Green clayey SILT with small 1-3 mm quartz pebbles and shells & $70-72$ \\
\hline $\begin{array}{l}\text { Course limey SAND with a few pebbles and shell fragments, gray } \\
\text { with greenish tint, hard }\end{array}$ & $72-73.8$ \\
\hline $\begin{array}{l}\text { Abundant shell fragments, } 1-3 \mathrm{~mm} \text {, with greenish-gray sand and } \\
\text { minor clay }\end{array}$ & $74-76$ \\
\hline $\begin{array}{l}\text { Course sand and shell fragments, gray limey matrix, hard at top } \\
0.8 \mathrm{ft} \text { of interval }\end{array}$ & $76-78$ \\
\hline $\begin{array}{l}\text { Gray, course, limey sand and shell fragments, hard, changed to } \\
\text { roller bit }\end{array}$ & 78-78.9 \\
\hline Shell fragments, possible coquina layer & $79-82$ \\
\hline Same as above, with few phosphate grains & $82-84$ \\
\hline Same as above, very hard & 84.5 \\
\hline Same as above, softer & $84.5-88$ \\
\hline Green CLAY, no sand & $88-90$ \\
\hline Green sandy CLAY to green clay, no sand & $90-92$ \\
\hline Greenish-gray orthoquartzite (chert cement), & 92-92.8 \\
\hline Cemented SAND & 92-93.8 \\
\hline
\end{tabular}


Table 3. Lithologic log for stratigraphic test well 2--Continued

\begin{tabular}{lc}
\hline \multicolumn{1}{c}{ Description } & $\begin{array}{c}\text { Depth below land } \\
\text { surface (feet) }\end{array}$ \\
\hline CLAY & $93.8-96$ \\
SAND, fine, well-sorted, trace clay, (split spoon) & $96-98$ \\
SAND, fine with clay, green-gray & $98-100$ \\
Sandy CLAY, fine sand & $100-102$ \\
Same as above & $102-104$ \\
CLAY with sand, green, tight & \\
CLAY with very fine sand, green & $104-106$ \\
Same as above & $106-108$ \\
CLAY with very fine sand & $108-110$ \\
Green silty CLAY, with sand stringers, hard at 113.8 & $110-112$ \\
Green silty CLAY, with thin sand layers, quartz pebble 1-2 mm, & $112-113.8$ \\
$\quad$ small 1-1.5 mm plant fragment & $114-116$ \\
Same as above, with shells & $116-118$ \\
Same as above, with phosphate pebbles, 1-3 mm and 4-6 mm tan & \\
$\quad$ shale clast & $118-120$ \\
Green silty CLAY with abundant quartz and phosphate pebbles & \\
$\quad$ 1-4 mm, well-rounded, shell fragments & $120-122$ \\
No sample & $122-124$ \\
Fine SAND with hard, gray, clay balls & $124-125.2$ \\
No sample & $125.2-128$ \\
Very fine, gray, silty SAND & $128.4-129$ \\
No sample & $129-132$ \\
Shell fragments, soft limestone, (loss of drilling fluid to formation) & $132-133.3$ \\
Shell fragments, rounded quartz and phosphate grains to 2 mm & \\
\hline & \\
Boring terminated at 158 feet below land surface. & \\
\hline & \\
\hline
\end{tabular}


Table 4. Lithologic log for stratigraphic test well 3

\section{Description}

Tan, sandy SOIL

Gray CLAY, alternating with thin sand layers

Fine, well-sorted gray SAND

No sample

Dark gray CLAY and medium to course gray SAND layers

No sample

Dark gray CLAY and alternating yellow well-sorted SAND layers

No sample

Medium yellow SAND

No sample

Yellow-orange SAND, fine to medium, well-sorted with ochre stain, hard

No sample

Greenish-gray SAND to fine gray sand

Fine to course SAND, phosphate pellets

Very fine, well-sorted gray sand, very hard

No sample

Fine, well-sorted greenish-gray SAND

SAND with shell fragments

Fine gray SAND to light gray calcareous sand

Gray CLAY and shell fragments from 93-96 ft, abundant shell fragments

Light gray medium SAND, calcareous with shell fragments

Medium to course sand-sized SHELL fragments

Medium to course SAND with calcareous cement, some phosphate, light gray

Course SAND, phosphate grains and shell fragments, drills alternately hard and soft

No sample, drills hard

Course SAND, 2-3 mm, well-rounded, some phosphate grains, less shells than above

No sample, drills harder
Depth below land surface (feet)

$0-2$

3-10

$10-13$

13-20

20-22

$22-30$

30-32

$32-40$

40-42

42-50

50-52

55-60

60-62

62-70

70-71

71-80

80-82

82-90

90-91.7

91.7-100

100-102

102-110

$110-110.50$

110.5-113.7

113.7-114.5

114.5-119

119-120 
Table 4. Lithologic log for stratigraphic test well 3--Continued

\section{Description}

Cemented SAND, hard with shell fragments, grades to clean gray wellsorted fine sand

No sample

Fine, well-sorted gray SAND, no fossils

Shell fragments, clay balls, phosphate grains, quartz grains, and organic fragments

Fine gray well-sorted SAND with small, 3-6 mm, pebbles, hard

SHELL fragments

Very fine, clean gray SAND with heavy minerals

SAND, some shell fragments

SHELL fragments

Large SHELL fragments in greenish, silty, fine gray SAND matrix, switched to roller cone

No sample

Broken SHELL, balls of gray slick clay, phosphate grains

No sample

Fragments of phosphate and shell, quartz pebbles, 2-5 mm, a few dark gray clay balls

SHELL fragments, a few fragments of voidic limestone

No sample

LIMESTONE, sample from wash, almost entirely fragments of voidic limestone, a few shell fragments and a few quartz and phosphate pebbles 3-6 mm, well rounded

No sample

LIMESTONE, a few shell fragments

No sample

LIMESTONE, light tan and light gray voidic limestone

Boring terminated at 204 feet below land surface.
Depth below land surface (feet)

120-121.6

121.6-130

130-130.5

130.5-140

140-140.4

140.4-150

150-150.3

150.3-160

160-173.4

173.4-174.7

174.7-177

177-180

180-183

183-184.6

184.6-188

188-191

191-192

192-198

198-199

199-202

202-204 
Table 5. Lithologic log for stratigraphic test well 4

\begin{tabular}{|c|c|}
\hline Description & $\begin{array}{l}\text { Depth below land } \\
\text { surface (feet) }\end{array}$ \\
\hline Sandy, clayey organic top SOIL, grading to sandy clay trace gravel & $0-5$ \\
\hline Clayey SAND, with silt, brownish-gray & $5-10$ \\
\hline Sand to gravel, clayey, grayish-brown & $10-15$ \\
\hline Sand, gravel, clay, silty & $15-20$ \\
\hline Shells with clay, grayish-brown & $20-25$ \\
\hline Gray CLAY, some shells & $25-30$ \\
\hline Gray CLAY with a few shells & $30-35$ \\
\hline CLAY with shells & $30-37$ \\
\hline CLAY, with shell hash, olive green, trace ochre & $35-40$ \\
\hline Olive green CLAY, dry, green clay with white and gray shell hash & $45-48$ \\
\hline SAND with whitish clay stringers and some green clay with shells & $48-54$ \\
\hline Olive green SAND & $54-55$ \\
\hline SAND & $55-57$ \\
\hline Silty, sandy CLAY & $57-72.5$ \\
\hline Fine-grained SAND, heavy minerals, phosphate nodules & $72.5-79$ \\
\hline Dry, dark olive green CLAY & $79-82$ \\
\hline Clayey SAND with shell hash & $82-91$ \\
\hline Gray LIMESTONE with thin sand layers & $91-97$ \\
\hline Gray LIMESTONE with shells, trace clay & $97-100$ \\
\hline Gray SAND, trace heavy minerals & $100-102$ \\
\hline Gray CLAY, tight, stiff & $102-119$ \\
\hline Sandy CLAY, trace shells & $119.5-120.5$ \\
\hline CLAY & $120.5-122.5$ \\
\hline Very fine greenish-gray SAND, hard & $122-128.5$ \\
\hline Dark gray and whitish-gray SHELL layer & $128-129$ \\
\hline Cherty SHELL hash, poor recovery, hard & $128.5-131$ \\
\hline Silty SAND & $131-133$ \\
\hline CLAY & $133-134$ \\
\hline No sample, drills hard & $134-140$ \\
\hline Green-gray CLAY & $140-150$ \\
\hline Sandy CLAY, olive green & $150-151$ \\
\hline Very fine SAND & $151-152$ \\
\hline SHELL hash & $152-154$ \\
\hline SHELL hash, sandy & $154-160$ \\
\hline Dark gray SHELL hash, sandy, some clay & $160-170$ \\
\hline Dark gray SHELL hash, sandy, some clay & $170-180$ \\
\hline White LIMESTONE & $180-181.4$ \\
\hline LIMESTONE & $181.4-225$ \\
\hline
\end{tabular}


CONVERSION FACTORS, ABBREVIATIONS, ACRONYMS, TEMPERATURE, AND VERTICAL DATUM

\begin{tabular}{|c|c|c|}
\hline Multiply inch-pound unit & By & To obtain metric unit \\
\hline & Length & \\
\hline $\begin{array}{l}\text { inch (in) } \\
\text { foot }(\mathrm{ft}) \\
\text { mile (mi) }\end{array}$ & $\begin{array}{l}25.4 \\
0.3048 \\
1.609\end{array}$ & $\begin{array}{l}\text { millimeter }(\mathrm{mm}) \\
\text { meter }(\mathrm{m}) \\
\text { kilometer }(\mathrm{km})\end{array}$ \\
\hline mile (mi) & Area & \\
\hline square foot $\left(\mathrm{ft}^{2}\right)$ & 0.0929 & square meter $\left(\mathrm{m}^{2}\right)$ \\
\hline \multirow[t]{2}{*}{ square mile $\left(\mathrm{mi}^{2}\right)$} & 2.590 & square kilometer $\left(\mathrm{km}^{2}\right)$ \\
\hline & Volume & \\
\hline \multirow[t]{2}{*}{ gallon (gal) } & 3.785 & liter (L) \\
\hline & 0.003785 & cubic meter $\left(\mathrm{m}^{3}\right)$ \\
\hline \multirow[t]{2}{*}{ million gallon (Mgal) } & 3,785 & cubic meter $\left(\mathrm{m}^{3}\right)$ \\
\hline & Discharge & \\
\hline gallon per minute (gal/min) & 0.0000631 & cubic meter per second $\left(\mathrm{m}^{3} / \mathrm{s}\right)$ \\
\hline \multirow[t]{2}{*}{ million gallon per day (Mgal/d) } & 0.04381 & cubic meter per second $\left(\mathrm{m}^{3} / \mathrm{s}\right)$ \\
\hline & Velocity & \\
\hline $\begin{array}{l}\text { foot per second }(\mathrm{ft} / \mathrm{s}) \\
\text { foot per day }(\mathrm{ft} / \mathrm{d}) \\
\text { mile per hour }(\mathrm{mi} / \mathrm{h})\end{array}$ & $\begin{array}{l}0.3048 \\
0.3048 \\
1.609\end{array}$ & $\begin{array}{l}\text { meter per second }(\mathrm{m} / \mathrm{s}) \\
\text { meter per day }(\mathrm{m} / \mathrm{d}) \\
\text { kilometer per hour }(\mathrm{km} / \mathrm{h})\end{array}$ \\
\hline mile per hour $(\mathrm{mi} / \mathrm{h})$ & Mass & \\
\hline \multirow[t]{2}{*}{ pound (lb) } & 0.4536 & kilogram (kg) \\
\hline & Slope & \\
\hline \multirow[t]{2}{*}{ foot per mile $(\mathrm{ft} / \mathrm{mi})$} & 0.1894 & meter per kilometer $(\mathrm{m} / \mathrm{km})$ \\
\hline & Recharge & \\
\hline \multirow[t]{2}{*}{ inch per year (in/yr) } & 25.4 & millimeter per year $(\mathrm{mm} / \mathrm{yr})$ \\
\hline & Energy & \\
\hline calorie (cal) & 4.187 & joule $(J)$ \\
\hline
\end{tabular}




\section{ABBREVIATIONS USED IN THIS REPORT}

$\begin{array}{ll}\mathrm{dB} & \text { decibel } \\ \mathrm{Hz} & \text { Hertz } \\ \mathrm{mg} / \mathrm{L} & \text { milligram per liter } \\ \mathrm{ms} & \text { millisecond } \\ \mathrm{mv} & \text { millivolt }\end{array}$

\section{ACRONYMS USED IN THIS REPORT}

$\begin{array}{ll}\text { API } & \text { American Petroleum Institute } \\ \text { CDP } & \text { Common depth point } \\ \text { CMP } & \text { Common midpoint } \\ \text { CRP } & \text { Common reflection point } \\ \text { EAD } & \text { Environmental Affairs Department } \\ \text { GPS } & \text { Global positioning system } \\ \text { MCAS } & \text { Marine Corps Air Station } \\ \text { NADEP } & \text { Naval aviation depot } \\ \text { NMO } & \text { Normal moveout } \\ \text { QAVQC } & \text { Quality assurance/quality control } \\ \text { RASA } & \text { Regional aquifer system analysis } \\ \text { USGS } & \text { U.S. Geological Survey } \\ \text { USMC } & \text { U.S. Marine Corps } \\ \text { VSP } & \text { Vertical seismic profile }\end{array}$

\section{TEMPERATURE}

In this report, temperature is given in degrees Celsius $\left({ }^{\circ} \mathrm{C}\right)$, which can be converted to degrees Fahrenheit $\left({ }^{\circ} \mathrm{F}\right)$ by the following equation:

$$
{ }^{\circ} \mathrm{F}=1.8\left({ }^{\circ} \mathrm{C}\right)+32
$$

\section{SEA LEVEL}

In this report "sea level" refers to the National Geodetic Vertical Datum of 1929 (NGVD of 1929)--a geodetic datum derived from a general adjustment of the first-order nets of both the United States and Canada, formerly called Sea Level Datum of 1929. 